\title{
Cameroon: Fifth Review Under the Three-Year Arrangement Under the Poverty Reduction and Growth Facility, Financing Assurances Review, and Requests for Waiver of Performance Criterion, Modification of Performance Criteria and Extension of Arrangement_-Staff Report; Staff Supplement and Statement; Press Release on the Executive Board Discussion; and Statement by the Executive Director for Cameroon
}

In the context of the fifth review under the three-year arrangement under the Poverty Reduction and Growth Facility, financing assurances review, and requests for a waiver of a performance criterion, a modification of performance criteria and an extension of arrangement, the following documents have been released and are included in this package:

- $\quad$ The staff report for the Fifth Review Under the Three-Year Arrangement Under the Poverty Reduction and Growth Facility, Financing Assurances Review, and Requests for Waiver of Performance Criterion, Modification of Performance Criteria and Extension of Arrangement, prepared by a staff team of the IMF, following discussions that ended on April 23, 2008, with the officials of Cameroon on economic developments and policies. Based on information available at the time of these discussions, the staff report was completed on June 5, 2008. The views expressed in the staff report are those of the staff team and do not necessarily reflect the views of the Executive Board of the IMF.

- A staff supplement on the joint IMF/World Bank debt sustainability analysis.

- $\quad$ A staff statement of June 27, 2008, updating information on recent developments.

- $\quad$ A Press Release summarizing the views of the Executive Board as expressed during its June 27, 2008, discussion of the staff report that completed the review.

- A statement by the Executive Director for Cameroon.

The documents listed below have been or will be separately released.

Letter of Intent sent to the IMF by the authorities of Cameroon*

Memorandum of Economic and Financial Policies by the authorities of Cameroon*

Technical Memorandum of Understanding*

*Also included in Staff Report

The policy of publication of staff reports and other documents allows for the deletion of market-sensitive information.

Copies of this report are available to the public from

International Monetary Fund • Publication Services

$70019^{\text {th }}$ Street, N.W. • Washington, D.C. 20431

Telephone: (202) 623-7430 • Telefax: (202) 623-7201

E-mail: publications@imf.org・Internet: http://www.imf.org

Price: $\$ 18.00$ a copy

International Monetary Fund

Washington, D.C. 

INTERNATIONAL MONETARY FUND

\section{CAMEROON}

Fifth Review Under the Three-Year Arrangement Under the Poverty Reduction and Growth Facility, Financing Assurances Review, and Requests for Waiver of Performance Criterion, Modification of Performance Criteria and Extension of Arrangement

Prepared by the African Department

(In collaboration with other departments)

Approved by David Nellor and Adnan Mazarei

June 5, 2008

Discussions on the fifth review under the PRGF arrangement took place in Yaoundé February 28-March 13 and in Washington April 14-23. The mission met with Prime Minister Inoni, Finance Minister Menye, Economy Minister Motazé, and the acting National Director of the regional central bank (BEAC), Mr. Monayong. The team comprised Mr. Ghura (head), Mr. Ioannou, Mr. Singh (all AFR), Mr. Klemm (FAD), Mr. Gemayel (PDR), and Ms. Kabedi-Mbuyi, Resident Representative. Mr. Nyambal, Senior Advisor to the Executive Director for Cameroon, and World Bank staff participated in the discussions. 


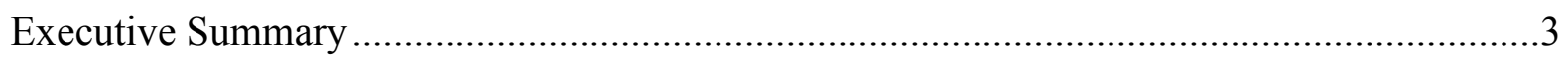

I. Background and Recent Economic Developments.........................................................

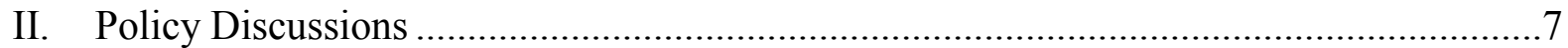

A. Safeguarding Fiscal Sustainability ...................................................................

B. Accelerating Growth and Private Sector Development .......................................11

III. Financing Assurances and Program Issues ...............................................................12

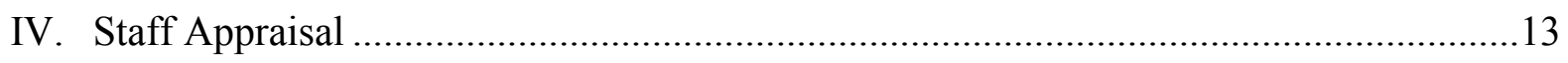

Boxes

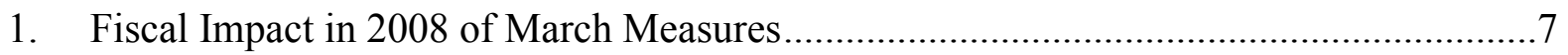

2. Fiscal Policy Considerations on Additional Spending …...............................................

Tables

1. Selected Economic and Financial Indicators, 2005-10 …….....................................14

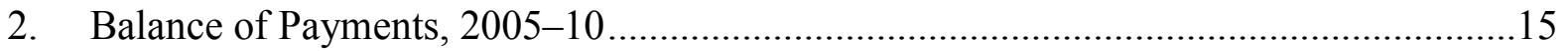

3. Monetary Survey, December 2005-December 2008 …….............................................16

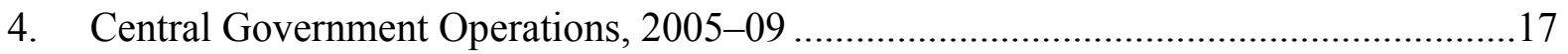

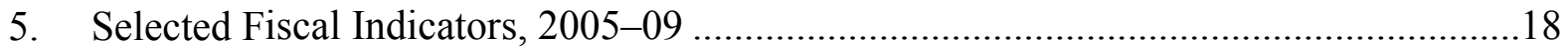

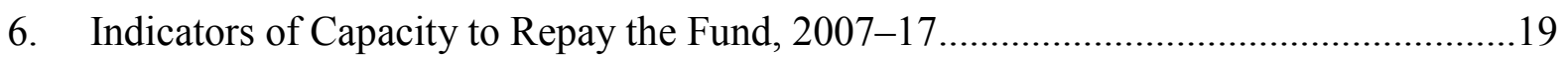

7. Fund Disbursements and Timing of Reviews Under the PRGF, 2005-08 .........................20

Appendix

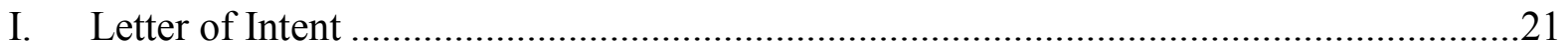

Attachment I. Memorandum of Economic and Financial Policies .................................23

Attachment II. Technical Memorandum of Understanding ............................................35 


\section{Executive Summary}

- Nonoil economic activity accelerated somewhat in 2007 and inflation declined. However, rising food and fuel prices starting in late 2007, amidst discussions of possible changes to the constitution, led to violent social unrest in February 2008.

- Program implementation was satisfactory in the second half of 2007. Most quantitative targets, notably on the nonoil primary fiscal deficit, for end-December 2007 were met. Nevertheless, the quantitative performance criterion related to domestic debt was missed by a narrow margin. Structural reforms proceeded satisfactorily.

- To address the rising living costs that triggered the social unrest, the authorities in March exempted some necessities from custom duties, froze fuel prices, and raised civil service salaries. These measures will raise the nonoil primary fiscal deficit relative to the baseline.

- Discussions focused on balancing the challenges of fiscal sustainability, addressing the social consequences of rising food and fuel prices, and promoting growth. Staff considers the course charted by the authorities to be consistent with these goals. In particular, staff welcomes the authorities' commitment to fiscal sustainability, including their determination to contain the budgetary effects of the March measures.

- Cameroon needs to strengthen policies to protect the poor from rising food and fuel prices by moving to more targeted assistance to vulnerable groups. It would also be important to resume the pass-through of fuel prices.

- To accelerate growth, Cameroon should intensify efforts to increase priority spending, including in agriculture and infrastructure. It should also improve the quality of spending and accelerate structural reform implementation. 


\section{Abbreviations and Acronyms}

CAMAIR

CAMPOST

CAMTEL

CET

CEMAC

EPA

FSAP

REER

SNEC

SONARA
Cameroon Airlines

Cameroon postal services

Cameroon telephone company

Common external tariff

Central African Economic and Monetary Community

Economic Partnership Agreement

Financial Sector Assessment Program

Real effective exchange rate

National water utility

National oil refinery 


\section{BACKGROUND AND RECENT ECONOMIC DEVELOPMENTS}

1. Security has improved since the February unrest. The turmoil was caused by dissatisfaction with the rising costs of food and fuel amidst discussions of possible changes to the constitution. In March the authorities adopted fiscal measures-exempting some necessities from custom duties, freezing fuel prices, and increasing civil service salariesthat helped improve security. In April, Parliament adopted constitutional amendments, one of which eliminated the two-term limit for presidents.

\section{Economic activity picked up in $\mathbf{2 0 0 7}$ and external developments were favorable} (Tables 1 and 2):

- Nonoil real GDP growth picked up as construction, agriculture, and forestry activity recovered.

- The external current account registered a small surplus, despite an increase in the volume of imports resulting from reduced taxation of basic staple goods.
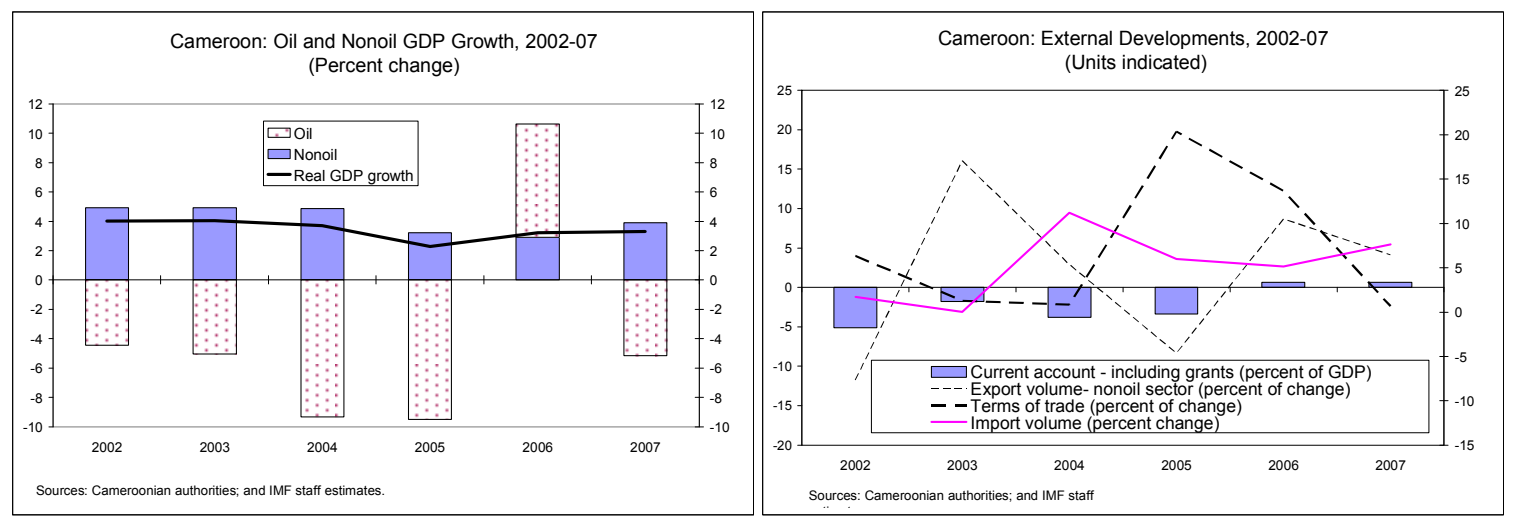


\section{Money growth increased in $\mathbf{2 0 0 7}$ but for most of the year inflation decelerated.}

Continued accumulation of net foreign assets and a slower pace of accumulation of government deposits in the banking system led to a rise in money growth (Table 3 ). Inflation declined, however, because of the partial pass-through of higher oil prices, lower taxation of staple goods, and the euro appreciation. At year-end, inflation headed up as food prices rose. The REER depreciated slightly despite the rise in the terms of trade.
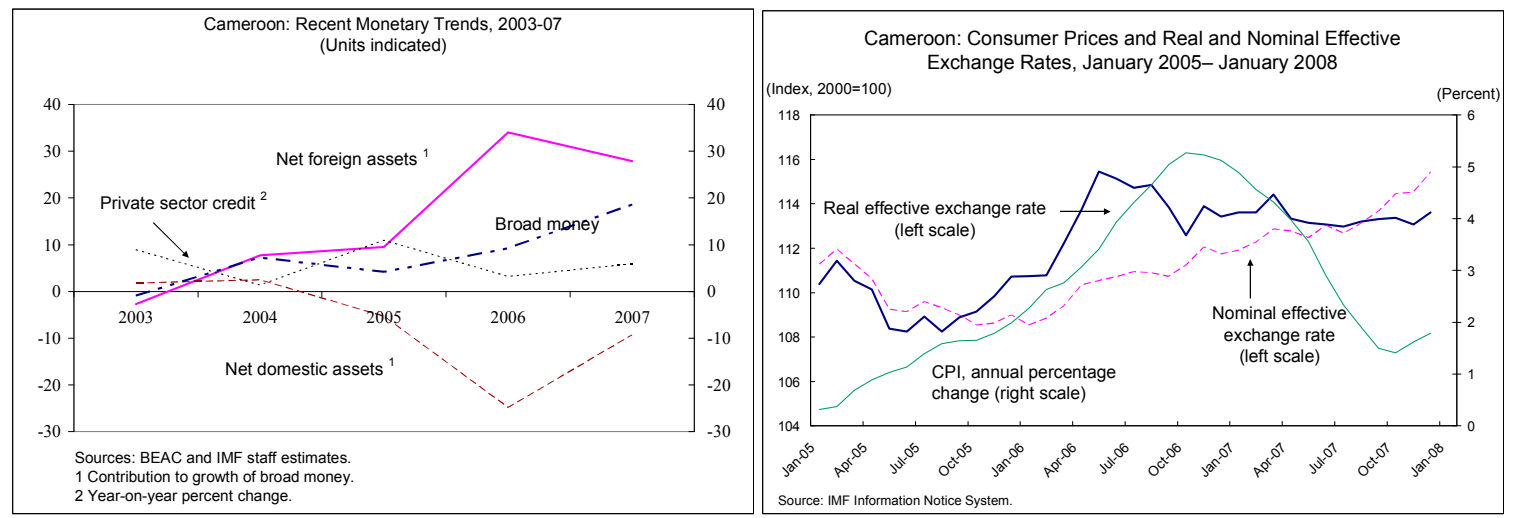

4. $\quad$ Fiscal performance in $\mathbf{2 0 0 7}$ was generally satisfactory. Capital spending was much higher than in 2006 as the authorities began to tackle bottlenecks to investment and donors raised disbursements. Nonoil revenues, however, stagnated in relation to nonoil GDP due to a shortfall in nontax revenues. Restraint on current spending and higher than expected oil revenues contributed to the fiscal surplus. Nonetheless, the stock of treasury float ${ }^{1}$ rose by about 0.3 percent of GDP in 2007, raising questions

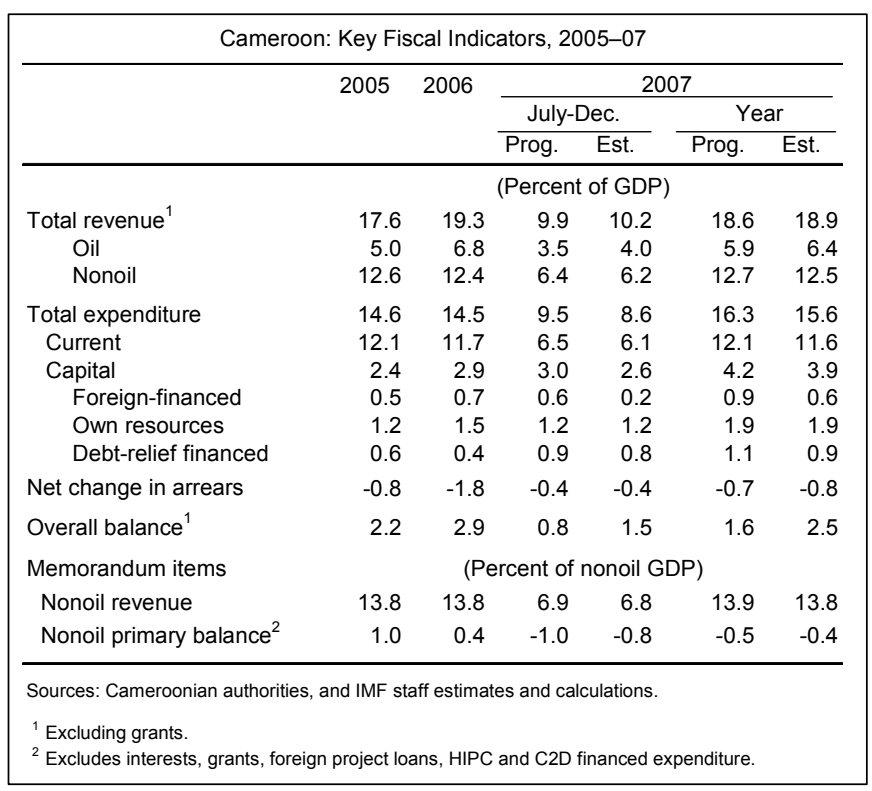
about public expenditure management.

\footnotetext{
${ }^{1}$ Difference between payment orders issued and cash payments.
} 


\section{Program implementation for July-December 2007 was satisfactory}

(MEFP, Tables 1-2):

- Most quantitative program targets for December 2007 were met. Nevertheless, the performance criterion related to domestic debt and the benchmark on nonoil revenues were missed by small margins.

- The planned structural reforms were completed, and Parliament approved the 2008 budget law. A new formula was adopted for automatic adjustment of fuel prices (performance criterion). The structural benchmark on streamlining taxpayer identification and safeguarding the single taxpayer file was met.

6. Reform of public enterprises is proceeding slowly. The management contract for SNEC was signed in December 2007, and the authorities have selected a privatization advisor for CAMAIR. Technical evaluation of bids on privatizing CAMTEL was completed, and the authorities are assessing next steps (MEFP, $₫ 6,36$ ).

\section{Policy Discussions}

\section{Implications of the recent unrest for policy choices and the macroeconomic} outlook dominated the discussions. The gross cost of the measures the government adopted is an estimated 1.6 percent of nonoil GDP for 2008 (Box 1). Staff noted that the fuel price freeze and adhoc tariff reductions were second best policy choices that could be accommodated as long as they remained temporary. Two policy challenges have gained urgency since the recent unrest: safeguarding medium-term fiscal sustainability, and accelerating growth and private sector development. The authorities will implement a twopronged approach to meeting these challenges. First, the tax exemption and fuel price freeze are to be temporary and will be reassessed in the context of the 2009 budget preparation, while simultaneously, measures will be taken to contain budgetary costs. Second, structural reforms and capital outlays will be accelerated to spur agriculture production and pro-poor growth.

\section{Box 1. Fiscal Impact of March 2008 Measures (Percent of nonoil GDP)}

0.7 percent: increase in civil service wages by 15 percent and adjustment of the housing allowance from 10 to 20 percent of basic salary.

$>\mathbf{0 . 3}$ percent: exemption of basic commodities (rice, wheat, palm and cooking oil, fish) from import taxes, and reduction in the external tariff on imported cement from 30 to 10 percent.

0.6 percent: fuel price freeze. 


\section{A. Safeguarding Fiscal Sustainability}

8. The medium-term fiscal strategy aims to create space for priority outlays while preserving fiscal sustainability. Using conservative oil price assumptions ${ }^{2}$ it targets (i) a gradual increase in nonoil revenues; (ii) expanded poverty-related spending; and (iii) paying down domestic arrears to improve the business environment. The authorities are committed to a path of fiscal sustainability and to building space for priority spending, particularly on agriculture and infrastructure. Staff sees room for higher outlays than in the baseline scenario (Box 2).

\section{Box 2. Fiscal Policy Considerations on Additional Spending}

- Higher public spending will contribute to higher growth and improved social conditions. Staff analysis shows room for additional spending of about 1 percent of GDP under a scenario in which current spending is financed by nonoil revenues and capital projects by oil revenues and debt.

- Higher spending would require closer attention to:

$\checkmark \quad$ Institutional capacity. Cameroon needs to continue (i) strengthening public expenditure tracking and training personnel accordingly; and (ii) improving capacity to prepare, evaluate, and execute projects. Capital projects would need to be carefully selected to maximize their growth impact. Furthermore, the authorities would need to strengthen debt management, including by finalizing their preliminary debt strategy, in order to contain future risks (MEFP, $\mid 27$ ).

$\checkmark$ Absorptive capacity. The inflationary impact of the proposed increase in spending would be modest because economic growth is below potential. Inflationary pressures arising from capital projects would be minimized if outlays were geared toward expanding productive capacity with high import content.

- The DSA results indicate that the revised macroeconomic forecast, including higher spending, is consistent with fiscal sustainability (Supplement).

9. The fiscal stance in $\mathbf{2 0 0 8}$ will be eased by about 1 percent of nonoil GDP relative to the baseline scenario. To contain the costs of the March fiscal measures, the authorities plan to cut spending on goods and services by 0.7 percent of nonoil GDP. Staff cautioned against deep cuts that might endanger government services. The authorities noted, however, that the bulk of the cuts originate from lower prices that have been renegotiated with suppliers, and assured staff that the savings can be achieved without jeopardizing services.

\footnotetext{
${ }^{2}$ Oil price projections are set below WEO prices by a constant prudence factor currently amounting to US\$7 dollars a barrel, in addition to a US\$3 dollar a barrel quality discount.
} 
The main changes to the fiscal program relative to the baseline scenario, necessitated by measures taken to address the population's grievances and the need to contain the costs, are that:

- Nonoil revenue will be lower because of the reduction of customs tariffs on essential staples and cement. Meanwhile, efforts to improve tax and customs administration will continue (MEFP $\llbracket 14)$.

- The current expenditure-to-GDP ratio will be higher by about 0.6 percentage point of GDP; higher spending on salaries and fuel subsidies will be partially offset by lower spending on goods and services.

- Fuel subsidies will be higher by 1.1 percentage point of GDP, because fuel prices are frozen for the rest of 2008 ( 0.6 percentage point of GDP) and a more transparent price formula is being introduced ( 0.5 percentage point of GDP). ${ }^{3}$ If oil prices increase beyond expectations, the authorities will adjust domestic prices, taking into account the social situation (MEFP, $ๆ 23$ ).

10. Fiscal policy will be somewhat more relaxed over the medium term than in the baseline scenario. By 2012, the nonoil primary fiscal balance (program definition) will be about 0.7 percent of nonoil GDP higher than programmed, which is consistent with fiscal sustainability.

- Nonoil revenue. The shortfall between projected and

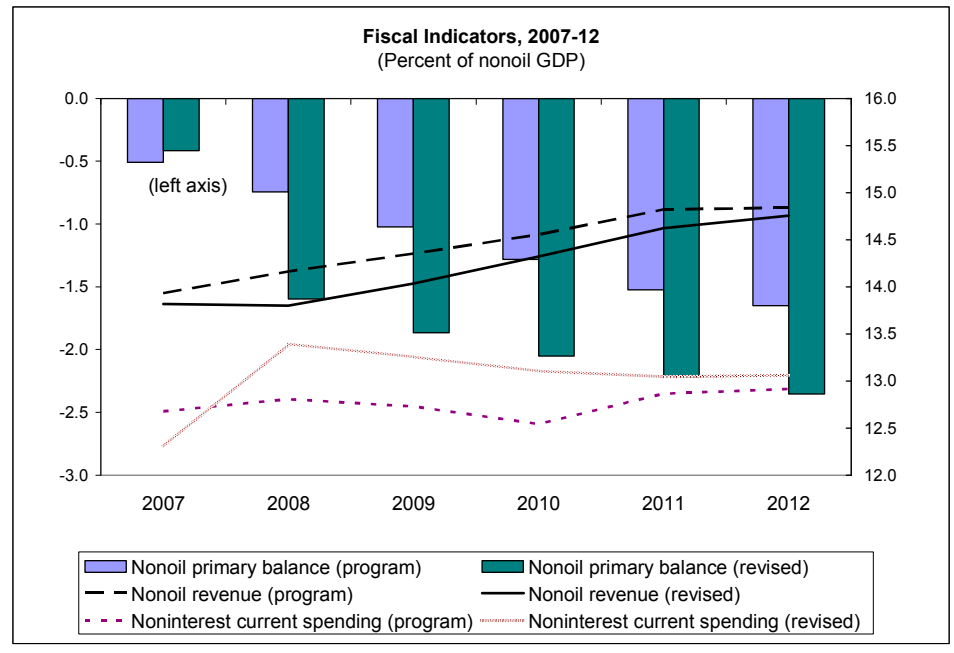
programmed nonoil revenues will be gradually reduced. The authorities agreed to adopt measures in the 2009 budget that would start nonoil revenues heading upward (MEFP, $\llbracket 14-15)$.

- Priority spending. The authorities plan to increase capital outlays on infrastructure and agriculture but also lower noninterest current spending. They are preparing programs to

\footnotetext{
${ }^{3}$ The formula, which adjusts fuel prices to reflect world market conditions, includes an allowance to cover SONARA's financial losses stemming from the less than full pass through and the refinery's inefficiency. The new formula replaces the support that was provided to SONARA through lower taxes by an explicit subsidy, with an equivalent increase in nonoil revenue collection (MEFP, $\mid 22$ ).
} 
boost food production and rural infrastructure. Efforts to contain the wage bill and reduce transfers to public enterprises will continue (MEFP, $\uparrow 19,36)$. They will also resume the pass-through of changes in world oil prices to consumers and reduce subsidies in favor of SONARA. Freed budgetary resources should be used to improve the social safety net. The authorities noted that putting in place a benefit system that targets the poor directly would take time and require technical assistance.

- Civil service reform. The authorities will continue working to secure the payroll and personnel systems. They will also undertake a diagnostic before designing a civil service reform strategy (MEFP, $\uparrow 19)$.

\section{The authorities agreed that public expenditure management needs further work.}

To strengthen medium-term expenditure planning, budget execution, and tracking, they are moving to prepare the fiscal operations table on a payment order basis. Meanwhile, they have agreed to set a ceiling on the stock of treasury floats (MEFP, \20). The new organic law, adopted in December 2007, aims at strengthening budget execution, accounting framework, and control rules. Staff urged the authorities to execute the new law cautiously, while simultaneously reinforcing implementation capacity.

\section{The revised}

macroeconomic framework reflects government priorities since the February unrest.

The main effects of the unrest and policy measures are as follows (Tables 1-5):

- Despite the turmoil's adverse impact on growth, nonoil oil GDP will grow by $4 \frac{1}{2}$ percent. The authorities are of the view that the 2007 growth momentum will continue, driven primarily by agriculture, services, and higher public investment.

\begin{tabular}{|c|c|c|c|c|c|}
\hline \multicolumn{6}{|c|}{$\begin{array}{l}\text { Cameroon: Selected Macroeconomic Indicators, 2007-09 } \\
\text { (Units indicated) }\end{array}$} \\
\hline & \multirow{2}{*}{$\begin{array}{r}2007 \\
\text { Est. }\end{array}$} & \multicolumn{2}{|c|}{ Program $^{1}$} & \multicolumn{2}{|c|}{ Updated Scenario } \\
\hline & & 2008 & 2009 & 2008 & 2009 \\
\hline \multicolumn{6}{|l|}{ Economic growth and prices } \\
\hline Real GDP ${ }^{2}$ & 3.3 & 4.4 & 4.6 & 4.5 & 4.6 \\
\hline Of which: nonoil & 3.9 & 4.5 & 4.9 & 4.6 & 4.8 \\
\hline Consumer prices (period average) ${ }^{2}$ & 0.9 & 3.3 & 2.0 & 4.1 & 2.5 \\
\hline Program oil price (U.S. dollars per barrel) & 69.6 & 65.0 & 59.3 & 102.0 & 106.3 \\
\hline Gross domestic investment ${ }^{3}$ & 17.4 & 19.4 & 20.0 & 17.7 & 19.1 \\
\hline \multicolumn{6}{|l|}{ Fiscal aggregates $^{3}$} \\
\hline Total revenue (excl. grants) & 18.9 & 18.4 & 18.5 & 20.6 & 21.4 \\
\hline Of which: nonoil ${ }^{4}$ & 13.8 & 14.2 & 14.4 & 14.3 & 14.6 \\
\hline Total expenditure & 15.6 & 17.3 & 17.9 & 17.5 & 17.9 \\
\hline Of which: noninterest current & 11.1 & 11.7 & 11.8 & 12.2 & 12.1 \\
\hline capital & 3.9 & 5.2 & 5.7 & 4.9 & 5.4 \\
\hline Overall budget balance (excl. grants) & 3.3 & 1.1 & 0.5 & 3.2 & 3.5 \\
\hline Of which: nonoil primary fiscal balance ${ }^{4,5}$ & -0.4 & -0.7 & -1.0 & -1.6 & -1.9 \\
\hline Overall budget balance (incl. grants) & 4.5 & 1.9 & 1.5 & 4.0 & 4.4 \\
\hline \multicolumn{6}{|l|}{ Balance of payments } \\
\hline Current account (excl. grants) ${ }^{3}$ & -0.6 & -3.1 & -3.6 & 0.8 & -0.3 \\
\hline Export volume $^{2}$ & 2.3 & 4.0 & 4.0 & 5.1 & 5.1 \\
\hline Of which: nonoil & 4.1 & 5.4 & 5.9 & 6.2 & 7.4 \\
\hline Import volume ${ }^{2}$ & 7.6 & 3.7 & 3.3 & 9.1 & 4.6 \\
\hline Of which: nonoil & 6.4 & 3.9 & 4.9 & 10.1 & 6.5 \\
\hline \multicolumn{6}{|c|}{ Sources: Cameroonian authorities; and IMF staff estimates and projections. } \\
\hline \multicolumn{6}{|l|}{ Based on Country Report No. 07/285. } \\
\hline \multirow{2}{*}{\multicolumn{6}{|c|}{ Percentage change. }} \\
\hline & & & & & \\
\hline \multicolumn{6}{|l|}{${ }^{4}$ Percent of nonoil GDP. } \\
\hline
\end{tabular}

- The reduction in import taxes and expected rise in imports should contain inflationary pressures.

- The external current account deficit will be smaller because oil exports are higher. Import volume will increase, however, because import taxes are lower. 


\section{B. Accelerating Growth and Private Sector Development}

13. To revive growth, the authorities recognize that the business environment needs to improve. They will continue to target areas identified in business surveys as core to attracting investment - developing the financial sector, opening trade, and improving transparency and governance.

\section{Financial sector}

14. Building on the new medium-term action plan, financial intermediation will be strengthened (MEFP, ๆ29-31). The plan proposes measures to create new financial products for small and medium enterprises, improve data collection, strengthen the supervision of microfinance, diversify financing instruments, and create specialized financial institutions. In addition, with a view to developing the securities market, the authorities will limit recourse to new statutory advances and issue publicly-traded government securities. They are also assessing the future financial activities of CAMPOST based on its new business plan (MEFP, ๆ33). With regard to specialized financial institutions, the staff noted that past public intervention in the financial sector had proved costly and ineffective. It urged the authorities instead to consider reforms to improve the operating environment (e.g., information flows, accounting standards, and the legal system). The authorities argued that dealing with the structural impediments to financial intermediation would take time, and a well-defined strategy could give the government a role in the interim.

\section{Trade}

15. Trade liberalization can expand growth opportunities. The medium-term revenue loss associated with the recently initialed EPA will likely be modest because liberalization will be phased in gradually and apply first to low-taxed goods. To minimize the risk of trade diversion, staff encouraged the authorities to pursue multilateral trade liberalization and deepen regional integration by harmonizing rules of origin and streamlining CET exemptions (MEFP, $\mid 28$ ). 


\section{Business environment}

16. To attract investment and revive growth, the business environment should be enhanced. The authorities recognize that progress has been slow; they agreed to work with the private sector to prepare a privatesector development strategy (MEFP, ๆ34).

\section{Transparency and governance}

\section{Continued efforts to improve} governance would reduce regulatory uncertainty (MEFP, $\mid 35$ ). The authorities

\begin{tabular}{|c|c|c|c|c|}
\hline \multicolumn{5}{|c|}{ Cameroon: Doing Business Indicators, $2007^{1}$} \\
\hline & $\begin{array}{r}\text { Doing } \\
\text { Business } \\
\text { (Overall }^{\text {rank) }}{ }^{1} \\
\end{array}$ & $\begin{array}{r}\text { Days to } \\
\text { acquire } \\
\text { licenses } \\
\end{array}$ & $\begin{array}{r}\text { Cost of } \\
\text { registering } \\
\text { property }\end{array}$ & $\begin{array}{r}\text { Days to } \\
\text { enforcing } \\
\text { contracts } \\
\end{array}$ \\
\hline Cameroon & 154 & 426 & 18 & 800 \\
\hline Philippines & 133 & 177 & 4 & 842 \\
\hline Indonesia & 123 & 196 & 11 & 570 \\
\hline China & 83 & 336 & 40 & 91 \\
\hline Botswana & 51 & 167 & 5 & 987 \\
\hline Mauritius & 27 & 107 & 11 & 750 \\
\hline Thailand & 15 & 156 & 0 & 54 \\
\hline CEMAC & 165 & 238 & 16 & 731 \\
\hline Sub-Saharan Africa & 136 & 262 & 11 & 643 \\
\hline LMIC $^{3}$ & 99 & 220 & 6 & 631 \\
\hline $\begin{array}{l}\text { Source: Doing Busin } \\
{ }^{1} \text { Indicates ranking o } \\
{ }^{2} \text { Percent of value. } \\
{ }^{3} \text { Lower-middle-incor }\end{array}$ & $\begin{array}{l}\text { tabase, } 200 \\
78 \text { countries } \\
\text { ntries. }\end{array}$ & $\begin{array}{l}8 \text { (World } \mathrm{B} \\
\text { (lower nun }\end{array}$ & $\begin{array}{l}\text { 3ank) } \\
\text { nber = higher }\end{array}$ & ranking). \\
\hline
\end{tabular}
recently stepped up their anticorruption efforts by arresting two ex-ministers on corruption charges. They will continue publishing corruption-related court decisions and prepare an anticorruption strategy based on a program developed with donors.

\section{Financing Assurances And Program Issues}

\section{Given Cameroon's arrears to private external creditors, the mission discussed} the issue of financing assurances. Staff reiterated the importance of reaching agreement with all commercial creditors, in line with Cameroon's commitments to the Paris Club. The authorities expect to finalize negotiations with the three remaining commercial creditors (holding claims of about US\$91 million) in 2008.

19. The main risks to the program have to do with fiscal sustainability and growth. Further unrest would test the authorities' willingness to withstand pressures to spend too much. Slower progress in mobilizing nonoil revenue and uncertainties about reductions in spending on goods and services could also undermine medium-term fiscal objectives. Insufficient improvement in the business environment and poor capital budget execution could jeopardize growth and poverty reduction.

20. The program is monitored twice a year. ${ }^{4}$ Considering the impact of measures adopted to address popular concerns, the authorities have requested modification of performance criteria and benchmarks for June (MEFP, Table 1). They have also included an indicative target on the stock of treasury floats to reinforce budget management. Since the current arrangement expires in October, they have requested an extension until January 2009 to allow time for completion of the sixth and final review.

\footnotetext{
${ }^{4}$ The last Annual Progress Report of the PRSP and the accompanying JSAN were submitted to the Board in December 2007.
} 


\section{Staff APPRAisal}

21. The government faces the challenge of balancing fiscal sustainability through prudent fiscal policy, addressing the harmful social consequences of rising food and fuel prices, and promoting growth through structural reforms and public investment. Staff believes that the course charted by the authorities, including measures adopted in March in response to the social unrest, is consistent with these goals. Nonetheless, staff sees several areas where policies need to be refined to maintain this balance among these goals.

22. Staff is encouraged by the authorities' commitment to fiscal sustainability. The increase in the nonoil primary fiscal deficit under the revised scenario is consistent with a sustainable fiscal path. Nonetheless, while welcoming the authorities' commitment to contain the budgetary impact of the March measures, staff cautions that cuts in spending on goods and services should not jeopardize public services. Also, the authorities will need to be vigilant with regard to institutional capacity constraints to higher spending. In this regard, the government needs to continue strengthening public expenditure management and improve its capacity to prepare and execute projects.

\section{Cameroon needs to strengthen policies to protect the poor from rising food and}

fuel prices. It will be important for fuel prices to reflect world market conditions so that consumption can adjust accordingly. Targeted support for the vulnerable groups (e.g., cash or in-kind transfers) is preferable to generalized subsidies as the latter tend to benefit the rich more than the poor. Ad hoc tariff reductions on food items could hurt incentives for local production, and thus should be limited in time.

24. Staff urges the authorities to intensify efforts to accelerate growth. There is scope for expanding fiscal space for increasing priority spending, including on agriculture and infrastructure, through mobilization of additional nonoil revenues and reduction of support to public enterprises. In addition, concrete measures will need to be implemented to improve financial intermediation, trade, and the business environment.

25. Debt policies should continue to be prudent. While the risk of debt distress remains low, the authorities should continue to borrow on concessional terms and make effective use of borrowed resources. Cameroon is making good faith efforts to reach understandings with commercial creditors, and developments in this area are not interfering with the country's adjustment efforts.

26. Staff recommends that the Board (i) complete the fifth review under the PRGF arrangement; (ii) grant a waiver for the nonobservance of the performance criterion related to domestic debt given that the target was missed only by a small margin, (iii) modify the June performance criteria to account for the fiscal impact of policies adopted to address the social consequences of rising food prices; (iv) extend the PRGF arrangement through January 2009; and (v) complete the financing assurances review. 
Table 1. Cameroon: Selected Economic and Financial Indicators, 2005-10

\begin{tabular}{|c|c|c|c|c|c|c|c|c|}
\hline & \multirow[t]{2}{*}{2005} & \multirow{2}{*}{$\frac{2006}{\text { Est. }}$} & \multicolumn{2}{|c|}{2007} & \multicolumn{2}{|c|}{2008} & \multirow{2}{*}{$\begin{array}{c}2009 \\
\text { Proj. }\end{array}$} & \multirow{2}{*}{$\frac{2010}{\text { Proj. }}$} \\
\hline & & & Prog. & Est. & Prog. & Proj. & & \\
\hline & \multicolumn{8}{|c|}{ (Annual percentage changes, unless otherwise indicated) } \\
\hline \multicolumn{9}{|l|}{ National income and prices } \\
\hline GDP at constant prices & 2.3 & 3.2 & 2.7 & 3.3 & 4.4 & 4.5 & 4.6 & 4.8 \\
\hline Oil & -9.5 & 7.7 & -7.5 & -5.2 & 2.4 & 2.4 & 0.9 & -1.9 \\
\hline Nonoil & 3.2 & 2.9 & 3.4 & 3.9 & 4.5 & 4.6 & 4.8 & 5.2 \\
\hline GDP deflator & 2.6 & 3.9 & 1.8 & 2.0 & 2.0 & 5.7 & 1.1 & 1.1 \\
\hline Consumer prices (12-month average) & 2.0 & 5.1 & 1.5 & 0.9 & 3.3 & 4.1 & 2.5 & 2.0 \\
\hline Nominal GDP (billions of CFA francs) & 8,750 & 9,388 & 9,812 & 9,894 & 10,443 & 10,929 & 11,560 & 12,242 \\
\hline Oil & 734 & 955 & 841 & 948 & 870 & 1,356 & 1,396 & 1,328 \\
\hline Nonoil & 8,016 & 8,433 & 8,971 & 8,946 & 9,573 & 9,573 & 10,164 & 10,914 \\
\hline Oil output (thousands of barrels a day) & 82 & 87 & 84 & 86 & 85 & 88 & 85 & 84 \\
\hline \multicolumn{9}{|l|}{ External trade } \\
\hline Export volume & -8.2 & 8.1 & 2.8 & 2.3 & 4.0 & 5.1 & 5.1 & 4.7 \\
\hline Of which: Nonoil sector & -8.3 & 8.7 & 5.1 & 4.1 & 5.4 & 6.2 & 7.4 & 6.4 \\
\hline Import volume & 6.0 & 5.1 & 9.6 & 7.6 & 3.7 & 9.1 & 4.6 & 4.2 \\
\hline Average oil export price (U.S. dollars per barrel) & 50.4 & 61.6 & 62.8 & 69.6 & 65.0 & 102.0 & 106.3 & 104.0 \\
\hline Nominal effective exchange rate & -4.4 & 3.2 & $\ldots$ & 2.6 & $\ldots$ & $\ldots$ & $\ldots$ & .. \\
\hline Real effective exchange rate & -3.5 & 4.5 & $\ldots$ & -0.7 & $\ldots$ & $\ldots$ & $\ldots$ & .. \\
\hline Terms of trade & 19.8 & 12.3 & -6.1 & -2.4 & -3.1 & 15.7 & -3.8 & -6.0 \\
\hline Nonoil export price index (CFA francs) & 8.5 & 11.3 & -1.5 & -3.1 & -2.5 & -3.9 & -4.5 & -1.7 \\
\hline \multicolumn{9}{|l|}{ Money and credit (end of period) } \\
\hline Net domestic assets ${ }^{1}$ & -5.3 & -24.8 & -8.1 & -9.3 & -4.7 & -15.3 & -17.9 & -18.5 \\
\hline Net credit to the public sector ${ }^{1}$ & -8.7 & -21.7 & -9.6 & -11.7 & -8.0 & -17.4 & -20.3 & -20.9 \\
\hline Credit to the private sector & 10.9 & 3.2 & 3.0 & 5.9 & 6.5 & 5.2 & 5.5 & 5.4 \\
\hline Broad money (M2) & 4.2 & 9.3 & 3.7 & 18.6 & 7.2 & 10.9 & 3.6 & 2.8 \\
\hline Velocity (GDP/average M2) & 5.9 & 5.8 & 5.7 & 5.3 & 5.8 & 5.4 & 5.5 & 5.7 \\
\hline \multicolumn{9}{|l|}{ Central government operations } \\
\hline Total revenue & 21.8 & 17.1 & 1.2 & 3.3 & 7.4 & 25.7 & 9.8 & 4.5 \\
\hline Of which: Nonoil revenue & 17.3 & 5.5 & 7.3 & 6.1 & 6.7 & 7.9 & 7.9 & 9.5 \\
\hline \multirow[t]{2}{*}{ Total expenditure } & -4.0 & 6.8 & 17.1 & 12.9 & 6.8 & 12.6 & 8.6 & 7.7 \\
\hline & \multicolumn{8}{|c|}{ (Percent of GDP, unless otherwise indicated) } \\
\hline Gross national savings & 15.7 & 17.5 & 17.0 & 17.8 & 17.2 & 19.5 & 19.7 & 19.4 \\
\hline Gross domestic investment & 19.1 & 16.8 & 18.4 & 17.4 & 19.4 & 17.7 & 19.1 & $19 . c$ \\
\hline \multicolumn{9}{|l|}{ Central government operations } \\
\hline Total revenue (excluding grants) & 17.6 & 19.3 & 18.6 & 18.9 & 18.4 & 20.6 & 21.4 & 21.1 \\
\hline Oil revenue & 5.0 & 6.8 & 5.9 & 6.4 & 5.4 & 8.1 & 8.6 & 7.9 \\
\hline Nonoil revenue & 12.6 & 12.4 & 12.7 & 12.5 & 13.0 & 12.5 & 12.8 & 13.2 \\
\hline Nonoil revenue (percent of nonoil GDP) & 13.8 & 13.8 & 13.9 & 13.8 & 14.2 & 14.3 & 14.6 & 14.8 \\
\hline Total expenditure & 14.6 & 14.5 & 16.3 & 15.6 & 17.3 & 17.5 & 17.9 & 18.2 \\
\hline Noninterest expenditure ${ }^{2}$ & 12.6 & 12.6 & 14.6 & 14.0 & 15.2 & 15.4 & 16.0 & 16.3 \\
\hline Capital expenditure ${ }^{3}$ & 2.3 & 2.6 & 3.9 & 3.5 & 4.7 & 4.5 & 5.2 & 5.6 \\
\hline \multicolumn{9}{|l|}{ Fiscal balance (excluding net changes in arrears) } \\
\hline Excluding grants & 3.0 & 4.7 & 2.4 & 3.3 & 1.1 & 3.2 & 3.5 & 2.9 \\
\hline Including grants & 3.6 & 33.1 & 3.9 & 4.5 & 1.9 & 4.0 & 4.4 & 3.6 \\
\hline Primary balance ${ }^{4}$ & 5.0 & 6.3 & 3.7 & 4.4 & 2.8 & 4.8 & 5.2 & 4.7 \\
\hline Nonoil primary balance (percent of nonoil GDP) ${ }^{4}$ & 0.0 & -0.6 & -2.4 & -2.2 & -2.9 & -3.7 & -3.9 & -3.6 \\
\hline \multicolumn{9}{|l|}{ External sector } \\
\hline Current account balance (including grants) & -3.4 & 0.7 & -1.4 & 0.4 & -2.2 & 1.7 & 0.5 & -0.5 \\
\hline Gross official reserves (months of imports) & 2.7 & 4.1 & 4.2 & 5.7 & 5.1 & 7.5 & 9.1 & 10.5 \\
\hline Stock of external debt ${ }^{5}$ & 36.7 & 5.5 & 6.2 & 5.5 & 7.2 & 6.1 & 6.1 & 6.1 \\
\hline Stock of public debt & 51.5 & 15.5 & 13.3 & 12.4 & 12.5 & 10.3 & 11.2 & 11.8 \\
\hline & & rcent of ex & orts of go & Is and se & ices, unles & sotherwis & indicated) & \\
\hline NPV of external debt after HIPC, bilateral relief beyond HIPC, and MDRI ${ }^{6}$ & 11.0 & 16.1 & 16.9 & 16.1 & 20.0 & 16.1 & 18.8 & 21.2 \\
\hline External debt service $^{7}$ & 6.7 & 3.3 & 1.4 & 1.0 & 1.5 & 1.0 & 1.1 & 1.0 \\
\hline External debt service (as a percent of government revenue) ${ }^{7}$ & 9.2 & 4.5 & 2.4 & 2.2 & 2.6 & 2.0 & 2.0 & 1.8 \\
\hline
\end{tabular}

Sources: Cameroonian authorities; and IMF staff estimates and projections.

1 Percent of broad money at the beginning of the period.

${ }^{2}$ Excluding foreign-financed investment, restructuring expenditure, and separation grants.

${ }^{3}$ Excluding restructuring expenditure.

${ }^{4}$ Excluding grants, interest, and foreign-financed capital expenditures.

${ }^{5}$ Assumes cancellation of C2D debt in 2006.

${ }^{6} \mathrm{NPV}$ s calculated using the LIC DSA methodology.

${ }^{7}$ Actual payments through 2006, and after all expected debt relief thereafter. 
Table 2. Cameroon: Balance of Payments, 2005-10

\begin{tabular}{|c|c|c|c|c|c|c|c|c|}
\hline & \multirow{2}{*}{2005} & \multirow{2}{*}{$\begin{array}{c}2006 \\
\text { Est. }\end{array}$} & \multicolumn{2}{|c|}{2007} & \multicolumn{2}{|c|}{2008} & \multirow{2}{*}{$\frac{2009}{\text { Proj. }}$} & \multirow{2}{*}{$\frac{2010}{\text { Proj. }}$} \\
\hline & & & Prog. & Est. & Prog. & Proj. & & \\
\hline & \multicolumn{8}{|c|}{ (Billions of CFA francs) } \\
\hline Current account balance & -294 & 62 & -137 & 41 & -228 & 187 & 59 & -59 \\
\hline Trade balance & 23 & 284 & 14 & 157 & -41 & 411 & 348 & 226 \\
\hline Exports, f.o.b. & 1,547 & 1,932 & 1,819 & 1,941 & 1,850 & 2,338 & 2,374 & 2,354 \\
\hline Oil and oil products & 763 & 983 & 893 & 984 & 899 & 1,360 & 1,371 & 1,305 \\
\hline Nonoil sector & 784 & 949 & 925 & 958 & 951 & 978 & 1,002 & 1,049 \\
\hline Imports, f.o.b. & $-1,524$ & $-1,648$ & $-1,805$ & $-1,784$ & $-1,891$ & $-1,927$ & $-2,025$ & $-2,128$ \\
\hline Services (net) & -188 & -222 & -297 & -265 & -354 & -275 & -341 & -369 \\
\hline Income (net) & -243 & -131 & -51 & -38 & -28 & -148 & -163 & -137 \\
\hline Of which: Interest due on public debt & -112 & -73 & -37 & -37 & -32 & -30 & -28 & -25 \\
\hline Transfers (net) & 114 & 132 & 198 & 187 & 195 & 199 & 215 & 223 \\
\hline Capital and financial account balance & 208 & 318 & 328 & 400 & 440 & 345 & 427 & 557 \\
\hline Capital account & 6 & 2,610 & 39 & 39 & 11 & 11 & 11 & 10 \\
\hline Capital transfers & 6 & 157 & 23 & 23 & 11 & 11 & 11 & 10 \\
\hline Debt forgiveness & 0 & 2,452 & 16 & 16 & 0 & 0 & 0 & 0 \\
\hline Financial account & 202 & $-2,291$ & 289 & 361 & 429 & 335 & 417 & 547 \\
\hline Official capital & -236 & $-2,558$ & 0 & -21 & 102 & 102 & 97 & 134 \\
\hline Private capital (net) & 438 & 267 & 289 & 382 & 327 & 233 & 320 & 412 \\
\hline Overall balance & -86 & 380 & 191 & 441 & 212 & 532 & 486 & 498 \\
\hline Financing & 86 & -380 & -191 & -441 & -212 & -532 & -486 & -498 \\
\hline Bank of Central African States & -140 & -475 & -191 & -441 & -212 & -532 & -486 & -498 \\
\hline Use of IMF credit (net) & -19 & -137 & 6 & 4 & 4 & 5 & 0 & 0 \\
\hline Use of Fund credit & -19 & -137 & 6 & 4 & 4 & 5 & 0 & 0 \\
\hline Other reserves (net) & -121 & -338 & -197 & -445 & -216 & -537 & -486 & -498 \\
\hline Exceptional financing (debt relief) & 237 & 89 & 0 & 0 & 0 & 0 & 0 & 0 \\
\hline Net change in arrears & -11 & 3 & 0 & 0 & 0 & 0 & 0 & 0 \\
\hline Financing need & 0 & 2 & 0 & 0 & 0 & 0 & 0 & 0 \\
\hline \multirow[t]{2}{*}{ Remaining financing gap } & 0 & 2 & 0 & 0 & 0 & 0 & 0 & 0 \\
\hline & \multicolumn{8}{|c|}{ (Percent of GDP) } \\
\hline Trade balance & 0.3 & 3.0 & 0.1 & 1.6 & -0.4 & 3.8 & 3.0 & 1.8 \\
\hline \multicolumn{9}{|l|}{ Current account balance } \\
\hline Excluding grants & -3.8 & 0.1 & -2.6 & -0.6 & -3.1 & 0.8 & -0.3 & -1.1 \\
\hline Including grants & -3.4 & 0.7 & -1.4 & 0.4 & -2.2 & 1.7 & 0.5 & -0.5 \\
\hline Overall balance & -1.0 & 4.1 & 2.0 & 4.5 & 2.0 & 4.9 & 4.2 & 4.1 \\
\hline & \multicolumn{8}{|c|}{ (Percentage change, unless otherwise indicated) } \\
\hline Export volume & -8.2 & 8.1 & 2.8 & 2.3 & 4.0 & 5.1 & 5.1 & 4.7 \\
\hline Oil sector & -7.9 & 6.4 & -4.1 & -3.3 & -1.0 & 1.4 & -3.0 & -2.1 \\
\hline Nonoil sector & -8.3 & 8.7 & 5.1 & 4.1 & 5.4 & 6.2 & 7.4 & 6.4 \\
\hline Import volume & 6.0 & 5.1 & 9.6 & 7.6 & 3.7 & 9.1 & 4.6 & 4.2 \\
\hline Of which: Nonoil sector & 4.7 & 0.8 & 8.5 & 6.4 & 3.9 & 10.1 & 6.5 & 4.3 \\
\hline Terms of trade & 19.8 & 12.3 & -6.1 & -2.4 & -3.1 & 15.7 & -3.8 & -6.0 \\
\hline Nonoil export price index (CFA francs) & 8.5 & 11.3 & -1.5 & -3.1 & -2.5 & -3.9 & -4.5 & -1.7 \\
\hline Import price index (CFA francs) & 3.3 & 2.9 & 0.3 & 0.6 & 1.0 & -1.0 & 0.5 & 0.8 \\
\hline Exchange rate (CFA francs per U.S. dollar) & 527.3 & 522.8 & $\ldots$ & 479.2 & $\ldots$ & $\ldots$ & $\ldots$ & $\ldots$ \\
\hline
\end{tabular}

Sources: Cameroonian authorities; and IMF staff estimates and projections. 
Table 3. Cameroon: Monetary Survey, December 2005-December 2008

(Billions of CFA francs, unless otherwise noted)

\begin{tabular}{|c|c|c|c|c|c|c|}
\hline & \multirow{3}{*}{$\frac{2005}{\text { Dec. }}$} & \multirow{3}{*}{$\begin{array}{c}2006 \\
\text { Dec. } \\
\text { Prog. }\end{array}$} & \multirow{2}{*}{\multicolumn{2}{|c|}{$\begin{array}{l}2007 \\
\text { Dec. }\end{array}$}} & \multicolumn{2}{|c|}{2008} \\
\hline & & & & & \multirow{2}{*}{$\begin{array}{l}\text { June } \\
\text { Proj. }\end{array}$} & \multirow{2}{*}{$\frac{\text { Dec. }}{\text { Proj. }}$} \\
\hline & & & Prog. & Est. & & \\
\hline Net foreign assets & 500 & 511 & 1,235 & 1,512 & 1,890 & 2,044 \\
\hline Bank of Central African States (BEAC) & 382 & 361 & 1,048 & 1,297 & 1,670 & 1,824 \\
\hline Commercial banks & 118 & 150 & 188 & 220 & 220 & 220 \\
\hline Net domestic assets & 1,069 & 1,207 & 541 & 520 & 318 & 210 \\
\hline Domestic credit & 1,174 & 1,303 & 725 & 732 & 543 & 426 \\
\hline Net claims on the public sector & 338 & 446 & -166 & -202 & -358 & -555 \\
\hline Net credit to the central government & 238 & 339 & -255 & -305 & -461 & -658 \\
\hline Claims & 461 & 519 & 307 & 80 & 80 & 80 \\
\hline Deposits & -223 & -180 & -561 & -386 & -541 & -738 \\
\hline Credit to autonomous agencies & 22 & 18 & 17 & 17 & 17 & 17 \\
\hline Credit to public enterprises & 78 & 88 & 71 & 86 & 86 & 86 \\
\hline Credit to financial institutions & 4 & 7 & 6 & 25 & 25 & 25 \\
\hline Credit to the private sector & 832 & 851 & 885 & 910 & 877 & 957 \\
\hline Other items (net) & -106 & -97 & -184 & -212 & -226 & -217 \\
\hline Money and quasi money & 1,568 & 1,718 & 1,776 & 2,032 & 2,208 & 2,253 \\
\hline Currency outside banks & 273 & 344 & 262 & 355 & 253 & 369 \\
\hline Deposits & 1,295 & 1,374 & 1,514 & 1,677 & 1,955 & 1,885 \\
\hline \multicolumn{7}{|c|}{ Memorandum items: } \\
\hline \multicolumn{7}{|c|}{ Contribution to the growth of broad money (percentage points) } \\
\hline Net foreign assets & 9.5 & 6.3 & 11.8 & 27.9 & 34.9 & 26.2 \\
\hline Net domestic assets & -5.3 & 2.7 & -8.1 & -9.3 & -11.0 & -15.3 \\
\hline Of which: credit to the central government & -9.0 & -0.9 & -9.6 & -12.5 & -13.2 & -17.4 \\
\hline Private sector credit (annual percentage change) & 10.9 & 7.0 & 3.0 & 5.9 & 4.5 & 5.2 \\
\hline Broad money (annual percentage change) & 4.2 & 9.0 & 3.7 & 18.6 & 23.9 & 10.9 \\
\hline Currency & -15.6 & 4.0 & 1.5 & 37.4 & 2.5 & 3.7 \\
\hline Deposits & 9.6 & 10.3 & 4.1 & 15.3 & 27.3 & 12.4 \\
\hline Velocity (GDP/average M2) & 5.9 & 6.2 & 5.7 & 5.3 & & 5.4 \\
\hline
\end{tabular}

Sources: BEAC; and IMF staff estimates and projections. 
Table 4. Cameroon: Central Government Operations, 2005-09

(Billions of CFA francs)

\begin{tabular}{|c|c|c|c|c|c|c|c|}
\hline & \multirow[t]{2}{*}{2005} & \multirow[t]{2}{*}{2006} & \multicolumn{2}{|c|}{2007} & \multicolumn{2}{|c|}{2008} & \multirow{2}{*}{$\begin{array}{l}2009 \\
\text { Proj. }\end{array}$} \\
\hline & & & Prog. & Est. & Prog. & Proj. & \\
\hline Total revenue and grants & 1,590 & 4,472 & 1,979 & 1,985 & 2,012 & 2,340 & 2,581 \\
\hline Total revenue & 1,543 & 1,808 & 1,830 & 1,867 & 1,924 & 2,252 & 2,473 \\
\hline Oil sector revenue & 439 & 643 & 580 & 631 & 568 & 881 & 993 \\
\hline Nonoil sector revenue ${ }^{1}$ & 1,104 & 1,165 & 1,250 & 1,236 & 1,356 & 1,371 & 1,480 \\
\hline Total grants & 47 & 2,664 & 149 & 118 & 89 & 88 & 108 \\
\hline Total expenditure & 1,278 & 1,366 & 1,597 & 1,542 & 1,811 & 1,908 & 2,071 \\
\hline Current expenditure & 1,055 & 1,097 & 1,188 & 1,151 & 1,273 & 1,376 & 1,445 \\
\hline Wages and salaries & 414 & 419 & 465 & 435 & 510 & 575 & 616 \\
\hline Goods and services & 337 & 381 & 457 & 436 & 501 & 431 & 463 \\
\hline Debt-relief financed & 22 & 19 & 52 & 17 & 51 & 51 & 52 \\
\hline Subsidies and transfers & 175 & 211 & 216 & 230 & 215 & 323 & 319 \\
\hline of which: fuel subsidies ${ }^{1}$ & 17 & 22 & 25 & 16 & 25 & 133 & 119 \\
\hline Pensions & 77 & 72 & 87 & 84 & 95 & 95 & 97 \\
\hline Interest due & 129 & 87 & 50 & 50 & 47 & 47 & 48 \\
\hline External & 111 & 72 & 37 & 37 & 32 & 32 & 32 \\
\hline Domestic & 18 & 15 & 14 & 14 & 15 & 15 & 16 \\
\hline Capital expenditure & 206 & 273 & 410 & 389 & 538 & 532 & 626 \\
\hline Domestic investment & 159 & 177 & 294 & 280 & 359 & 353 & 457 \\
\hline Own-resource financed & 107 & 143 & 188 & 187 & 216 & 210 & 291 \\
\hline Debt-relief financed & 52 & 34 & 107 & 93 & 143 & 143 & 166 \\
\hline Foreign-financed investment & 44 & 64 & 84 & 62 & 135 & 135 & 150 \\
\hline Rehabilitation and participation & 3 & 33 & 32 & 47 & 44 & 44 & 20 \\
\hline Net lending & 0 & 0 & -1 & 14 & -1 & 0 & 0 \\
\hline Unclassified expenditure & 17 & -5 & -1 & -12 & 0 & 0 & 0 \\
\hline \multicolumn{8}{|l|}{ Overall balance, excluding net change in arrears } \\
\hline Excluding grants & 265 & 442 & 233 & 326 & 113 & 344 & 402 \\
\hline Including grants & 312 & 3,106 & 382 & 444 & 202 & 432 & 510 \\
\hline Net change in arrears & -73 & -170 & -71 & -78 & -35 & -35 & -22 \\
\hline External & -11 & 3 & 0 & 0 & 0 & 0 & 0 \\
\hline Domestic & -62 & -173 & -71 & -78 & -35 & -35 & -22 \\
\hline \multicolumn{8}{|l|}{ Overall balance, cash basis } \\
\hline Excluding grants & 192 & 272 & 161 & 248 & 78 & 309 & 380 \\
\hline Including grants & 239 & 2,936 & 310 & 366 & 167 & 397 & 488 \\
\hline Financing & -239 & $-2,938$ & -310 & -366 & -167 & -397 & -488 \\
\hline External financing, net & -35 & $-2,476$ & -27 & -47 & 74 & 74 & 68 \\
\hline Amortization & -273 & $-2,635$ & -87 & -87 & -71 & -71 & -71 \\
\hline Drawings & 38 & 38 & 61 & 40 & 146 & 146 & 139 \\
\hline Project financing & 38 & 38 & 61 & 40 & 125 & 125 & 139 \\
\hline Program financing (loans) & 0 & 0 & 0 & 0 & 21 & 21 & 0 \\
\hline Debt rescheduling & 0 & 14 & 0 & 0 & 0 & 0 & 0 \\
\hline Exceptional financing & 200 & 107 & 0 & 0 & 0 & 0 & 0 \\
\hline Domestic financing, net & -204 & -462 & -284 & -318 & -241 & -472 & -556 \\
\hline Banking system & -139 & -305 & -164 & -217 & -142 & -353 & -457 \\
\hline Banking system, excluding HIPC and C2D & -151 & -238 & -78 & -182 & -134 & -345 & -483 \\
\hline Net HIPC flows & 12 & -2 & -23 & -9 & 2 & 2 & 26 \\
\hline Net C2D flows & $\ldots$ & -65 & -63 & -26 & -10 & -10 & 0 \\
\hline Amortization & -69 & -159 & -110 & -106 & -79 & -79 & -59 \\
\hline Non-bank financing & 5 & 2 & 0 & 4 & 0 & 0 & 0 \\
\hline Reserves & 0 & 0 & -10 & 0 & -20 & -40 & -40 \\
\hline \multicolumn{8}{|l|}{ Memorandum items: } \\
\hline HIPC-financed spending & 75 & 52 & 73 & 56 & 78 & 78 & 95 \\
\hline C2D-financed spending & 0 & 0 & 62 & 53 & 80 & 80 & 90 \\
\hline MDRI-financed spending & 0 & 0 & 23 & 2 & 36 & 36 & 33 \\
\hline Nonoil primary balance (program definition) ${ }^{2}$ & 76 & 36 & -46 & -37 & -71 & -153 & -190 \\
\hline Nonoil current balance, excl. grants and arrears & 32 & 73 & 84 & 93 & 107 & 20 & 62 \\
\hline
\end{tabular}

Sources: Cameroonian authorities; and IMF staff estimates and projections.

${ }^{1}$ Beginning in 2008, support provided to SONARA through lower taxes is replaced by an explicit subsidy, with an equivalent increase in nonoil revenues.

${ }^{2}$ Excludes restructuring, HIPC- and C2D-financed expenditures, in addition to grants, interest, and foreign-financed expenditure. 
18

Table 5. Cameroon: Selected Fiscal Indicators, 2005-09

(Percent of GDP, unless otherwise indicated)

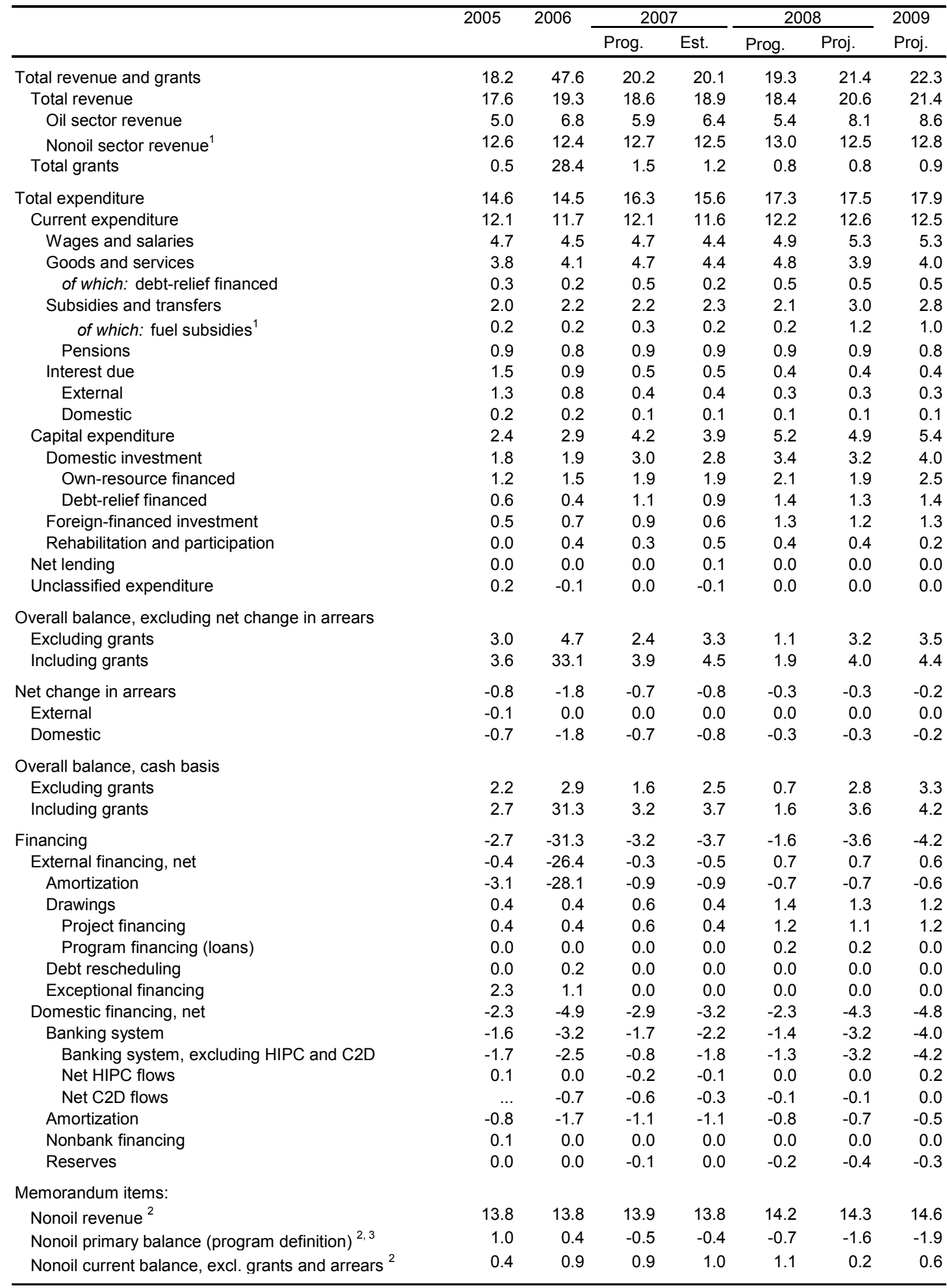

Sources: Cameroonian authorities; and IMF staff estimates and projections.

${ }^{1}$ Beginning in 2008, support provided to SONARA through lower taxes is replaced by an explicit subsidy, with an equivalent increase in nonoil revenues.

${ }^{2}$ Percent of nonoil GDP.

${ }^{3}$ Excludes restructuring, HIPC- and C2D-financed expenditures, in addition to grants, interest, and foreign-financed capital expenditures. 
Table 6. Cameroon: Indicators of Capacity to Repay the Fund, 2007-17

\begin{tabular}{|c|c|c|c|c|c|c|c|c|c|c|c|}
\hline & 2007 & 2008 & 2009 & 2010 & 2011 & 2012 & 2013 & 2014 & 2015 & 2016 & 2017 \\
\hline & \multicolumn{11}{|c|}{ Projections } \\
\hline \multicolumn{12}{|l|}{$\begin{array}{l}\text { Fund obligations based on existing credit } \\
\text { (In millions of SDRs) }\end{array}$} \\
\hline Principal & - & - & - & - & 0.8 & 1.6 & 2.4 & 2.7 & 2.7 & 1.9 & 1.1 \\
\hline Charges and interest & 0.9 & 0.7 & 0.7 & 0.7 & 0.7 & 0.7 & 0.7 & 0.7 & 0.6 & 0.6 & 0.6 \\
\hline \multicolumn{12}{|l|}{$\begin{array}{l}\text { Fund obligations based on existing and prospective credit } \\
\text { (In millions of SDRs) }\end{array}$} \\
\hline Principal & - & - & - & - & 0.8 & 1.6 & 2.4 & 3.7 & 3.7 & 2.9 & 2.1 \\
\hline Charges and interest & 0.9 & 0.7 & 0.7 & 0.7 & 0.7 & 0.7 & 0.7 & 0.7 & 0.7 & 0.6 & 0.6 \\
\hline \multicolumn{12}{|l|}{ Total obligations based on existing and prospective credit } \\
\hline In millions of SDRs & 0.9 & 0.7 & 0.7 & 0.7 & 1.5 & 2.3 & 3.1 & 4.4 & 4.4 & 3.6 & 2.8 \\
\hline In billions of CFA francs & 0.7 & 0.5 & 0.5 & 0.5 & 1.0 & 1.5 & 2.0 & 2.9 & 2.9 & 2.3 & 1.8 \\
\hline In percent of government revenue & 0.0 & 0.0 & 0.0 & 0.0 & 0.0 & 0.1 & 0.1 & 0.1 & 0.1 & 0.1 & 0.0 \\
\hline In percent of exports of goods and services & 0.0 & 0.0 & 0.0 & 0.0 & 0.0 & 0.0 & 0.1 & 0.1 & 0.1 & 0.1 & 0.0 \\
\hline In percent of debt service $2 /$ & 0.6 & 0.5 & 0.5 & 0.6 & 1.3 & 2.4 & 3.4 & 5.0 & 5.6 & 4.8 & 4.1 \\
\hline In percent of GDP & 0.0 & 0.0 & 0.0 & 0.0 & 0.0 & 0.0 & 0.0 & 0.0 & 0.0 & 0.0 & 0.0 \\
\hline In percent of quota & 0.5 & 0.4 & 0.4 & 0.4 & 0.8 & 1.2 & 1.7 & 2.4 & 2.4 & 1.9 & 1.5 \\
\hline Outstanding Fund credit ${ }^{2}$ & & & & . & & & & & & & \\
\hline In millions of SDRs & 10.6 & 18.6 & 18.6 & 18.6 & 17.8 & 16.2 & 13.8 & 10.1 & 6.4 & 3.5 & 1.3 \\
\hline In billions of CFA francs & 7.8 & 12.5 & 12.5 & 12.4 & 11.8 & 10.7 & 9.1 & 6.6 & 4.2 & 2.3 & 0.9 \\
\hline In percent of government revenue & 0.4 & 0.6 & 0.5 & 0.5 & 0.4 & 0.4 & 0.3 & 0.2 & 0.1 & 0.1 & 0.0 \\
\hline In percent of exports of goods and services & 0.3 & 0.4 & 0.4 & 0.4 & 0.4 & 0.3 & 0.3 & 0.2 & 0.1 & 0.1 & 0.0 \\
\hline In percent of debt service ${ }^{2}$ & 7.2 & 12.4 & 12.7 & 14.5 & 15.5 & 16.8 & 15.2 & 11.5 & 8.1 & 4.7 & 2.0 \\
\hline In percent of GDP & 0.1 & 0.1 & 0.1 & 0.1 & 0.1 & 0.1 & 0.1 & 0.0 & 0.0 & 0.0 & 0.0 \\
\hline In percent of quota & 5.7 & 10.0 & 10.0 & 10.0 & 9.6 & 8.7 & 7.4 & 5.4 & 3.4 & 1.9 & 0.7 \\
\hline Net use of Fund credit (millions of SDRs) & 5.3 & 8.0 & - & - & -0.8 & -1.6 & -2.4 & -3.7 & -3.7 & -2.9 & -2.1 \\
\hline Disbursements & 5.3 & 8.0 & - & - & - & - & - & - & - & - & - \\
\hline Repayments and Repurchases & - & - & - & - & 0.8 & 1.6 & 2.4 & 3.7 & 3.7 & 2.9 & 2.1 \\
\hline \multicolumn{12}{|l|}{ Memorandum items: } \\
\hline Nominal GDP (in billions of CFA francs) & 9,894 & 10,929 & 11,560 & 12,242 & 13,102 & 14,028 & 15,061 & 16,175 & 17,369 & 18,653 & 20,034 \\
\hline Exports of goods and services (in billions of CFA francs) & 2,648 & 3,119 & 3,181 & 3,197 & 3,238 & 3,302 & 3,368 & 3,472 & 3,562 & 3,674 & 3,804 \\
\hline Government revenue (in billions of CFA francs) & 1,867 & 2,252 & 2,473 & 2,583 & 2,719 & 2,846 & 3,021 & 3,187 & 3,344 & 3,524 & 3,730 \\
\hline Debt service (in billions of CFA francs) ${ }^{2}$ & 108 & 101 & 98 & 86 & 77 & 64 & 60 & 58 & 52 & 49 & 44 \\
\hline
\end{tabular}

Sources: IMF staff estimates and projections.

${ }^{1}$ Including remaining disbursements under the current PRGF arrangement.

${ }^{2}$ Total debt service includes IMF repurchases and repayments. 
Table 7. Cameroon: Fund Disbursements and Timing of Reviews Under the PRGF Arrangement, 2005-08

\begin{tabular}{|c|c|c|}
\hline Date of Availability ${ }^{1}$ & Conditions & $\begin{array}{c}\text { Amount } \\
\text { (Millions of SDRs) }\end{array}$ \\
\hline November 1, 2005 & Board approval of the PRGF arrangement & 2.65 \\
\hline May 10, 2006 & $\begin{array}{l}\text { Completion of first review (end-December } \\
2005 \text { quantitative and structural performance } \\
\text { criteria) }\end{array}$ & 2.65 \\
\hline January 12, 2007 & $\begin{array}{l}\text { Completion of second review (end-June } \\
2006 \text { quantitative and structural performance } \\
\text { criteria) }\end{array}$ & 2.65 \\
\hline June 29, 2007 & $\begin{array}{l}\text { Completion of third review (end-December } \\
2006 \text { quantitative and structural performance } \\
\text { criteria) }\end{array}$ & 2.65 \\
\hline January 10, 2008 & $\begin{array}{l}\text { Completion of fourth review (end-June } 2007 \\
\text { quantitative and structural performance } \\
\text { criteria) }\end{array}$ & 2.65 \\
\hline April15, 2008 & $\begin{array}{l}\text { Completion of fifth review (end-December } \\
2007 \text { quantitative and structural performance } \\
\text { criteria); Executive Board meeting planned } \\
\text { for end-June } 2008 \text {. }\end{array}$ & 2.65 \\
\hline September 15, 2008 & $\begin{array}{l}\text { Completion of sixth review (end-June } 2008 \\
\text { quantitative and structural performance } \\
\text { criteria); Executive Board consideration likely } \\
\text { before end-December } 2008 \text {. }\end{array}$ & 2.67 \\
\hline
\end{tabular}

\footnotetext{
${ }^{1}$ For past disbursements, date refers to actual date of disbursement.
} 


\section{APPENDIX I}

Mr. Dominique Strauss-Kahn

Managing Director

International Monetary Fund

70019 th Street, N.W.

Washington, D.C. 20431

United States

June 5, 2008

Dear Mr. Strauss-Kahn:

1. In the second half of 2007 the government continued its efforts to restore the soundness of the macroeconomic framework and implement structural reforms in the context of its economic program supported by the International Monetary Fund (IMF) under the Poverty Reduction and Growth Facility (PRGF). Those efforts made it possible to meet most of the program's quantitative criteria and benchmarks at end-December 2007. A waiver is nonetheless requested for the nonobservance of the performance criterion related to domestic structured debt which was missed by a small margin. Implementation of the structural reforms was generally satisfactory with progress made in strengthening tax administration and in financial sector reforms.

2. Soaring world prices for oil and certain imported staple goods led, however, to an increase in the cost of living and undermined the efforts made in recent years by many countries to improve the living standards of their populations. This situation, which Cameroon was unfortunately unable to avoid, was the cause of the recent transport workers strike, the fallout from which caused not only loss of human life and material damage of all kinds, but also paralyzed economic activity in a number of urban centers in February 2008.

3. As a result of those events, the government had to adopt a series of emergency measures to meet the pressing needs of the population. To ensure the medium-term sustainability of those measures, the government undertakes to reallocate appropriations within the budget, accelerate civil service reform, and strengthen initiatives designed to improve tax administration. However, it will be difficult to accommodate all of the additional costs caused by the emergency measures within the limits of the budget envelope initially programmed for 2008. Hence, the nonoil primary deficit will be lower than the programmed level and the government would like to request a modification of the performance criteria and quantitative benchmarks for end-June.

4. The macroeconomic policies and objectives for the third year of the program and over the medium term remain broadly consistent with the general framework underlying the government's three-year PRGF-supported program. Thus, the attached Memorandum of Economic and Financial Policies (MEFP) supplements the MEFP attached to the letter of intent of November 29, 2007. It evaluates the implementation of the government's economic 
program during the second half of 2007 and presents the economic policies and objectives for 2008 .

5. In implementing their economic and financial program, the authorities have set themselves ambitious medium-term objectives, consistent with the macroeconomic framework of the three-year program. They remain convinced that the need to address the considerable increase in the cost of living makes it imperative to expand Cameroon's production base. In this context, priority will be given to initiatives in favor of agriculture and infrastructure, as well as to improving the business climate. For this purpose, the government intends to step up its efforts to improve the quality of public investment, mobilize nonoil revenue, and combat corruption.

6. The government is convinced that the economic and financial policies described in the attached MEFP will make it possible to meet its economic program targets for 2008 . However, it is prepared to take any further measures that may become appropriate for this purpose. The government will consult with the IMF on the adoption of these measures and in advance of revisions to the policies contained in the MEFP, in accordance with the Fund's policies on such consultations.

7. The government would like to request that the PRGF arrangement be extended until end-January 2009 so as to complete the sixth review. This review will be based on the quantitative and structural performance criteria at end-June 2008.

8. In view of the results obtained so far and the commitments made in the MEFP, the government requests that the sixth disbursement under the PRGF arrangement, an amount equivalent to SDR 2.65 million, be made available upon completion of the fifth review.

9. Finally, the government of Cameroon authorizes the IMF to publish this letter and the attached MEFP.

Sincerely yours,

/s/ Inoni Ephraim

Prime Minister and

Head of Government

Enclosures: - Memorandum on Economic and Financial Policies

- Technical Memorandum of Understanding 


\section{APPENDIX I ATTACHMENT I \\ Memorandum on Economic and Financial Policies}

\section{INTRODUCTION}

1. This memorandum reviews the achievements for the period from July to December 2007 of the three-year program supported by the IMF under the Poverty Reduction and Growth Facility (PRGF), and describes the economic and financial objectives and policies for 2008 and the medium term.

\section{RECENT ECONOMIC DEVELOPMENTS AND RESULTS OF IMPLEMENTATION OF THE PRGF- SUPPORTED PROGRAM}

2. Economic activity edged up in 2007, following a pick-up in the construction, agricultural, and forestry sectors. Nonoil real GDP growth was thus 3.9 percent (compared with 2.9 percent in 2006). The import volume grew on account of the reduced taxation on staple goods (rice, flour, and fish), while the surge in oil prices produced a slight surplus in the current account balance.

3. The strong growth in net foreign assets in 2007 combined with a slower pace of net government deposits in the banking system, led to an acceleration of broad money growth. However, inflation continued to decline, because of the partial pass-though of high oil prices, reduced taxation on some essential goods, and appreciation of the euro.

4. The 2007 budget surplus was higher than projected, mainly because of higher than expected oil revenues. The majority of quantitative targets for end-December 2007 were therefore met, with the exceptions of the performance criterion related to domestic debt and the benchmark on nonoil revenues that were missed by small margins. Execution of the capital budget improved significantly compared with 2006, thanks to efforts to improve the efficiency of expenditure management. However, the high level of treasury float at end fiscal 2007 underscores the need to strengthen the monitoring and control of public expenditure.

5. Progress was achieved with the structural reforms for the period July-December 2007:

- Government finance and fuel pricing policy. Parliament adopted a 2008 Budget Law that was consistent with the objectives of the PRGF-supported program. The single taxpayer identification was also made more secure for large companies. Moreover, the government adopted a new formula for the automatic adjustment of fuel prices (performance criterion for end-December 2007).

- Financial sector. The CAMPOST accounts for the years 2004 to 2006 were produced in the final quarter of 2007. The draft business plan for the financial activities of 
CAMPOST was prepared in November 2007. Transactions involving Treasury zerocoupon bonds became possible on the financial market.

6. Public enterprise reform continues, although at a less sustained pace than initially envisaged. The management contract of SNEC was signed in December 2007. A new financial consultant for the CAMAIR privatization was selected and assessment of the technical bids relating to the privatization of CAMTEL was completed.

7. The government also continued implementation of measures to enhance transparency. The quarterly budget execution reports, the quarterly operating reports of the national oil company (SNH), and the annual financial aggregates of the main public enterprises were published. Debt statistics and analyses were published on the CAA website (www.caa.cm). Judicial decisions and administrative penalties against government employees as part of the anticorruption campaign were also published on the website of the Prime Minister's Office (www.spm.gov.cm).

\section{Economic And Financial Policies in 2008}

\section{A. Macroeconomic Framework}

8. Soaring world prices for oil and certain imported staple goods led to an increase in the cost of living and undermined the efforts made in recent years by many countries to improve the living standards of their populations. This situation, which Cameroon was unfortunately unable to avoid, was the cause of the recent transport workers strike, the fallout from which caused not only loss of human life and material damage of all kinds, but also paralyzed economic activity in a number cities in February 2008.

9. In spite of those events, the favorable trend in economic activity in 2007 is expected to continue into 2008. Thus, real nonoil GDP growth is projected to be 4.6 percent in 2008, mainly as a result of the recovery in the agricultural and services sectors and to the significant increase in public investment. However, the expected acceleration in growth could be affected if building material costs continue to rise. Moreover, inflationary pressures could re-emerge in 2008 in connection with international food prices.

10. The main budget targets of the program for 2008 are part of a medium-term fiscal strategy to increase priority expenditure and improve its quality in order to accelerate economic growth and poverty reduction, while preserving the stability of the macroeconomic framework and fiscal sustainability. In this regard, starting 2009 the authorities intend to increase substantially the resources allocated to production sectors (mainly agriculture) and infrastructure, so as to stimulate in a timely fashion the domestic supply of agricultural products capable of replacing cereal imports of which international prices have considerably risen, and of increasing exports to neighboring countries.

11. In response to the population's concerns about the increasing erosion in purchasing power, the authorities have adopted a series of emergency measures designed to raise household incomes and reduce the cost of living. The series of measures includes, in particular: a raise in civil servants' salaries; suspensions or cuts in taxes and customs duties on some consumer goods; 
and a decrease in retail prices of petroleum products. It also includes the recruitment of civil servants to improve the efficiency of the civil service.

12. To ensure the sustainability of these measures, the government is committed to:

(i) strengthen the mobilization of nonoil revenue; (ii) speed up reform of the civil service, and;

(iii) cut expenditure on goods and services and to redirect the freed-up appropriations to priority spending within the budget. For this purpose, ongoing efforts to reduce the reference prices for government orders will allow budget savings to be made without reducing the quantities allocated to the priority sectors. It is, however, difficult to accommodate all of the additional costs stemming from the emergency measures (estimated at CFAF 158 billion) within the limits of the budget envelope initially allocated for 2008 . Hence, the nonoil primary deficit will be CFAF 82 billion higher than originally planned, which will be financed by higher oil revenues. The authorities will adopt a supplementary budget to take account of those changes.

\section{B. Government Finance and Fiscal Policy Reforms}

13. On the revenue side, the government expects a shortfall of about CFAF 32 billion in nonoil revenues compared with the objectives of the 2008 program because of the tax exemptions granted for certain basic consumer goods. The tax-related measures recently adopted by the government are temporary, and the government is committed to review them during the preparatory work for the 2009 Budget Law. Total revenue (excluding grants) in 2008 should, however, increase by 1.3 percent of GDP compared with 2007, owing to higher oil revenues (1.7 percent of GDP $)^{1}$. To improve VAT administration, the government will continue to ensure that VAT credits are refunded within the time limits provided by law.

14. The mobilization of nonoil revenue remains a major challenge for the country. To meet its revenue targets, the government is committed to accelerating implementation of a number of administrative measures. For example, the number of tax centers for small taxpayers will be reduced with the establishment of experimental pilot sites in Yaoundé and Douala at endSeptember 2008; the extension of ASYCUDA to the main collection sectors (Littoral I, Littoral II, South-West, Center) and to the transit corridors will be completed by end-September 2008; the connection of the information systems of the General Directorate of Taxes and the General Directorate of Customs initially planned for March 2008 (benchmark) will be completed in June 2008; the safeguard of the single taxpayer file will be strengthened through incorporation of a specific module for the single identification number in the tax management system (MESURE) by end-September 2008; and by December 2008, the number of taxpayers covered by the tax centers for medium-sized enterprises in Yaoundé and Douala will grow by some 20 percent compared with the tax rolls at January 1, 2008. In 2009, the government will continue its efforts by adopting measures based on the recommendations of the IMF technical assistance mission of April 2008 and on the action plan of the fiscal reform commission.

\footnotetext{
${ }^{1}$ The principle adopted under the program of using cautious oil price projections is maintained. Thus, the price is estimated at a constant prudence factor of US\$7 a barrel below the projections in the IMF's World Economic Outlook (excluding the US\$3 per barrel discount on Cameroonian crude).
} 
15. Furthermore, in April 2007 the government set up a commission to review domestic and foreign trade taxation and taxes in order to improve the mobilization of nonoil revenues.

The commission, which includes representatives of government, economic operators, and civil society, submitted a summary report on its work and recommendations in December 2007. On the basis of the report, a medium-term tax reform plan will be adopted in the first half of 2008 (benchmark for end-June 2008). The plan is intended to make the current tax system fairer and more efficient and to mobilize nonoil revenues.

16. The government is also committed to improve the collection of property tax, particularly through : (i) a closer monitoring of tax filing by following up systematically on non-compliers and, if needed, by having recourse to presumptive taxation; (ii) a tighter control of the declared valuation of real estate ; and (iii) a stronger recovery. In addition, with the financial assistance of their development partners, the authorities plan to finalize in 2009 the implementation of the fiscal cadastre in Yaoundé and Douala.

17. Furthermore, in order to improve forestry revenue, the government intends to strengthen the role of the Program to Secure Forestry Revenue (PSRF) as the forestry sector's sole point of contact for taxation. Cooperation protocols will be defined between the PSRF and all other entities involved in supervision of the forestry sector. The cooperation protocols will clearly indicate the information required from these entities, as well as the frequency, deadlines, and modalities for transferring the information. Moreover, by end-September 2008, the government intends to establish an online connection between the Ministry of Forests and Wildlife and the Ministry of Finance. This initiative is essential for restoring the capacity to monitor sectoral economic data and control the tax base. The government is also committed to strengthening forestry taxation with the assistance of the World Bank.

18. On the expenditure side, the government will concentrate its efforts on the priority areas of the PRSP and accelerate public investment, particularly in infrastructure and the agriculture, health, and education sectors. The increase in civil servants' salaries and the price freeze on petroleum products will entail a supplemental cost for the budget of around CFAF 126 billion. The government will reduce certain expenditures on goods and services and capital expenditures by approximately CFAF 76 billion.

19. The government is committed to continue its efforts to contain wages and staffing. It will ensure consolidation of the harmonized personnel and payroll records. For this purpose, an integrated management system for the civil service and the payroll will be installed in 24 government agencies, covering 80 percent of civil service employees, by end-June 2008 (benchmark). The system will be extended to the remainder of the civil service by end-2008. The government also intends to replace the current computerized payroll system by a more advanced one, particularly in terms of security and access rights. Moreover, it is committed to conduct an assessment of the current system by December 2008 with the help of the World Bank and, together with the World Bank, to prepare a plan to reform the civil service in the next Country Assistance Strategy. The aim is to design a more efficient civil service policy, allowing rationalization of recruitment and a more productive government.

20. The government also intends to continue strengthening the budget reporting system. In this regard, it is committed, in collaboration with its technical and financial partners, to engage in 
discussions on the preparation of a government financial operations table (TOFE), in the medium-term, on a payment order basis. In order to do so, by end-July 2008 it will conduct a diagnostic study on the measures and the critical path necessary for preparation of the TOFE on a payment order basis for all expenditures, with a detailed costing of the investment required, in particular to equip the various government offices throughout the country. On this basis, the TOFE for the 2007 Budget execution will be produced by end-September 2008. In the meantime, the government will step up its efforts to improve the monitoring and management of treasury float (benchmark at end-June 2008). The government is also committed to finalize, by endAugust 2008, a plan to intensify its measures to improve public expenditure management as part of the platform bringing together its technical and financial partners.

21. The government is committed to continue using any windfall in oil revenue exclusively to financing nonrecurrent expenditure, in particular to: (i) accelerate payments on domestic debt and arrears; (ii) buy back debt held by external commercial creditors who did not take part in the commercial debt repurchase initiative within the London Club; and (iii) finance investment in the sectors specified in the PRSP, including the counterpart funds for jointly-financed projects such as infrastructure development (in particular roads and energy) and investment in major sectoral programs (education, health, and rural and urban development).

\section{Fuel Pricing Policy}

22. The government maintains its commitment to gradually reducing subsidies for the consumption of petroleum products and at the same time applying a policy of periodically adjusting their retail prices in line with developments in market conditions. Accordingly, at endDecember 2007 the government adopted a formula for the revision of SONARA ex-refinery prices and a simplified price structure. The new price structure, which came into force in January 2008, is more transparent, eliminating the cross-subsidization and tax distortions present in the previous structure. In particular, an explicit subsidy replaces the support that the government is providing SONARA through lower taxation with an identical increase in revenue.

23. In view of the steep increase in world oil prices, raising strongly voiced concerns from consumers and social partners, the government decided to temporarily freeze the retail prices of petroleum products. It considers that this measure will require a CFAF 61 billion increase in budget transfers to SONARA, bringing total transfers for 2008 to CFAF 133 billion (including CFAF 47 billion from implementation of the new pricing formula). The government is committed to take the appropriate measures to maintain budget transfers to SONARA within the programmed limits. Should world oil prices turn out to be much higher than expected, the government will review this policy and seek appropriate solutions, including a possible adjustment of the retail prices of petroleum products.

24. The government is committed to resume implementation of the mechanism for adjusting the retail prices of petroleum products starting in 2009. Fluctuations in world prices for crude oil will therefore be passed on when determining the retail prices of petroleum products by applying the periodic price review formula. The government is also committed to phase out fuel price subsidies and to use the resulting budget savings to improve the social safety net and increase investment in agriculture, health, and basic education. In this regard, a study will be conducted to determine ways and means of implementing this process. 
25. In addition, the government intends to continue implementing measures to strengthen SONARA's financial position and reduce budgetary transfers. For this purpose, the government is in the process of conducting a feasibility study to determine the cost of the investments needed to improve the refining system, their economic viability, and their financing modalities. In particular, the government undertakes not to make any new investment unless its economic viability has been proven and it can be financed within the framework of a sustainable fiscal policy.

\section{External Debt Management and Trade Liberalization}

26. As a result of the debt relief granted to Cameroon by the Paris Club in June 2006, the government has finalized the signing of agreements with all bilateral creditors. It will continue to negotiate in good faith with its private creditors to clear its arrears, without overlooking the principle of comparable treatment.

27. The government will conduct a prudent debt policy and ensure that its debt is managed in a sustainable manner. It intends to finalize preparation of a new comprehensive strategy for debt and public debt management, in accordance with the directive of the Council of Ministers of the Central African Economic and Monetary Community (CEMAC), approved in March 2007. For this purpose, it has requested technical assistance from the International Monetary Fund. This strategy, which will be adopted by end-September 2008 at the latest by the Public Debt Coordination and Monitoring Unit, will be developed and updated annually and annexed to the Budget Law. It will be consistent with the macroeconomic framework, the medium-term fiscal objectives, and will include in particular, the following elements: an annual debt ceiling; the contracting of loans on concessional terms; detailed study of the projects for which borrowing is necessary; a debt sustainability analysis (at least once a year) before the signing of any loan for an amount above 0.5 percent of GDP.

28. In the context of the CEMAC institutional reform program and consolidation of subregional integration, Cameroon undertakes to propose to the other member countries: (i) an assessment of and reduction in the obstacles to development of intraregional trade, including the freedom of movement of goods within the CEMAC zone; (ii) continued efforts to contain and reduce exemptions; and (iii) inclusion of this issue on the agenda of the next meeting of CEMAC. Furthermore, after raising these matters with the Community bodies, Cameroon will continue to support CEMAC reforms through a gradual reduction in the CEMAC Common External Tariff from 30 to 20 percent. Moreover, after eliminating the minimum values for fish and salt, Cameroon undertakes to continue to eliminate administrative minimum values for all imported products until June 30, 2008. To facilitate foreign trade transactions, the government also undertakes to finalize the interface between those parties involved in port transactions on June 30, 2008 with a view to the operational implementation of the electronic one-stop shop (benchmark for June 30, 2008). Finally, on December 17, 2007 Cameroon initialed an interim agreement with the European Union with a view to concluding an economic partnership agreement. 


\section{E. Financial Sector}

29. The government is committed to continue implementing its action plan to strengthen financial intermediation. The plan was prepared in December 2007 on the basis of the recommendations of the Joint IMF-World Bank mission in the context of the Financial Sector Assessment Program (FSAP) and it aims in particular to: (i) increase the banking sector's resilience to withstand external shocks; (ii) establish a regional government securities market; (iii) strengthen oversight of microfinance; (iv) facilitate access to banking services; (v) improve information on the cost of credit and payment defaults; (vi) strengthen the legal framework; and (vii) diversify financial instruments.

30. In this regard, the list of accredited microfinance institutions (MFIs) was published in February 2008 to better protect depositors. The government is also committed, at the national level, to support initiatives to facilitate access to credit by reducing constraints linked to the business environment, in particular by: (i) significantly improving financial reporting; (ii) simplifying procedures for calling in collateral; and (iii) setting up a commercial court. In addition, the government will ensure that a solution is found for the difficulties of the two intervened banks.

31. The government will also work with the Bank of Central African States (BEAC) to update in the central credit register the list of clients in default of liquidated or restructured banks, by end-December 2008. Moreover, the government undertakes to propose to COBAC that it adopts a regulation requiring credit institutions in the subregion to publish their lending terms on a regular basis in an effort to make credit operations transparent. An appropriate legal framework for factoring, leasing, and venture capital will be adopted and the legislation on the opening and closing of bank branches will be modified by end-December 2008. At the regional level, the government also undertakes to support the BEAC in finalizing implementation of the central credit register (computerization, payment problems register, and financial analysis center).

32. Moreover, the government will continue its efforts to develop the securities market. It undertakes to limit recourse to all new statutory advances and to issue publicly-traded government securities. Transactions involving government securities will take place under the supervision of the Financial Markets Commission (CMF).

33. The government also plans to hold detailed discussions to determine the best way for CAMPOST to offer financial services throughout the country on the basis of the business plan prepared for the company's financial activities. To safeguard the replenishment of the assets of the company, the authorities undertake to continue ensuring financial supervision of CAMPOST by the unit within the Ministry of Finance in charge of the oversight of nonbank financial institutions, which will produce a quarterly supervision report. The next report, on the operations of the last quarter of 2007, will be available at end-June 2008. Furthermore, transfers to CAMPOST will be limited to the minimum amount needed to meet the required annual working capital, estimated at CFAF 22.5 billion. CAMPOST will also be notified of the requirement to present the accounts for its financial activities separately from those of its postal activities. 


\section{F. Business Environment}

34. Apart from fiscal and tax policy measures, which address immediate concerns, the government remains convinced that addressing the high cost of living requires the expansion of Cameroon's production base. To achieve this, emphasis will be placed on accelerating growth, in particular by improving the business climate. For this purpose, by end-December 2008, and in partnership with the private sector and in collaboration with its development partners, the government will prepare a plan to develop the private sector. The government will also introduce, by end-December 2008, a one-stop shop for business creation to reduce the time and expense of setting-up a business. Moreover, the government will consider the possibility of developing certain agricultural sub-sectors with the assistance of the World Bank.

35. The government is determined to strengthen good governance and to fight corruption. Accordingly, it will continue to publish on the Internet a summary of the reports of the local committees monitoring the physical and financial execution of the investment projects in the central government budget, as well as the judicial decisions and administrative penalties against civil servants. Furthermore, the government will continue its work to launch the operations of the Commission planned to implement the asset disclosure process for senior government officials. Moreover, the government will prepare, by end-December 2008, an anti-corruption strategy based on the joint CHOC program (Change Habits-Out with Corruption) of the government and donors, adopted in February 2007.

36. The government will continue implementation of its public enterprise privatization and restructuring programs to improve the performance of these enterprises and lessen the burden they represent both for the budget and the Cameroonian economy in general. In the case of CAMTEL, the government has prepared the financial information for 2006 and taken account of the suggestions made by investors to improve the structure of the transaction originally proposed. The aim is to complete the selection of a provisional successful bidder by end-September 2008 . In the case of the airline industry, the government remains determined to eliminate government subsidies for airline companies, including CAMAIR, and to improve the quality of service in air transportation. For this purpose, the government is committed to phase out subsidies for CAMAIR by June 2008, and to complete the splitting-up and liquidation of the company by March 2009. Moreover, the tender to select a private strategic partner will be launched by endAugust 2008.

\section{Monitoring Program Implementation}

37. Program monitoring from January to end-June 2008 will be based on the performance criteria, quarterly quantitative, and structural benchmarks shown in Tables 1-2. However, in view of the events of February 2008, the government would like to request a modification of the performance criteria and quantitative benchmarks for end-June and the PRGF arrangement to be extended until January 2009 so that the sixth review can be completed. The government will report the data necessary for program monitoring to the IMF, in accordance with the Technical Memorandum of Understanding. 


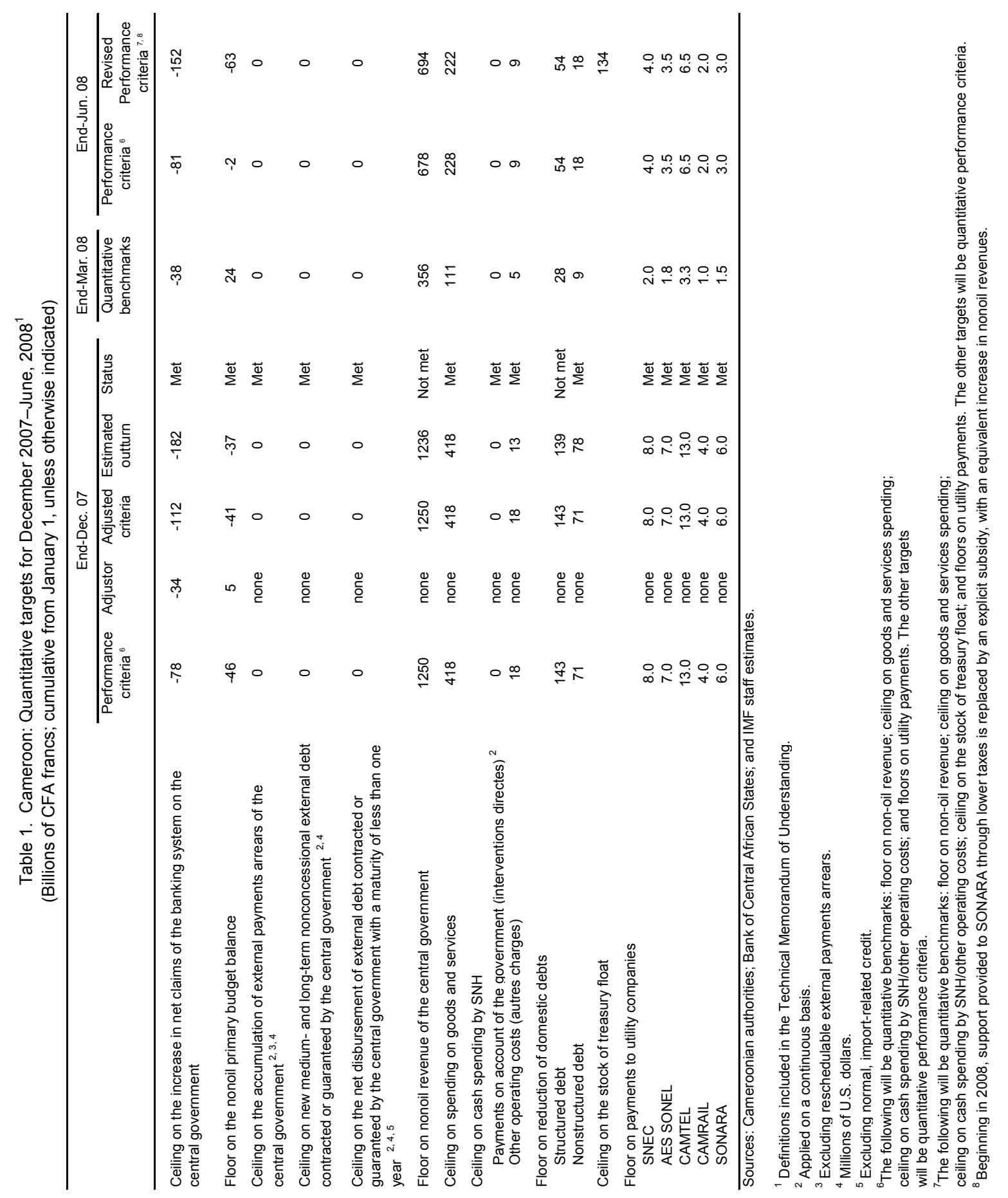




\begin{tabular}{|c|c|c|}
\hline & Deadline & Status \\
\hline \multicolumn{3}{|l|}{ Public Finance and Civil Service } \\
\hline $\begin{array}{l}\text { Completion of the work related to streamlining taxpayer } \\
\text { identification, upgrading the single identification software, and } \\
\text { safeguarding the single taxpayer file. }\end{array}$ & December 31, 2007 & Completed \\
\hline $\begin{array}{l}\text { Adoption by the government of a formula for the revision of } \\
\text { SONARA exit refinery prices and a simplified structure of } \\
\text { petroleum product prices to facilitate automatic adjustment } \\
\text { (performance criterion). }\end{array}$ & December 31, 2007 & Completed \\
\hline $\begin{array}{l}\text { Submission to Parliament the } 2008 \text { Budget Law in accordance } \\
\text { with the program. }\end{array}$ & December 31, 2007 & Completed \\
\hline $\begin{array}{l}\text { Completion of the work to connect the information system of } \\
\text { the General Directorate of Taxes (MESURE) to that of the } \\
\text { General Directorate of Customs (ASYCUDA). }\end{array}$ & March 31, 2008 & Delayed \\
\hline $\begin{array}{l}\text { Installation of the Automated Integrated Management System } \\
\text { (SIGIPES) covering civil servants and the payroll in } 24 \\
\text { ministries. }\end{array}$ & June 30,2008 & \\
\hline $\begin{array}{l}\text { Adoption of a medium-term tax reform plan building upon the } \\
\text { recommendations of the Review Commission of Domestic and } \\
\text { Foreign Trade Taxation. }\end{array}$ & June 30, 2008 & \\
\hline $\begin{array}{l}\text { Adjustment of retail prices of petroleum product and payment } \\
\text { of budgetary transfers to SONARA as agreed with Fund staff. }\end{array}$ & Ongoing & \\
\hline \multicolumn{3}{|l|}{ Financial Sector, Trade, and the Business Climate } \\
\hline $\begin{array}{l}\text { Transfer of secondary-market transactions on zero-coupon } \\
\text { treasury bonds to the financial market. }\end{array}$ & December 31, 2007 & Completed \\
\hline $\begin{array}{l}\text { Presentation to Parliament of the Law on Electronic } \\
\text { Communications and Electronic Payments of Banks. }\end{array}$ & June 30, 2008 & \\
\hline $\begin{array}{l}\text { Complete and implement the electronic one-stop shop to } \\
\text { facilitate foreign trade. }\end{array}$ & June 30, 2008 & \\
\hline $\begin{array}{l}\text { Financial supervision of CAMPOST by the unit of the Ministry } \\
\text { of Finance in charge of the monitoring of nonbank financial } \\
\text { institutions, and production by this unit of the quarterly } \\
\text { supervisory report covering the operations of the final quarter } \\
\text { of } 2007 \text { (performance criterion). }\end{array}$ & June 30, 2008 & \\
\hline
\end{tabular}


Table 3. Cameroon: Quantitative Indicative targets for July-December, $2008^{1}$ (Billions of CFA francs; cumulative from January 1, unless otherwise indicated)

End-Sep. 08 End-Dec. 08

Ceiling on the increase in net claims of the banking system on the $-203$ $-345$ central government

Floor on the nonoil primary budget balance

Ceiling on the accumulation of external payments arrears of the central government ${ }^{2,3,4}$

Ceiling on new medium- and long-term nonconcessional external debt

0 contracted or guaranteed by the central government 2,4

Ceiling on the net disbursement of external debt contracted or 0 guaranteed by the central government with a maturity of less than one year $2,4,5$

Floor on nonoil revenue of the central government

Ceiling on spending on goods and services

Ceiling on cash spending by $\mathrm{SNH}$

Payments on account of the government (interventions directes) ${ }^{2}$ Other operating costs (autres charges)

$\begin{array}{cc}0 & 0 \\ 14 & 18 \\ & \\ 81 & 108 \\ 26 & 35 \\ 134 & 134 \\ & \\ 6.0 & 8.0 \\ 5.3 & 7.0 \\ 9.8 & 13.0 \\ 3.0 & 4.0 \\ 4.5 & 6.0\end{array}$

Floor on reduction of domestic debts

Structured debt 108

Nonstructured debt 134

Ceiling on the stock of treasury float 8.0

SNEC

AES SONEL

7.0

CAMTEL 3.0

CAMRAIL 6.0

Sources: Cameroonian authorities; Bank of Central African States; and IMF staff estimates.

${ }^{1}$ Definitions included in the Technical Memorandum of Understanding.

${ }^{2}$ Applied on a continuous basis.

${ }^{3}$ Excluding reschedulable external payments arrears.

${ }^{4}$ Millions of U.S. dollars.

${ }^{5}$ Excluding normal, import-related credit. 
Table 4. Cameroon: Central Government Operations, 2008 (Billions of CFA francs, unless otherwise indicated)

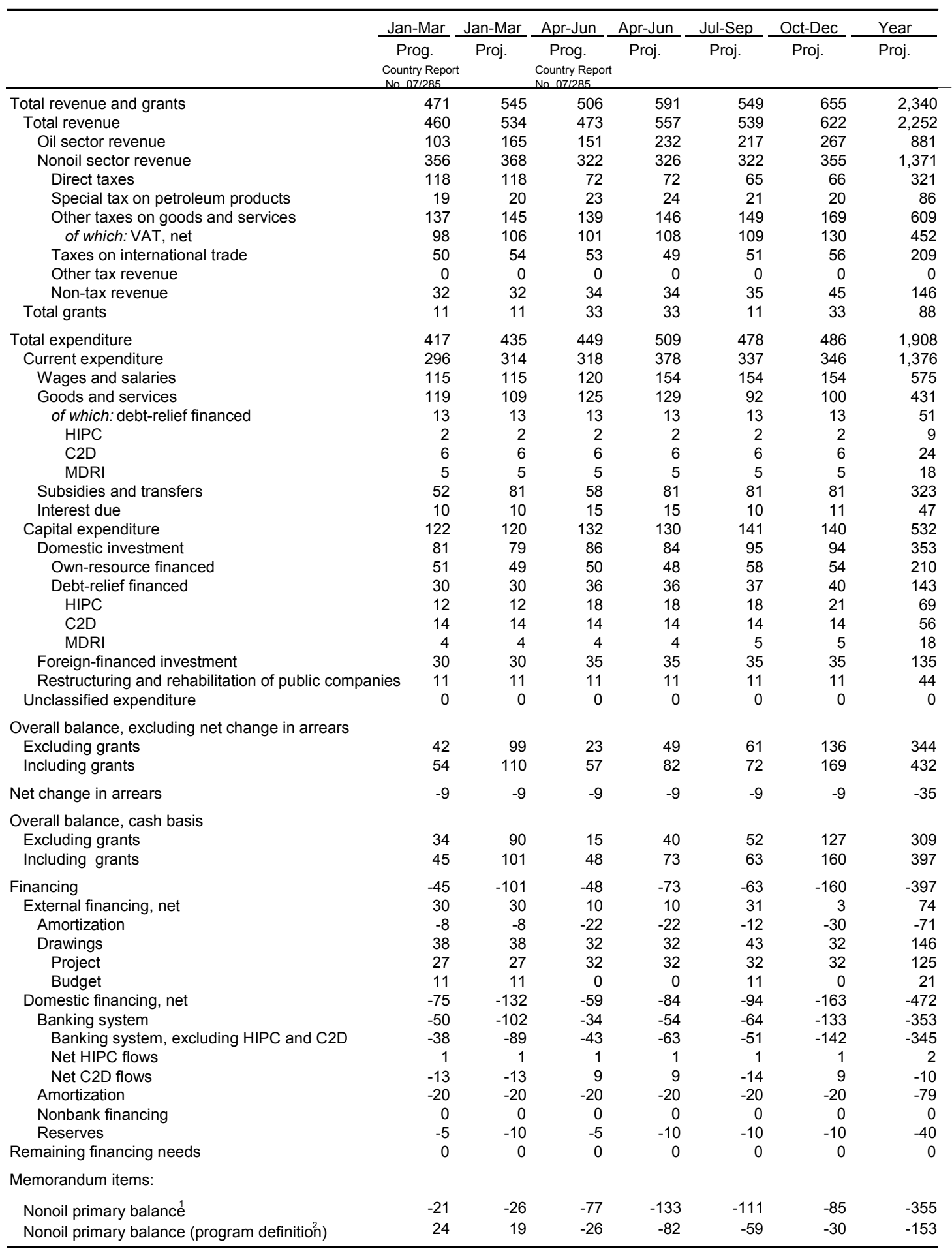

Sources: Cameroonian authorities; and IMF staff estimates and projections.

${ }^{1}$ Excludes grants, interest, and foreign-financed capital expenditures.

${ }^{2}$ Excludes restructuring, HIPC- and C2D-financed expenditures, in addition to grants, interest, and foreign-financed capital expenditures. 


\section{APPENDIX I \\ ATTACHMENT II \\ Technical Memorandum of Understanding \\ on the Definitions of the Performance Criteria and Benchmarks of the PRGF- Supported Program for January-June 2008 and the Modalities of Their Adjustment}

\section{A. Introduction}

1. This memorandum sets out the understandings between the Cameroonian authorities and the International Monetary Fund (IMF) regarding the definitions of the performance criteria and benchmarks of the program and the contingency mechanisms related thereto. It also specifies the program's exchange rates and the data to be reported to the IMF by the authorities.

\section{B. Definitions}

\section{Government}

2. Government is defined as central government unless otherwise noted.

\section{External debt}

3. External debt shall have the meaning set out in point 9 of the Guidelines on Performance Criteria with Respect to External Debt in Fund Arrangements (IMF Executive Board Decision No. 12274-00/85, dated August 24, 2000). External debt is defined on the basis of residency. However, for assessment of the program, debt issued by Cameroonian entities in CFA francs and held by residents of the member countries of the CEMAC zone shall not be considered to be external debt.

\section{Accumulation of external arrears}

4. External arrears are considered to be the external nonreschedulable arrears of the government, including public enterprises whose debt is guaranteed by the government. External nonreschedulable arrears includes the servicing of debt which is due and not paid to all multilateral creditors and to bilateral official and commercial creditors with whom a debt rescheduling or restructuring agreement has been concluded. The nonpayment of debt service to bilateral official and commercial creditors with whom a rescheduling or restructuring agreement has not yet been signed is not considered to be an arrear for the purposes of the program, provided that Cameroon is engaged in best efforts to negotiate a rescheduling or restructuring agreement with bilateral official and commercial creditors. 


\section{Concessionality of external debt}

5. Medium- and long-term debt is considered to be debt with an initial maturity of one year or more. Debt with a maturity of one year or more is considered to be concessional if it includes a grant element equivalent to 35 percent or more, calculated on the basis of the commercial interest reference rate (CIRR) published by the OECD and following the methodology set out in the IMF staff paper entitled "Limits on External Debt or Borrowing in Fund Arrangement - Proposed Change in Implementation of the Revised Guidelines," approved by the IMF Executive Board on April 15, 1996. Thus, for debt maturing in 15 years or more, the OECD 10-year CIRR is used as the discount rate to assess concessionality. The following margins are added to the two CIRRs for the various repayment periods: 1 percent between 15 and 19 years; 1.15 percent between 20 and 29 years; and 1.25 percent when the repayment period is spread over 30 years or more. Debt rescheduling and restructuring as well as the use of IMF resources are not part of the performance criteria for the issuance or guarantee of nonconcessional debt.

\section{Debt relief}

6. For the purpose of the program, the only form of debt relief that will be subject to the contingency mechanism described below is the debt relief that leads to an effective reduction in programmed debt service. This includes, in particular, any relief in the form of rescheduling, forgiveness, restructuring, or a grant under the Heavily Indebted Poor Countries (HIPC) Debt Initiative, the Multilateral Debt Relief Initiative (MDRI), and bilateral initiatives (e.g., C2D—Debt Reduction and Development Contract). Programmed debt relief on debt that has been in drawn-out rescheduling/restructuring negotiations with non-Paris Club creditors, including commercial creditors, is excluded from the contingency mechanism as it does not lead to an effective reduction in programmed debt service.

\section{Domestic debt}

\section{Structured debt}

7. Structured debt is defined as debt that has been subject to a formal agreement (convention) or securitization (titrisation). For the purposes of the PRGF program, structured debt is limited to the stock of structured debt at end-December 2004 that was included in the audit completed in October 2005 and that is specified in the multiyear settlement plan for public domestic debt as recorded by the National Amortization Fund (CAA). The stock of this debt (excluding the BEAC's advances) at end-December 2004 amounted to CFAF 956 billion. 


\section{Nonstructured debt}

8. Nonstructured debt is defined as debt not subject to a formal agreement (convention) or securitization (titrisation). For the purposes of the PRGF program, nonstructured debt is limited to the stock of nonstructured debt at end-December 2004 that was included in the audit completed in October 2005 and that is specified in the multiyear settlement plan for public domestic debt as recorded by the National Amortization Fund. The stock of this debt at end-December 2004 amounted to CFAF 496 billion.

\section{Domestic debt repayments}

9. For assessing the observance of the quantitative performance criteria on the reduction of domestic debt, only those repayments of domestic debt are counted that are made to repay the structured and nonstructured domestic debt defined above. These repayments are recorded "below the line" in the Fund's "Central Government Operations" table. In the case of structured debt, they are (i) the payments on account of the securitized debt to the BEAC and commercial banks, which are entered in the line "Domestic financing, net - Banking System - Banking system excl. HIPC and C2D"; and (ii) other repayments of principal, which are recorded in the line "Domestic financing, net - Amortization". In the case of nonstructured debt, they are the repayments of principal, which are recorded in the line "Net change in arrears - Domestic".

\section{Treasury float}

10. Treasury float are defined as the difference between payment orders issued by the central services, excluding debt and C2D spending, and payments relating to those orders at the end of the program review period. Payments by external services are excluded.

Information to help determine the amount of the treasury float can be found in the table Annex 3 of the TABORD.

\section{Government financial operations table (TOFE)}

11. The Treasury balance (Balance des comptes $d u$ Trésor) shows government revenue and expenditure posted in Class 6 accounts (current expenditure), Class 7 accounts (current revenue), and Class 2 accounts (investment operations). Debt-related operations are recorded in Class 1 accounts (debt operations) and partly in Class 5 (financial operations). The financial operations data must be consistent with the data in the treasury account at the BEAC. Data on provisional revenue and expenditure operations and deposits of the correspondents of the treasury are recorded in Class 4 accounts of the government's chart of accounts (plan comptable). Government operations that are not carried out through the Treasury need to be added to the data on operations that are carried out through the Treasury. Revenue and expenditure operations are recorded on a cash basis. 


\section{Nonoil revenue}

12. Nonoil revenue comprises all government (tax and non-tax) revenue, excluding revenue from oil companies (i.e. companies engaged in crude oil extraction in Cameroon) and oil royalties (redevance pétrolière). VAT is recorded net of VAT refunds. The pipeline fee paid by the Cameroon Oil Transportation Company (CTOCO) is recorded as part of nontax revenue.

\section{Privatization proceeds}

13. For the purposes of the program, privatization proceeds will be understood to mean all funds received by the government from the sale or concessioning of the operation of a public company or organization or publicly owned facility to one or more private company(ies) (including companies that are fully controlled by foreign government(s), private organization(s), or individual(s)). Privatization proceeds also include all funds received from the sale of shares owned by the government in private companies or public enterprises. All privatization proceeds should be recorded on a gross basis; if any costs are incurred in connection with the sale or concessioning, these must be recorded separately as expenditure.

\section{Goods and services}

14. All budgetary expenditures on account of the purchase of goods and services are recorded in the accounts 4000060, 4000090, 4011, 4010060, 48131, 4810 and 40001205 of the Treasury balance account and shown accordingly in the TABORD. HIPC and C2D spending is excluded.

\section{Nonoil primary budget balance}

15. The nonoil primary budget balance (on a cash basis) is calculated as government nonoil revenue, excluding external grants, less all expenditure other than interest payments, foreign-financed investment expenditure, HIPC-financed expenditure, expenditure financed by the Debt Reduction and Development Contract (C2D) and restructuring expenditure.

\section{Net bank credit to the government}

16. Net claims on the government by the banking system comprise the stock of all outstanding claims on the government by the banking system (loans, advances, and any other government debt instruments, such as long-term government securities), less all deposits held by the Treasury with the banking system, excluding the HIPC account, the account for the C2D, and the two accounts held by the CAA in a commercial bank to pay the government's domestic and external debt obligations. 


\section{Payments to utility companies}

17. The floor relating to "payment to utility companies" will be considered observed if payments to the utility companies (water, electricity, fixed-line telephones, railway and refinery companies) are made in quarterly amounts, as indicated in Table 1 of the MEFP. These payments are to exclude fiscal compensation, and they are assessed on the basis of cash disbursements. They are to be registered as current expenditures in the TOFE.

\section{Public enterprise restructuring expenditure}

18. Restructuring expenditures are defined as those expenditures that are made in the context of implementing a privatization strategy (CAMAIR, CAMTEL, CDC), a publicprivate partnership (SNEC) or a restructuring plan (CAMPOST, SONARA). The classification of an expenditure as "restructuring expenditure" should be made after consultation with the IMF.

\section{Spending advances by SNH (interventions directes)}

19. Spending advances (interventions directes) by SNH (Société Nationale des Hydrocarbures) are defined as advance payments by SNH on behalf of the government. They are deducted from the monthly cash revenue transferred by the SNH to the government. There will be no interventions directes in 2006 or thereafter.

\section{Quasi-fiscal spending by SNH (autres charges)}

20. SNH's spending to cover costs that are not shared with the other oil companies as part of the production-sharing agreements are called autres charges (other costs). Some of this is related to SNH's mission, (e.g. decommissioning costs). Other elements of this spending are not related to SNH's oil sector activities and are quasi-fiscal in nature (e.g. the cost of operating the Chad-Cameroon oil pipeline).

\section{Subsidy to fuel consumers}

21. The amount of budgetary transfer to SONARA to cover the fuel subsidy to consumers will amount to the difference between the retail price applied and the price that would be needed to keep SONARA's net result on domestic operations at zero, times the volumes sold by SONARA in the domestic market in the course of a given month. This amount will be calculated jointly by SONARA and CSPH and will be paid during the month $(\mathrm{t}+1)$ subsequent to the reference month $(\mathrm{t})$ for which it has been calculated. If the budgetary transfer does not suffice to cover in full the consumer subsidy/SONARA's shortfall, the government will revise retail prices upward so as to prevent losses on domestic operations at SONARA. 


\section{Modalities of the Contingency Mechanism for the Automatic Adjustment of Targets}

22. The floor on the nonoil primary balance will be adjusted upward by the amount of lower-than-programmed transfers made to SONARA.

23. The ceiling on net bank credit to the government will be adjusted:

- downward up to the amount of higher-than-programmed oil revenue and privatization proceeds that are not used to reduce domestic debt, buy back external debt owed to commercial creditors, or finance one-off investment projects (Country Report No. 07/129, q15 of the MEFP);

- upward/downward by the amount of lower/higher-than-programmed external budget support (grants and loans) and by half of the amount of lower/higher than programmed debt relief (defined in paragraph 6 above); the revision upward will be capped to a cumulative amount of CFAF 15 billion in 2007 and CFAF 7.5 billion in the first half of 2008; for the purpose of the adjuster, budget support is defined as all untargeted grants and loans, excluding C2D, HIPC Initiative and MDRI grants;

- downward by the amount of lower-than-programmed restructuring expenditure;

- downward by the amount of lower-than-programmed payments of domestic debt (as defined above), excluding payments of the structured debt held by the domestic banking system, as entered in the line "Domestic financing, net - Banking System - Banking system excl. HIPC and C2D" in the "Central Government Operations" table).

24. Higher-than-programmed oil revenue and all privatization proceeds will be allocated to repayments of domestic debt (as defined above), buyback external debt owed to commercial creditors, or the financing of one-off investment projects (EBS 06/165, $\mid 15$ of the MEFP). The domestic debt repayments will be made within one month following the end of the quarter in which the surplus occurred.

25. In case the shortfall/excess in oil revenue, external budget support (including debt relief), privatization revenue, and/or adjustments in the ceiling on net bank credit to the government exceed CFAF 20 billion, the government will consult with the staff of the IMF to formulate corrective policies.

\section{Program Exchange Rates}

26. Exchange rates to be applied for the conversion of amounts in SDR or U.S. dollars are US\$1.5042 per SDR and CFAF 445.62 per U.S. dollar for the first quarter of 2008; US\$ 1.5037 per SDR and CFAF 446.30 per U.S. dollar for the second quarter of 2008. Liabilities to the IMF, which are included in the definition of net bank credit to the government, will be valued at the same exchange rates. Any deviation from the exchange rate will lead to a full upward or downward adjustment, as appropriate, of the value of the stock of IMF liabilities to the BEAC, and to a similar adjustment of the ceiling on net bank credit to the government. 


\section{E. Structural Performance Criteria}

27. The performance criterion on supervision of CAMPOST will be considered observed if, by end-June 2008, the Ministry of Finance staff responsible for monitoring nonbank financial institutions prepare a report comprising the following data on the final quarter of 2007: (i) number of accounts opened, (ii) their allocation through the CAMPOST network, (iii) trends in balances, (iv) volume of saving invested and by partner, (v) the various characteristics of the investments, (vi) the interest charged on the investments, and (vii) the existence of minimum cash flow sufficient to accommodate withdrawals by savers at any time.

\section{F. Structural Benchmarks}

28. The benchmark related to completion of the work to connect the General Directorate of Taxes (MESURE) to the General Directorate of Customs (ASYCUDA) will be considered observed if by end-March 2008, the physical infrastructure for information exchanges between the General Directorate of Taxes and the General Directorate of Customs is operational, and either module in these systems can share a specific dataset on the imports or exports of individuals or legal entities as well as on their commercial or industrial activities on the Cameroon market.

29. The benchmark pertaining to the installation of the automated integrated management system covering civil servants and payroll (SIGIPES) in 24 ministries will be considered observed if at end-June 2008: (i) the equipment, the protocol for communication between the various SIGIPES sites, and the SIGIPES application are in place in each of these ministries; (ii) staff have been trained in their use; (iii) the SIGIPES is operating effectively in the said ministries; and (iv) the personnel data of these ministries in the SIGIPES are consistent with the data in the payroll management system. The 24 ministries scheduled for SIGIPES software installation are the following: (1) the Office of the Prime Minister, (2) the Ministry of Higher Education, (3) the Ministry of Public Works, (4) the Ministry of Communication, (5) the Ministry of Forests and Wildlife, (6) the Ministry of Employment and Vocational Training; (7) the Ministry of Labor and Social Security, (8) the Ministry of Justice, (9) the Ministry of Economy, Planning, and Regional Development, (10) the Ministry of Environment and the Protection of Nature, (11) the Ministry of Agriculture and Rural Development, (12) the Ministry of Industry, Mines, and Technological Development, (13) the Ministry of Territorial Administration and Decentralization, (14) the Ministry of Water and Energy, (15) the Ministry of the Civil Service, (16) the Ministry of Basic Education, (17) the Ministry of Public Health, (18) the Ministry of Finance, (19) the Ministry of Secondary Education, (20) the Ministry of External Relations, (21) the Superior Audit Office (Contrôle Supérieure de l'Etat), (22) the Ministry of Urban Development and Housing, (23) the Ministry of Social Affairs, and (24) the Office of the General Delegation to the Sûreté Nationale. 
30. The benchmark pertaining to the adoption of a medium-term tax reform plan will be considered observed if by June 30, 2008 the following actions have been taken: (1) the commission for the review of domestic and trade taxes has officially submitted its final report, including recommendations, to the Ministry of Finance; (2) a plan for the gradual implementation of the recommendations approved by the authorities is prepared and adopted. This plan will seek to achieve: (i) greater fairness in the tax system; (ii) greater efficiency; and (iii) greater mobilization of nonoil revenues.

31. The benchmark on adjustment of the retail prices of petroleum products and payment of budgetary transfers to SONARA as agreed with Fund staff will be considered met if the authorities raise the prices of the three main fuel products, i.e., premium gasoline, oil, and diesel fuel, and make transfer payments as indicated in paragraph 23 of the MEFP and paragraph 21 above (pertaining to subsidies for fuel consumers). Fuel prices are to be raised on the first business day of the month.

32. The benchmark related to the presentation to Parliament of the law on electronic communications and electronic payments of banks will be considered met if by end-June 2008 the government has submitted to Parliament a law defining the regulatory framework for electronic communications and payments in consultation with World Bank staff, including transactions between individuals or legal entities on the one hand and banks on the other.

33. The benchmark related to completion and implementation of the electronic one-stopshop at the port of Douala to facilitate foreign trade will be considered met if, by end-June, 2008, the following operations can be truly carried out by e-users at the port of Douala: (i) access to the GUCE portal; (ii) release of the manifest; (iii) settlement of customs taxes and duties; and (iv) production of statistics on port passage times.

\section{G. Reporting Requirements}

34. The Cameroonian authorities will send data, as per the attached Tables 1 and 2, to the IMF within the time limits set out in that table. The authorities will supply the IMF, on a timely basis, with any additional information that the IMF requests for the purpose of monitoring the implementation of the program. 
Table 1. Cameroon: Data-Reporting Requirements

\begin{tabular}{|c|c|c|c|}
\hline $\begin{array}{l}\text { Category of } \\
\text { Data }\end{array}$ & Table/Report & Frequency & Target Date \\
\hline \multirow[t]{16}{*}{$\begin{array}{l}\text { Financial and } \\
\text { monetary data }\end{array}$} & $\begin{array}{l}\text { Central bank balance sheet, consolidated commercial bank } \\
\text { balance sheet, monetary survey }\end{array}$ & Monthly & $\begin{array}{l}10^{\text {th }} \text { of the month for the } \\
\text { previous month's data for the } \\
\text { preliminary series }\end{array}$ \\
\hline & \multirow{3}{*}{ Net credit by the banking system to the central Government } & \multirow{3}{*}{ Monthly } & $\begin{array}{l}25^{\text {th }} \text { of the month for the } \\
\text { previous month's data for the } \\
\text { final series }\end{array}$ \\
\hline & & & $\begin{array}{l}10^{\text {th }} \text { of the month for the } \\
\text { previous month's data for the } \\
\text { preliminary series }\end{array}$ \\
\hline & & & $\begin{array}{l}25^{\text {th }} \text { of the month for the } \\
\text { previous month's data for the } \\
\text { final series }\end{array}$ \\
\hline & Interest rates & Irregular & $\begin{array}{l}\text { One week after new rates } \\
\text { announced }\end{array}$ \\
\hline & $\begin{array}{l}\text { Transactions through the HIPC Initiative and C2D accounts } \\
\text { opened at the BEAC, including credit and debit }\end{array}$ & Monthly & $\begin{array}{l}10^{\text {th }} \text { of the month for the } \\
\text { previous month's data }\end{array}$ \\
\hline & Status report on all Government deposits at the BEAC & Monthly & $\begin{array}{l}10^{\text {th }} \text { of the month for the } \\
\text { previous month's data }\end{array}$ \\
\hline & $\begin{array}{l}\text { Changes to domestic and custom taxes (budget law and } \\
\text { others) }\end{array}$ & Irregular & $\begin{array}{l}\text { Two weeks after the change } \\
\text { has been made }\end{array}$ \\
\hline & $\begin{array}{l}\text { Government financial operations table (TOFE) on a cash } \\
\text { basis, including revenue, expenditure, financing, and domestic } \\
\text { debt payments (including settlement of domestic arrears) }\end{array}$ & Monthly & $\begin{array}{l}\text { Three weeks after the end of } \\
\text { the month concerned for the } \\
\text { preliminary series. }\end{array}$ \\
\hline & & & $\begin{array}{l}\text { Eight weeks after the end of } \\
\text { the month for the final series }\end{array}$ \\
\hline & $\begin{array}{l}\text { Government financial operations table on a commitment basis } \\
\text { (head office) consistent with the TOFE on a cash basis }\end{array}$ & Monthly & $\begin{array}{l}\text { Three weeks after the end of } \\
\text { the month concerned for the } \\
\text { preliminary series }\end{array}$ \\
\hline & & & $\begin{array}{l}\text { Eight weeks after the end of } \\
\text { the month }\end{array}$ \\
\hline & $\begin{array}{l}\text { Treasury balances of a given month, including table on } \\
\text { expenditure paid but not authorized and the table reconciling }\end{array}$ & Monthly & $\begin{array}{l}\text { Three weeks after the end of } \\
\text { the month }\end{array}$ \\
\hline & the Treasury account at the BEAC and the Treasury balance. & & $\begin{array}{l}\text { Eight weeks after the end of } \\
\text { the month }\end{array}$ \\
\hline & $\begin{array}{l}\text { Report on the implementation of the domestic debt settlement } \\
\text { plan }\end{array}$ & Monthly & $\begin{array}{l}25^{\text {th }} \text { of the month for the } \\
\text { previous month's data }\end{array}$ \\
\hline & $\begin{array}{l}\text { Table on budgetary execution on a functional basis consistent } \\
\text { with the table on Government financial operations on a }\end{array}$ & Monthly & $\begin{array}{l}\text { Eight weeks after the end of } \\
\text { the month for the final series }\end{array}$ \\
\hline
\end{tabular}


Table 1. Cameroon: Data-Reporting Requirements (continued)

\begin{tabular}{|c|c|c|c|}
\hline \multirow[t]{5}{*}{ Data } & Table/Report & Frequency & Target Date \\
\hline & $\begin{array}{l}\text { VAT refunds' balances (both refunds requested and refunds } \\
\text { paid) }\end{array}$ & Monthly & $\begin{array}{l}25^{\text {th }} \text { of the month for the } \\
\text { previous month's data }\end{array}$ \\
\hline & Investment budget execution report & Quarterly & $\begin{array}{l}\text { Two months after the end of } \\
\text { the quarter concerned }\end{array}$ \\
\hline & $\begin{array}{l}\text { HIPC and C2D spending (commitments, authorizations, } \\
\text { payments) }\end{array}$ & Monthly & $\begin{array}{l}25^{\text {th }} \text { of the month for the } \\
\text { previous month's data }\end{array}$ \\
\hline & $\begin{array}{l}\text { SNH operations, including export volumes, exchange rates, } \\
\text { prices, values, operating costs (including a detailed list of } \\
\text { other costs), commitments, transferable balances, spending } \\
\text { advances (interventions directes), and balances transferred } \\
\text { (cash basis), dividends received, and dividends transferred. }\end{array}$ & Monthly & $\begin{array}{l}25^{\text {th }} \text { of the month for the } \\
\text { previous month's data }\end{array}$ \\
\hline \multirow{2}{*}{$\begin{array}{l}\text { Public } \\
\text { companies } \\
\text { data }\end{array}$} & $\begin{array}{l}\text { Payments of bills to public enterprises (SNEC, CAMTEL, } \\
\text { AES SONEL, CAMRAIL, and SONARA) }\end{array}$ & Monthly & $\begin{array}{l}20^{\text {th }} \text { of the month for the } \\
\text { previous month's data }\end{array}$ \\
\hline & $\begin{array}{l}\text { Payments made to or on account of CAMAIR (for bills, } \\
\text { subsidies, loans, arrears, etc.) }\end{array}$ & Monthly & $\begin{array}{l}20^{\text {th }} \text { of the month for the } \\
\text { previous month's data }\end{array}$ \\
\hline $\begin{array}{l}\text { Fuel products } \\
\text { pricing data }\end{array}$ & $\begin{array}{l}\text { International oil prices, domestic fuel prices and their } \\
\text { components, budgetary transfers to SONARA, and SONARA } \\
\text { net financial result, using the format of Table } 2 \text { below. }\end{array}$ & Monthly & $\begin{array}{l}20^{\text {th }} \text { of the month for the } \\
\text { previous month's data }\end{array}$ \\
\hline \multirow[t]{7}{*}{$\begin{array}{l}\text { Real sector } \\
\text { data }\end{array}$} & Consumer price index, Yaoundé and Douala & Monthly & $\begin{array}{l}20^{\text {th }} \text { of the month for previous } \\
\text { month's data }\end{array}$ \\
\hline & National consumer price index & Quarterly & $\begin{array}{l}\text { Six weeks after the end of the } \\
\text { quarter concerned }\end{array}$ \\
\hline & Index of industrial production & Quarterly & $\begin{array}{l}\text { Two months after the end of } \\
\text { the preceding quarter }\end{array}$ \\
\hline & \multicolumn{3}{|l|}{ National accounts } \\
\hline & Flash series & Annual & $\begin{array}{l}\text { Eight months after the end of } \\
\text { the year }\end{array}$ \\
\hline & Provisional series & Annual & $\begin{array}{l}\text { Eighteen months after the end } \\
\text { of the year }\end{array}$ \\
\hline & Final series & Annual & $\begin{array}{l}\text { Twenty four months after the } \\
\text { end of the year }\end{array}$ \\
\hline \multirow[t]{4}{*}{$\begin{array}{l}\text { Balance of } \\
\text { payments data }\end{array}$} & Imports by use and major export products, trade balance & Monthly & $\begin{array}{l}25 \text { th of the month for the } \\
\text { previous month }\end{array}$ \\
\hline & $\begin{array}{l}\text { Preliminary price and volume indices of imports and of } \\
\text { exports }\end{array}$ & Quarterly & $\begin{array}{l}\text { One month after the end of the } \\
\text { quarter concerned }\end{array}$ \\
\hline & Final price and volume indices of imports and exports & Quarterly & $\begin{array}{l}\text { Three months after the end of } \\
\text { the quarter concerned }\end{array}$ \\
\hline & Balance of payments & Annual & $\begin{array}{l}\text { Six months after the end of the } \\
\text { year for the preliminary series } \\
\text { Twelve months after the end } \\
\text { of the year for the final series }\end{array}$ \\
\hline
\end{tabular}




\section{Table 1. Cameroon: Data-Reporting Requirements (concluded)}

$\begin{array}{llll}\begin{array}{l}\text { Category of } \\ \text { Data } \\ \begin{array}{l}\text { External debt } \\ \text { data }\end{array}\end{array} & \begin{array}{l}\text { Table/Report } \\ \text { Stock of outstanding debt and arrears }\end{array} & \begin{array}{l}\text { Frequency } \\ \text { At least } \\ \text { annual }\end{array} & \begin{array}{l}\text { Target Date } \\ \text { At the beginning of the year; } \\ \text { updates as needed }\end{array} \\ & \text { Debt service due after debt relief } & \text { Monthly } & \begin{array}{l}25^{\text {th }} \text { of the month for the } \\ \text { previous quarter's data } \\ 25^{\text {th }} \text { of the month for the } \\ \text { previous month's data } \\ 25^{\text {th }} \text { of the month for the } \\ \text { previous month's data }\end{array} \\ & \begin{array}{l}\text { New grants and loans received, specified by creditor including } \\ \text { their terms and conditions and project }\end{array} & \text { Monthly } & \begin{array}{l}25^{\text {th }} \text { of the month for the } \\ \text { previous quarter's data }\end{array}\end{array}$




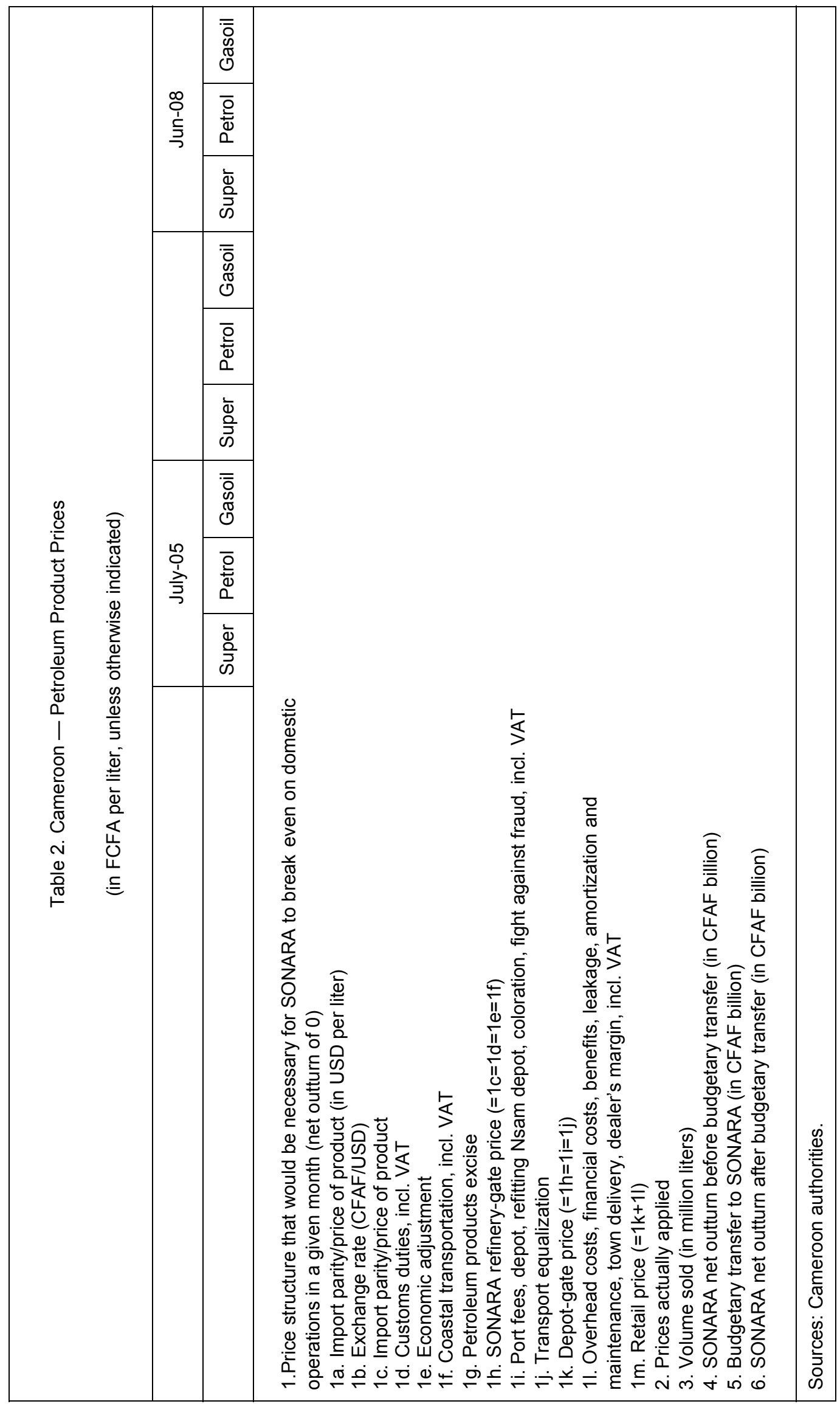




\title{
INTERNATIONAL MONETARY FUND
}

\section{CAMEROON}

Fifth Review Under the Three-Year Arrangement Under the Poverty Reduction and Growth Facility, Financing Assurances Review, and Requests for Waiver of Performance Criterion, Modification of Performance Criteria and Extension of Arrangement-Informational Annex

\author{
Prepared by the African Department
}

Approved by David Nellor and Adnan Mazarei

June 5, 2008

Contents

Annexes

I. Relations with the Fund ..........................................................................................2

II. Relations with the World Bank ..............................................................................

III. Table of Common Indicators Required for Surveillance ............................................. 13 


\section{Cameroon: Relations with the Fund}

(As of April 30, 2008)

I. Membership Status: Joined 07/10/1963; Article VIII

II. General Resources Account:

Quota

Fund holdings of currency

Reserve position in Fund

III. SDR Department:

Net cumulative allocation

Holdings

IV. Outstanding Purchases and Loans:

PRGF arrangements

V. Latest Financial Arrangements:

$\begin{array}{ccccc}\text { Type } & \begin{array}{c}\text { Date of } \\ \text { Arrangement }\end{array} & \begin{array}{c}\text { Expiration } \\ \text { date }\end{array} & \begin{array}{c}\text { Amount approved } \\ \text { (SDR million) }\end{array} & \begin{array}{c}\text { Amount drawn } \\ \text { (SDR million) }\end{array} \\ \text { PRGF } & 10 / 24 / 2005 & 10 / 23 / 2008 & 18.57 & 13.25 \\ \text { PRGF } & 12 / 21 / 2000 & 12 / 20 / 2004 & 111.42 & 79.59 \\ \text { PRGF } & 08 / 20 / 1997 & 12 / 20 / 2000 & 162.12 & 162.12\end{array}$

SDR million $\quad$ \%Quota

185.70

100.00

99.57

0.43

$\underline{\text { SDR million }}$

24.46

\%Allocation

100.00

12.39

$\frac{\% \text { Quota }}{7.14}$ $\underline{\text { SDR million }}$

13.25 
VI. Projected Payments to Fund (SDR million; based on existing use of resources and present holdings of SDRs)

Forthcoming

\begin{tabular}{|c|c|c|c|c|c|}
\hline & $\underline{2008}$ & $\underline{2009}$ & $\underline{2010}$ & $\underline{2011}$ & $\underline{2012}$ \\
\hline Principal & & & & 0.80 & 1.59 \\
\hline Charges/interest & 0.51 & 0.65 & 0.65 & 0.65 & 0.64 \\
\hline Total & 0.51 & 0.65 & 0.65 & 1.45 & 2.24 \\
\hline
\end{tabular}

VII. Implementation of HIPC Initiative:

I. Commitment of HIPC assistance

Enhanced

framework

Decision point date

Oct 2000

Assistance committed ${ }^{1}$

By all creditors (US\$ million)

$1,267.00$

Of which: Fund assistance (US\$ million)

37.04

(SDR equivalent in millions)

28.62

Completion point date

Apr 2006

II. Delivery of Fund assistance (SDR million)

Amount disbursed

28.62

Interim assistance

11.25

Completion point

17.37

Additional disbursement of interest income ${ }^{2}$

Total disbursements

${ }^{1}$ Assistance committed under the original framework is expressed in net present value (NPV) terms at the completion point, and assistance committed under the enhanced framework is expressed in NPV terms at the decision point. Hence these two amounts can not be added.

${ }^{2}$ Under the enhanced framework, an additional disbursement is made at the completion point corresponding to interest income earned on the amount committed at the decision point but not disbursed during the interim period. 
VIII. Implementation of MDRI Assistance:

I. $\quad$ MDRI-eligible debt (SDR million) ${ }^{1} \quad 173.26$

Financed by: MDRI Trust $\quad 149.17$

Remaining HIPC Resources $\quad 24.09$

II. Debt Relief by Facility (SDR million)

Eligible Debt

$\begin{array}{llll}\frac{\text { Delivery }}{\text { Date }} & \frac{\text { GRA }}{\text { Npril } 2006} & \underline{\text { PRGF }} & \underline{\text { Total }} \\ & \text { N } & \end{array}$

${ }^{1}$ The MDRI provides 100 percent debt relief to eligible member countries that qualified for the assistance. Grant assistance from the MDRI Trust and HIPC resources provide debt relief to cover the full stock of debt owed to the Fund as of end-2004 that remains outstanding at the time the member qualifies for such debt relief.

\section{Safeguards Assessments:}

The Bank of the Central African States (BEAC) is the regional bank of Central African States of which Cameroon is a member. The most recent safeguards assessment of the BEAC was completed on August 30, 2004. The assessment found that the Bank has implemented a number of measures to strengthen its safeguards framework since the 2001 safeguards assessment in the areas of external and internal audits, and financial reporting. A summary of the recommendations of the safeguards assessment was reported in Country Report No. 7/129.

The latest monitoring results, obtained in 2007, indicate the existence of certain vulnerabilities in key areas, especially in terms of implementation of an internationally accepted accounting framework and establishment of strong internal control systems. Documentation for a new update safeguards assessment of BEAC has been requested on April 18, 2008.

\section{Exchange Arrangements:}

Cameroon participates in a currency union with five other members of the CEMAC and has no separate legal tender. Cameroon's currency, the CFA franc, is pegged to the euro at the fixed rate of CFAF 655.957 per euro. Local currency equivalent: CFAF 706.7 = SDR 1, as of November 30, 2007. Effective January 1, 2007, the exchange arrangement of the CEMAC countries has been reclassified to the category of conventional pegged arrangement from the category of exchange arrangement with no separate legal tender. The new classification is based on the behavior of the common currency, whereas the previous classification was based on the lack of a separate legal tender. The new classification thus reflects only a 
definitional change, and is not based on a judgment that there has been a substantive change in the exchange regime or other policies of the currency union or its members.

Cameroon maintains an exchange system free of restrictions on the making of payments and transfers for current international transactions, except for restrictions maintained for security reasons that have been notified to the Fund pursuant to Executive Board decision 144$152 / 51$.

\section{Article IV Consultation:}

The last Article IV consultation with Cameroon was concluded by the Executive Board on June 18, 2007.

\section{FSAP Participation and ROSCs:}

The Financial System Stability Assessment (FSSA) report of May 24, 2000 is based on the findings of the joint IMF-World Bank mission that visited Cameroon during February 29March 14, 2000. The findings of the Financial Sector Assessment Program (FSAP) mission were presented to the authorities on March 13-14, 2000 in the context of the 2000 Article IV consultation. An updated assessment was carried out by a joint IMF-World Bank FSAP mission in June 2007.

The Report on the Observance of Standards and Codes (ROSC) on fiscal transparency and transparency of monetary and financial policies was issued on June 16, 2000.

The data module of the ROSC was issued on August 24, 2001 (CR/01/150).

\section{Technical Assistance:}

April 2008: FAD mission on the implementation of the new organic law.

April 2008: FAD mission on tax administration modernization.

September 2005-April 2008: presence of an FAD resident expert for fiscal administration (shared with other countries in the region).

October 2006: FAD mission on poverty and social impact assessment of the current petroleum price mechanism.

October 2006: FAD mission (jointly with World Bank) to assess preparation of the new organic budget law, and review expenditure classification system. 
March 2006: STA mission on balance of payments statistics compilation.

July 2005: FAD mission on tax policy.

May 2005: FAD mission on tax and customs administration.

December 2004: STA mission on the compilation of national accounts and follow-up by FAD expert on public expenditure management.

October 2003: STA mission on the compilation of national accounts.

September 2003: FAD mission on non-oil revenue mobilization and follow-up by FAD expert on public expenditure management.

June 2003: FAD mission on public expenditure management.

March 2003: FAD mission on public expenditure management.

November 2002: FAD mission on public expenditure management.

May 2002: FAD mission on public expenditure management.

April 2002: FAD mission follow-up on the personal income tax system.

March 2002: FAD mission on the implementation of the action plan for government revenue and expenditure.

October-November 2001: FAD mission on tax and customs administration.

September 2001: FAD missions on the audit of the treasury and poverty tracking.

June 2000: FAD mission on the modernization of customs.

April 2000: STA mission on General Data Dissemination System (GDDS/ROSC).

November 1999: FAD mission on modernization of the tax department.

June-July 1999: FAD technical assistance mission on customs.

May-June 1999: FAD follow-up mission on value-added tax (VAT) and tax administration. January-March 1999: Placement of an FAD advisor for the introduction of the VAT. 
November 1998: Placement of an FAD resident advisor on public expenditure management.

October-November 1998: STA mission on metadata project.

September 1998: Placement of FAD advisor for the VAT.

July 1998: FAD mission on preparation of a VAT.

February 1998: FAD technical assistance mission on review of public expenditure management.

November 1997: FAD technical assistance mission on preparation for the introduction of the VAT.

January-February 1997: AFR/PDR mission, in collaboration with experts from the World Bank and the French government, on external debt statistics.

May 1996: AFR mission, in collaboration with a team from the French Treasury and the Banque de France, on the system of fiscal reporting and monitoring.

February 1996: FAD mission on direct taxation and agricultural sector taxation.

May-June 1995: STA mission on balance of payments statistics.

XIV. Resident Representatives:

The post of IMF Resident Representative has been maintained in Yaoundé continuously since 1989. The current Resident Representative, Ms. Kabedi-Mbuyi, has been in her post since July 2005. 


\section{Cameroon: Relations with the World Bank}

(As of May 15, 2008)

\section{Government's Strategy Supported by the World Bank}

1. The government's strategy for economic growth and poverty reduction, as described in the poverty reduction strategy paper (PRSP) communicated to the World Bank and the IMF in April 2003, is articulated along seven pillars, as detailed in IDA/SecM2003-0434. The Government has begun revising the PRSP, with an expected completion date of early 2008.

\section{World Bank Lending and Strategy}

2. A joint IDA-IFC Interim Strategy Note (ISN) was presented to the Board on December 7, 2006. The strategy, which covers fiscal year (FY) 07-08, maintains the broad objectives of the previous Country Assistance Strategy but with enhanced emphasis on governance including combating corruption, managing for results, and strengthening partnerships, and alignment and harmonization of external assistance in line with the Paris Declaration for aid effectiveness. World Bank's support to the Government's strategy is integrated around six proposed outcomes:

3. Strengthening PRSP implementation: Planned activities include policy dialogue and technical assistance to support revision of the PRSP, with a focus on sharpened priorities and an explicit results framework, including monitoring and evaluation mechanisms.

4. Strengthening governance, including anticorruption and public finance management: Activities include planned financing of an operation to increase transparency and accountability as well as planned programmatic support to strengthen public financial management as part of a multi-donor platform; ongoing policy dialogue and technical assistance to support implementation of the Extractives Industries Transparency Initiative (EITI); and support to anticorruption efforts. Corruption assessments will be conducted in key sectors as part of a coordinated support effort by international partners initiated by the Bank and linked to OECD-DAC efforts to develop a common anticorruption policy. An assessment of corruption in the health sector was completed in July 2007.

5. Fostering private sector development: Activities include enhanced IFC support to small enterprises; stepped-up IFC/Bank policy dialogue and technical assistance to strengthen Cameroon's weak business climate, including through a jointly appointed senior IFC/Bank staff based in Cameroon; and support to tighter regional integration, through an ongoing regional payment systems operation and a planned operation to strengthen regional financial institutions. 
6. Supporting infrastructure and urban development: Activities include ongoing financing of the Douala infrastructure, the railway concession, the regional air transport safety and security operations, an urban and water development project, and a regional transport and trade facilitation operation; as well as a planned energy sector operation and an ongoing policy dialogue on energy issues.

7. Supporting the forestry and environment sectors and strengthening rural and agricultural development: Activities include ongoing financing of the multi-partnersupported forestry and environment program, the community development program, and an operation to strengthen petroleum environment management capacity; an ongoing ESW on forestry reform; and a planned rural investment climate assessment/value chain analysis as key input to the preparation of a Sector-wide approach (SWAp) in the agriculture sector.

8. Promoting human development: Activities include financing of an ongoing operation to increase capacity in the education sector, a planned follow-up multi-sectoral HIV/AIDS operation, and planned support of a SWAp in the health sector (FY08). Within the health SWAp, the Bank expects to provide financial support for capacity building, systems development, and delivery of basic health services: (i) strengthen the normative functions of the Ministry of Health; (ii) reinforce the capacity of provinces to manage, allocate, and plan resources, and to supervise, and monitor districts; and (iii) fund a basic package of services included in a consolidated health district plan which reflects sector priorities based on the updated Health Sector Strategy. The Bank has also completed a fiscal space study in the health sector.

9. As of January 31, 2008, the IDA portfolio (including GEF co-financing) comprises ten active projects with a total commitment of US\$433.8 million, of which US\$311.7 million are not disbursed yet. These projects cover a broad range of sectors, including infrastructure, education, transport, environment, forestry, local development, urban and water supply, and public-private partnerships for growth and poverty reduction. IDA also manages five grants with a total commitment of US\$2.5 million in the areas of governance (EITI), PRSP and health sector project preparation.

\begin{tabular}{|lr|}
\hline \multicolumn{2}{|c|}{ Table 1: World Bank Portfolio in Cameroon } \\
(commitments at January 31, 2008, in US\$ million) \\
IDA Total & $\mathbf{4 3 3 . 8}$ \\
Douala Infrastructure & 56.4 \\
Community development program (IDA + GEF) & 26.0 \\
Public-private partnership for growth & 20.9 \\
BEAC Payment Systems & 14.5 \\
Forest and environment development (IDA+GEF) & 35.0 \\
Urban and water sector development & 80.0 \\
Education & 18.2 \\
Railway Concession & 21.4 \\
Air Transport Safety and Security & 14.5 \\
CEMAC transport and transit facilitation program & 146.9 \\
\hline
\end{tabular}


10. In addition to its lending activities, the World Bank has been supporting the government with analysis and a policy dialogue in such areas as :

- Monitoring and assisting on the PRSP implementation (i) by providing assistance and formulating sector strategies, sector and global medium-term expenditure frameworks to align the national budget to the PRSP development objectives; (ii) carrying out an Investment Climate Assessment (ICA) in FY06 to sharpen PRSP policies for economic growth and diversification, and poverty reduction.

- Strengthening the dialogue and action on the governance agenda with an active role in (i) the Multidonor Platform on Public Finance that is working with the Government on improving public financial management, and (ii) working closely with other partners to support the government's efforts to combat corruption. To support these activities a Public Expenditure Management and Financial Accountability Review (PEMFAR) and a Country Procurement Assessment Review have been undertaken.

\section{IMF-World Bank Collaboration in Specific Areas}

11. The IMF and World Bank staffs collaborate on (i) the HIPC Initiative and the PRSP process and specifically worked jointly on the documents for the HIPC completion point and the JSAN of the PRSP progress report, which were presented to the Boards in April 2006; (ii) analyses and reforms in public financial management; and (iii) other governance reforms, including the customs systems. Table 2 briefly describes each area and the specific policy advice support provided by the two institutions. 
Table 2: Cameroon: Bank/Fund Collaboration

\begin{tabular}{|c|c|c|c|}
\hline Area & Description & $\begin{array}{c}\text { Specialized Advice/ } \\
\text { Reforms Supported by } \\
\text { Fund }\end{array}$ & $\begin{array}{l}\text { Specialized Advice/ Reforms } \\
\text { Supported by Bank }\end{array}$ \\
\hline $\begin{array}{l}\text { Public financial } \\
\text { management }\end{array}$ & $\begin{array}{l}\text { Bank and Fund missions analyzing } \\
\text { aspects of fiscal management }\end{array}$ & $\begin{array}{l}\text { Tax analysis and policies, } \\
\text { strengthening of control } \\
\text { agencies; expenditure } \\
\text { management, including } \\
\text { expenditure classification } \\
\text { treasury management; } \\
\text { transparency and reporting } \\
\text { in budget operations; budget } \\
\text { execution, monitoring and } \\
\text { evaluation }\end{array}$ & $\begin{array}{l}\text { Expenditure policy and budget } \\
\text { allocation; budget planning and } \\
\text { programming, including } \\
\text { preparation of global and sector } \\
\text { MTEFs; budget execution } \\
\text { evaluation } \\
\text { Public procurement reform } \\
\text { Budget tracking in key sectors }\end{array}$ \\
\hline $\begin{array}{l}\text { Other governance } \\
\text { reforms }\end{array}$ & $\begin{array}{l}\text { Coordination of Bank/Fund staff work } \\
\text { with UNDP on developing } \\
\text { implementation plans }\end{array}$ & Customs and tax reform & $\begin{array}{l}\text { Anticorruption agenda; } \\
\text { Decentralization } \\
\text { EITI }\end{array}$ \\
\hline Structural reforms & $\begin{array}{l}\text { Continuation of the structural reforms } \\
\text { required to sustain growth }\end{array}$ & $\begin{array}{l}\text { Trade policies; financial } \\
\text { sector reform }\end{array}$ & $\begin{array}{l}\text { Reforms in education, health, } \\
\text { transport, energy, rural } \\
\text { infrastructure, and urban } \\
\text { development } \\
\text { Restructuring and privatization of } \\
\text { public enterprises, including } \\
\text { CAMAIR, CAMTEL, SNEC, and } \\
\text { CAMPOST } \\
\text { Institutional and human capacity } \\
\text { building, including civil service } \\
\text { reform (pay issues) } \\
\text { Private sector development and } \\
\text { trade and transit policies } \\
\text { Financial sector strategy }\end{array}$ \\
\hline $\begin{array}{l}\text { HIPC completion } \\
\text { point and PRSP } \\
\text { related activities }\end{array}$ & $\begin{array}{l}\text { Joint tracking of HIPC- related spending } \\
\text { and the preparation of the HIPC } \\
\text { completion point documents and JSAN } \\
\text { of PRSP progress reports }\end{array}$ & & \\
\hline
\end{tabular}


12. The Fund takes the lead on policy advice and reforms related to (i) macroeconomic policy and short- and medium-term financial programming; (ii) tax policy and administration; (iii) information and financial management systems for government revenue; (iv) budget accounting; (v) treasury procedures; and (vi) expenditure classification and tracking. Bank staffs participate in the meetings of Fund missions with the authorities in these areas.

13. The World Bank takes the lead on (i) institutional and human capacity building for public sector management; (ii) anticorruption; (iii) budget planning and programming including formulation of sectoral strategies and medium-term expenditure frameworks; (iv) EITI implementation; (v) analysis of poverty and sources of growth to support the PRSP process, (vi) advice on sector development particularly the social sectors, infrastructure, agriculture, and forestry; (vii) the design, implementation and monitoring of the structural reform program including the privatization of public enterprises; and (viii) decentralization agenda.

14. Both the Bank and Fund have responsibility for policy advice on (i) budgetary procedures, government expenditure management systems, and expenditure execution, including tracking of poverty-reducing expenditures; (ii) the functioning of internal and external budget control institutions; (iii) customs reform; (iv) financial system reform; and (v) governance. The two institutions also jointly support and monitor the HIPC Initiative and PRSP process. Finally, the Bank and the Fund have jointly conducted a FSAP for the CEMAC region, and a joint FSAP for Cameroon.

Questions may be addressed to Abdoulaye Seck (Tel. 237-2220-3815) or Katrina Sharkey (Tel. 473-6288). 


\section{Cameroon: Table of Common Indicators Required for Surveillance}

(as of May 15, 2008)

\begin{tabular}{|c|c|c|c|c|c|}
\hline & $\begin{array}{l}\text { Date of latest } \\
\text { observation }\end{array}$ & $\begin{array}{l}\text { Date } \\
\text { received }\end{array}$ & $\begin{array}{l}\text { Frequency } \\
\text { of } \\
\text { Data }^{7}\end{array}$ & $\begin{array}{l}\text { Frequency } \\
\text { of } \\
\text { Reporting }^{7}\end{array}$ & $\begin{array}{l}\text { Frequency } \\
\text { of } \\
\text { publication }^{7}\end{array}$ \\
\hline Exchange Rates & Apr . 2008 & May 2008 & M & M & M \\
\hline $\begin{array}{l}\text { International Reserve Assets and Reserve } \\
\text { Liabilities of the Monetary Authorities }{ }^{1}\end{array}$ & Dec. 2007 & Mar. 2008 & M & M & M \\
\hline Reserve/Base Money & Jan. 2008 & Apr. 2008 & M & M & M \\
\hline Broad Money & Jan. 2008 & Apr. 2008 & M & M & M \\
\hline Central Bank Balance Sheet & Jan. 2008 & Apr. 2008 & M & M & M \\
\hline $\begin{array}{l}\text { Consolidated Balance Sheet of the Banking } \\
\text { System }\end{array}$ & Jan. 2008 & Apr. 2008 & M & M & M \\
\hline Interest Rates ${ }^{2}$ & Jan. 2008 & Apr. 2008 & M & M & M \\
\hline Consumer Price Index & Mar. 2008 & May 2008 & M & Q & Q \\
\hline $\begin{array}{l}\text { Revenue, Expenditure, Balance and } \\
\text { Composition of Financing }{ }^{3}-\text { General } \\
\text { Government }^{4}\end{array}$ & NA & NA & NA & NA & NA \\
\hline $\begin{array}{l}\text { Revenue, Expenditure, Balance and } \\
\text { Composition of Financing }{ }^{3}-\text { Central } \\
\text { Government }\end{array}$ & Dec. 2007 & Feb. 2008 & M & M & $\begin{array}{l}\text { Partial data } \\
\text { published } \\
\text { monthly. }\end{array}$ \\
\hline $\begin{array}{l}\text { Stocks of Central Government and Central } \\
\text { Government-Guaranteed Debt }\end{array}$ & Dec. 2007 & Jan. 2008 & M & M & M \\
\hline External Current Account Balance & 2004 & Oct. 2007 & A & A & NA \\
\hline Exports and Imports of Goods and Services ${ }^{6}$ & Dec. 2007 & Mar. 2008 & M & M & NA \\
\hline GDP/GNP & Dec. 2006 & Sept. 2007 & A & A & NA \\
\hline Gross External Debt & $\mathrm{N} / \mathrm{A}$ & $\mathrm{N} / \mathrm{A}$ & N/A & N/A & $\mathrm{N} / \mathrm{A}$ \\
\hline
\end{tabular}

${ }^{1}$ Includes reserve assets pledged or otherwise encumbered as well as net derivative positions.

${ }^{2}$ Both market-based and officially determined, including discount rates, money market rates, rates on treasury bills, notes and bonds.

${ }^{3}$ Foreign, domestic bank, and domestic nonbank financing.

${ }^{4}$ The general government consists of the central government (budgetary funds, extra budgetary funds, and social security funds) and state and local governments.

${ }^{5}$ Including currency and maturity composition.

${ }^{6}$ Goods only, data on trade in services are not available.

${ }^{7}$ Daily (D), Weekly (W), Monthly (M), Quarterly (Q), Annually (A), Irregular (I); Not Available (NA). 


\section{INTERNATIONAL MONETARY FUND AND \\ INTERNATIONAL DEVELOPMENT ASSOCIATION}

\section{CAMEROON}

\section{Joint IMF/World Bank Debt Sustainability Analysis}

Prepared by the Staffs of the International Monetary Fund and the World Bank

Approved by David Nellor and Adnan Mazarei (IMF) and Carlos Braga and Sudhir Shetty (World Bank)

June 5, 2008

This note assesses the sustainability of Cameroon's external public debt and total public debt based on the joint IMF-World Bank debt sustainability framework for low-income countries. ${ }^{1}$ Although Cameroon has been downgraded to a "weak policy performer" based on the most recent CPIA data, its external debt remains at a low risk of debt distress. Public debt indicators are also expected to remain low throughout the projection period.

\section{BACKGROUND}

1 Following debt relief under the enhanced HIPC initiative and MDRI, Cameroon's debt-related indicators fell substantially below the indicative policy-dependent thresholds. Cameroon reached the completion point under the enhanced HIPC Initiative in April 2006. As a result, total public debt_-external and domestic_-declined from US\$ 8.5 billion in 2005 to US\$ 2.8 billion in 2006 (or from 51.5 to 15.5 percent of GDP). At end-2007, Cameroon's external and domestic debt amounted to at US\$ 2.6 billion (or 12.4 percent of GDP); external debt continues to be dominated by official bilateral creditors (chart).

\begin{tabular}{|c|c|c|c|c|c|c|}
\hline & \multicolumn{6}{|c|}{ Cameroon: Stock of Public Debt, 2006-2007 } \\
\hline & \multicolumn{2}{|c|}{ In million of US\$ } & \multicolumn{2}{|c|}{ In percent of total } & \multicolumn{2}{|c|}{ In percent of GDP } \\
\hline & 2006 & 2007 & 2006 & 2007 & 2006 & 2007 \\
\hline Total & 2,779 & 2,563 & 100.0 & 100.0 & 15.5 & 12.4 \\
\hline External debt & 1,069 & 1,131 & 38.5 & 44.1 & 6.0 & 5.5 \\
\hline Domestic debt & 1,710 & 1,432 & 61.5 & 55.9 & 9.5 & 6.9 \\
\hline
\end{tabular}

\footnotetext{
1 “Operational Framework for Debt Sustainability Assessments in Low-Income Countries - Further Considerations”.
} 

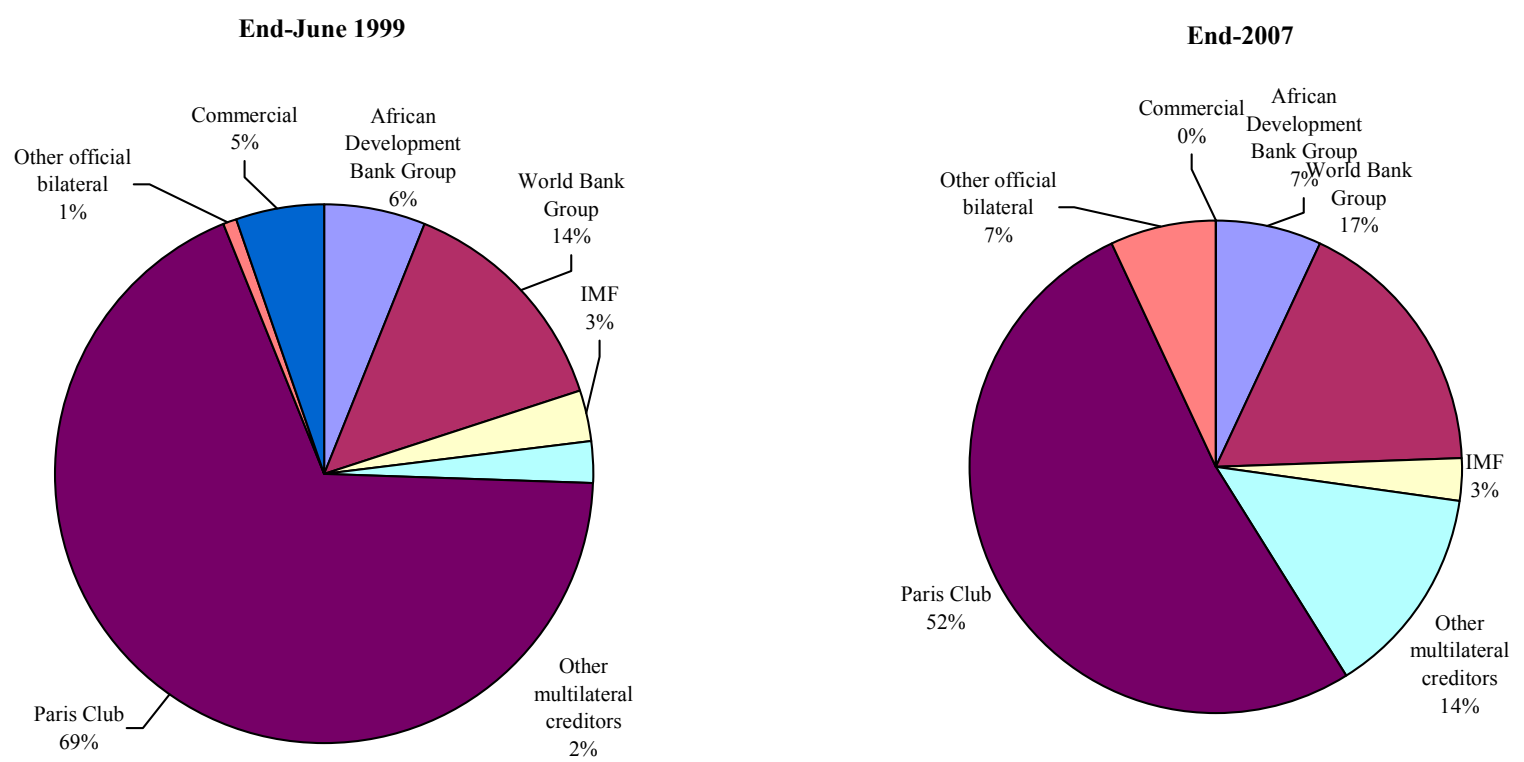

Sources: Cameroonian authorities; and IDA and IMF staff estimates and projections.

2 The DSA is based on data provided by Cameroon's main multilateral creditors and by the authorities on the remaining creditors. Data quality on Cameroon's public debt has improved but remains uneven, in particular on private sector and non-guaranteed public enterprise debt (Figure 1). The DSA does not take into account contingent liabilities due to data limitations. The existence of such liabilities for public enterprises and parastatals would increase Cameroon's domestic debt stock.

3 The authorities have signed debt-relief agreements with bilateral and commercial creditors. All bilateral agreements with Paris Club and non-Paris Club creditors have been signed following the completion point. Significant progress was also made with the London Club of commercial creditors. Agreements are still pending with three commercial creditors holding claims totaling about US\$91 million, which the authorities expect to finalize in 2008, in line with Cameroon's commitment s to the Paris Club. The government is seeking to obtain terms comparable to those of the enhanced HIPC Initiative. Nevertheless, some private creditors have insisted on the full repayment of the principal while agreeing to forgo accumulated interest and penalties.

4 Cameroon's public debt has declined considerably in recent years. The decrease is driven by large cancellations of external debt and frontloaded domestic debt repayments. Building on the results of comprehensive audit for the end-2004 stock of domestic debt, the government repaid substantial amounts, which helped reduce domestic debt from 17 percent of GDP in 2004 to 7 percent of GDP by end-2007. The debt repayment plan prepared by the authorities implies substantial additional repayments of domestic debt in the next several years, 
lowering further the domestic debt to 4 percent of GDP. This outstanding stock of domestic debt is conducive to developing a domestic debt market, as suggested in the recent FSAP.

\section{Methodology and Key Macroeconomic Assumptions}

5 The staff examined Cameroon's external public debt stock and debt service profile under a baseline scenario and a series of stress tests, following the guidelines of the LIC debt sustainability framework. ${ }^{2}$ The stress tests are designed to assess the probability of a country facing debt distress in the future under standard shocks.

6 The analysis is guided by indicative, performance-based debt burden thresholds for external debt. The latter take into account the empirical finding that the debt levels that a low-income country can sustain increase with the quality of its policies and institutions. The quality of policies and institutions is measured by the Country Policy and Institutional Assessment (CPIA) index, compiled annually by the World Bank. Cameroon now ranks as a 'weak performer' under the joint IMF/World Bank debt sustainability framework, based on its three-year moving average CPIA score. ${ }^{3}$ The indicative external debt burden thresholds for countries in this category are an NPV of debt-to-exports ratio of 100 percent, NPV of debt-torevenue ratio of 200 percent, a NPV of debt-to-GDP ratio of 30 percent, and debt-service-toexports and revenues ratios of 15 and 25 percent, respectively.

7 Cameroon's medium-term framework assumptions are described in Box 1. Real GDP growth will continue to pick up over the medium term, reflecting increased investment and structural reform implementation. The current account deficit will deteriorate over the medium-term, but will then gradually improve over the longer term. Fiscal policy would be supportive of economic growth and poverty reduction, although over the medium-term the nonoil primary balance (program definition) is expected to deteriorate, reflecting considerable social and infrastructure needs. New public borrowing is assumed to increase gradually over the medium term to help finance new investment.

\footnotetext{
2 "Staff Guidance Note on the Application of the Joint Fund-Bank Debt Sustainability Framework for Low-Income Countries."

${ }^{3}$ Cameroon's CPIA declined from 3.3 to 3.2 in 2006 and remained at that level in 2007, thus bringing the country in the group of 'weak' policy performers. The downgrade is the result of deterioration in the following criteria: business regulatory environment; policies and institutions for environmental sustainability; and efficiency of revenue mobilization.
} 


\section{Box 1. Main Macroeconomic Assumptions, 2008-28}

Real GDP growth is expected to accelerate to just over 5 percent in 2012 reflecting economic stimulus from increased capital spending, and the implementation of structural reforms. Over the longer-term, growth in the non-oil economy is expected to stabilize at about $5 \frac{1}{2}$ percent, while oil GDP will gradually decline. Investment is expected to rise to about 22 percent of GDP over the medium term, a level supportive of long-term economic growth. The average non-oil growth rate over the entire projection period is 51/2 percent, somewhat higher than the 10 -year average of about 4 percent during 1997-2007.

Inflation is assumed to hold steady at 2 percent over the long-term, in line with recent historical experience and reflecting the regional central bank's commitment to keep inflation under control.

Government revenues are projected to decline over time as a result of declining oil proceeds. Nonoil revenues are expected to rise from about 12/1/2 percent of GDP in 2007 to about 16 percent at the end of the projection period, reflecting sustained implementation of measures to strengthen tax and customs administrations.

Government expenditure is expected to rise over the medium-term to about 19 percent of GDP. This path is consistent with a gradual increase in capital expenditure over the medium-term, control of current spending growth, and a rise in pro-poor spending.

Current account deficit, including grants, is expected to rise gradually to about 5 percent of GDP by 2019 and then gradually decline, in part driven by higher imports. Despite a gradual decline in petroleum exports, overall exports are expected to remain high. The deficit is expected to be financed through foreign direct investment and loans, a mixture of which will be from IDA and the rest from other creditors on less concessional terms

External borrowing is expected to rise gradually to 1.8 percent of GDP over the medium term (compared to an average of 0.8 percent of GDP during 2001-07) and then to decline gradually to about 1 percent in the outer years. IDA borrowing is assumed to constitute 24 percent of new borrowing per year, with the remainder originating from other multilateral and bilateral creditors on less concessional terms. Assuming that Cameroon will cross the IDA-only threshold in 2010, disbursements from the Bank will also be on less concessional terms.

\section{EXTERnAL DebT SustainabiLity}

8 Cameroon' external debt indicators are expected to remain below their respective indicative thresholds throughout the projection period (Table $1 \mathrm{~b}$ and Figure 2). Although debt indicators would increase over the longer term, reflecting additional borrowing to meet the country's development needs and reduced concessionality from 2011 onwards, the sustainability thresholds on external debt are not breached under the baseline scenario 
throughout the projection period. ${ }^{4}$ The same conclusion holds for the other alternative scenarios. While the baseline scenario appears to be rather conservative relative to the historical scenario, it should be noted that the historical scenario reflects past current account surpluses that are not likely in the future given the expected decline in oil production. Consequently, the country's external debt burden indicators seem more optimistic under the historical average scenario than under the baseline scenario. Results under the historical scenario were therefore excluded from Figure 2, as they are less informative about possible sources of debt distress. Under the scenario of new borrowing on less concessional terms, which assumes that the interest rate on new borrowing through 2028 is two percentage points higher than in the baseline, all debt ratios will start deteriorating, but none of them, will exceed the indicative thresholds.

9 In the presence of adverse exogenous shocks, all debt indicators remain below their indicative thresholds. Under the scenario of new borrowing on less concessional terms, which assumes that the interest rate on new borrowing in 2008-2028 is two percentage points higher than in the baseline, all debt ratios will start deteriorating, but none of them will exceed the indicative thresholds. Applying the standardized bound tests to the baseline scenario, under the most extreme stress tests, debt indicators would remain below their thresholds throughout the 2008-28 period, while debt service indicators remain below their indicative threshold throughout the 2008-28 period. In particular, if real growth in 2009-10 were one standard deviation below its historical average, the government would be assumed to close the ensuing financing need through borrowing. Hence, the NPV of debt-to-GDP ratio rises steadily over time and eventually levels off. If export growth in 2009-10 were one standard deviation below its historical average, the NPV of debt-to-exports and the debt service-to-exports ratios would rise above the baseline leveling off towards the end of the projection period.

10 The risk of debt distress in Cameroon remains low as in the previous DSA, based on the results of the alternative scenarios and bound tests, and the fact that the policy indicative thresholds are not exceeded.

\section{Public DebT Sustainability}

11 The long-term fiscal strategy is consistent with preserving the overall public debt sustainability. Under the program agreed with the authorities, the nonoil primary deficit is expected to deteriorate over the medium term in support of the country's development needs. New borrowing will amount to 1.7 percent of GDP annually during 2008-16, consistent with the country's absorption capacity and will then gradually decline over the long-term.

12 Cameroon's public debt under the baseline scenario will rise gradually over the long-term. Under the assumptions in the baseline scenario, the NPV of public debt in percent

\footnotetext{
${ }^{4}$ The residual mainly captures private capital flows.
} 
of revenues is expected to rise over time with some reduction in the outer years. Debt service is expected to rise modestly over time but will remain at comfortable levels. However, any debt that has not been identified by the authorities would increase the risk of debt distress. This could include unaccounted quasi-fiscal liabilities from loss making public enterprises. A new comprehensive audit may be necessary to update the stock of domestic debt.

13 Cameroon's public debt outlook is robust in case of shocks (Table $2 b$ and Figure 3 ). Under the permanently lower GDP scenario, the NPV of debt-to-revenue ratio is considerably higher compared to the baseline scenario. Similarly, if GDP growth in 2009-10 is assumed to be below the historical average by one standard deviation, the long-term debt indicators deteriorate significantly, but remain below the threshold. These outcomes highlight the importance of stepped up efforts to improve growth performance.

\section{The absence of a comprehensive public debt strategy and weak domestic debt} management may pose risks to the outlook. The authorities have already prepared a preliminary draft debt strategy, which is expected to be finalized by end-2008; they will benefit from technical assistance in this regard from the IMF and World Bank. The debt strategy and thus risk assessments are likely to gain in importance, as nonresident investors may increasingly be involved in trading in Cameroon's domestic debt on the secondary market, although so far such transactions have not been significant.

\section{Conclusion}

\section{The LIC-DSA framework indicates that Cameroon faces a low risk of debt}

distress. All external debt indicators remain below the relevant country-specific debt burden thresholds. Alternative scenarios and stress tests reveal an upward trend for the debt indicators but do not result in a breach of the thresholds during the projection period. The risk to public debt is also low, although debt indicators can worsen in the presence of adverse shocks. The lack of a debt management policy may pose a risk to the outlook. However, weak GDP and export growth in the nonoil sector would undermine the recent progress made in achieving macroeconomic and debt sustainability. Thus, maintaining prudent fiscal and borrowing policies, together with the development of a comprehensive public debt management strategy that includes public enterprises and contingent liabilities should be a priority. 


\section{Figure 1. Cameroon: Simplified Debt Structure}

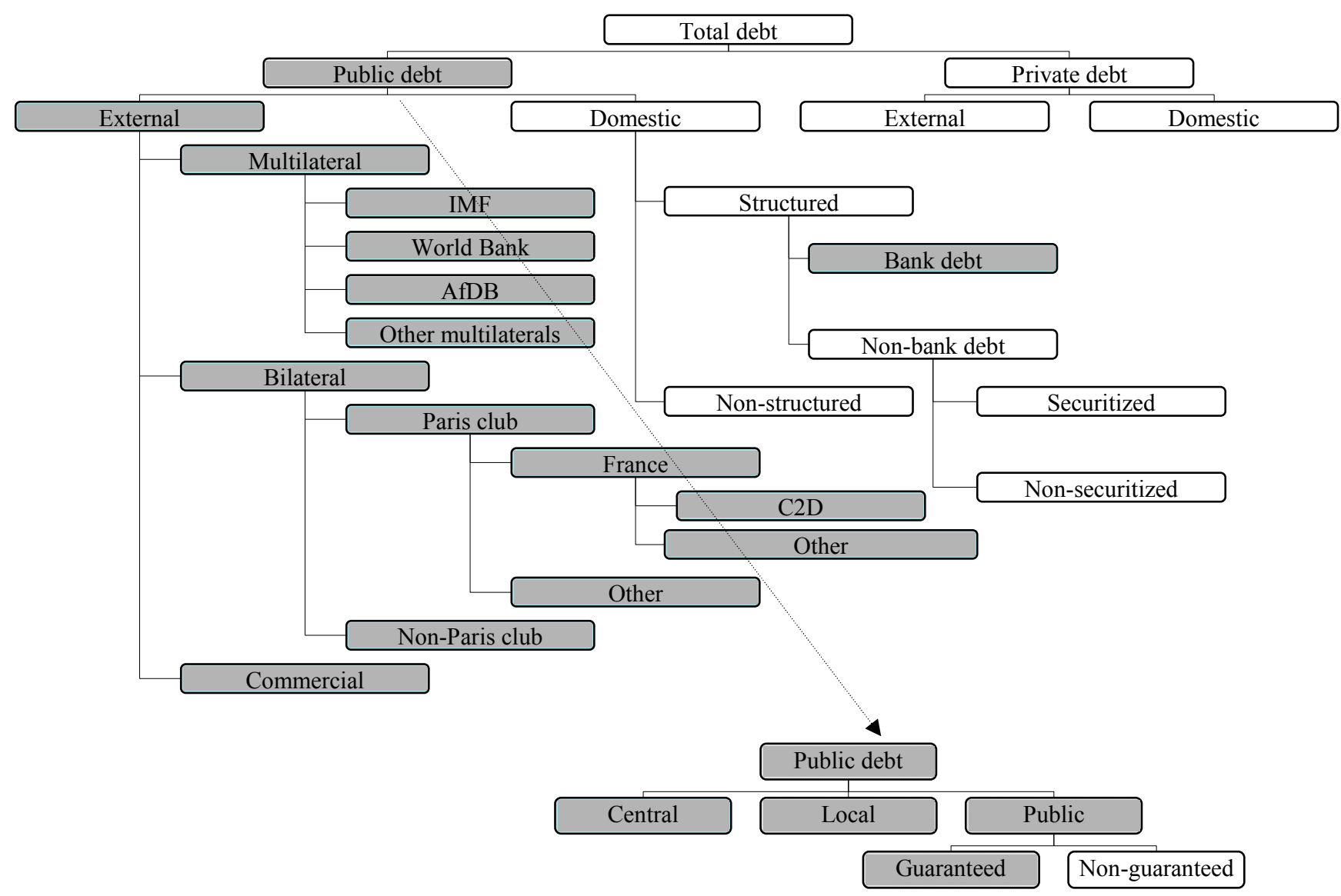

Data available

Partial data available 
Table 1a.. Cameroon: External Debt Sustainability Framework, Baseline Scenario, 2008-2028 1/ (In percent of GDP, unless otherwise indicated)

\begin{tabular}{|c|c|c|c|c|c|c|c|c|c|c|c|c|c|c|c|}
\hline & \multicolumn{3}{|c|}{ Actual } & \multirow{2}{*}{$\begin{array}{c}\text { Historical } \\
\text { Average 6/ }\end{array}$} & \multirow{2}{*}{$\begin{array}{c}\text { Standard } \\
\text { Deviation 6/ }\end{array}$} & \multicolumn{6}{|c|}{ Projections } & \multirow[b]{2}{*}{$2007-12$} & \multirow[b]{2}{*}{2018} & \multirow[b]{2}{*}{2028} & \multirow[b]{2}{*}{$\begin{array}{l}2013-27 \\
\text { Average }\end{array}$} \\
\hline & 2005 & 2006 & 2007 & & & 2008 & 2009 & 2010 & 2011 & 2012 & 2013 & & & & \\
\hline External debt (nominal) 1/ & 37.4 & 6.0 & 5.5 & & & 6.1 & 7.0 & 7.7 & 8.6 & 9.5 & 10.4 & & 13.6 & 10.8 & \\
\hline $\mathrm{o} / \mathrm{w}$ public and publicly guaranteed (PPG) & 37.4 & 6.0 & 5.5 & & & 6.1 & 7.0 & 7.7 & 8.6 & 9.5 & 10.4 & & 13.6 & 10.8 & \\
\hline Change in external debt & -6.8 & -31.4 & -0.5 & & & 0.6 & 0.9 & 0.7 & 0.9 & 0.9 & 0.8 & & 0.3 & -0.6 & \\
\hline Identified net debt-creating flows & 1.1 & -4.2 & -2.0 & & & -2.6 & -1.4 & -0.4 & 0.5 & 1.2 & 2.0 & & 3.3 & 2.7 & \\
\hline Non-interest current account deficit & 2.8 & -1.0 & -0.5 & 1.0 & 2.1 & -1.8 & -0.6 & 0.4 & 1.3 & 2.0 & 2.7 & & 4.1 & 3.2 & 3.8 \\
\hline Deficit in balance of goods and services & 5.0 & 1.1 & 1.8 & & & 0.5 & 1.7 & 2.6 & 3.5 & 4.0 & 4.6 & & 5.7 & 4.2 & \\
\hline Exports & 24.5 & 28.1 & 26.8 & & & 28.5 & 27.5 & 26.0 & 24.5 & 23.2 & 21.9 & & 17.5 & 14.0 & \\
\hline Imports & 29.5 & 29.2 & 28.6 & & & 29.0 & 29.2 & 28.6 & 28.0 & 27.2 & 26.6 & & 23.2 & 18.2 & \\
\hline Net current transfers (negative $=$ inflow) & -1.3 & -1.4 & -1.9 & -1.4 & 0.4 & -1.8 & -1.9 & -1.8 & -1.7 & -1.5 & -1.5 & & -1.1 & -0.6 & -0.9 \\
\hline $\mathrm{o} / \mathrm{w}$ official & 0.0 & 0.0 & 0.0 & & & 0.0 & 0.0 & 0.0 & 0.0 & 0.0 & 0.0 & & 0.0 & 0.0 & \\
\hline Other current account flows (negative $=$ net inflow) & -0.9 & -0.7 & -0.4 & & & -0.5 & -0.5 & -0.5 & -0.5 & -0.5 & -0.5 & & -0.5 & -0.5 & \\
\hline Net FDI (negative $=$ inflow) & -0.1 & -0.7 & -0.8 & -0.3 & 0.3 & -0.7 & -0.6 & -0.6 & -0.5 & -0.5 & -0.4 & & -0.3 & -0.2 & -0.3 \\
\hline Endogenous debt dynamics 2/ & -1.6 & -2.5 & -0.7 & & & -0.1 & -0.2 & -0.2 & -0.2 & -0.3 & -0.3 & & -0.4 & -0.3 & \\
\hline Contribution from nominal interest rate & 0.5 & 0.4 & 0.1 & & & 0.1 & 0.1 & 0.1 & 0.1 & 0.2 & 0.2 & & 0.2 & 0.2 & \\
\hline Contribution from real GDP growth & -1.0 & -1.1 & -0.2 & & & -0.2 & -0.3 & -0.3 & -0.4 & -0.4 & -0.5 & & -0.7 & -0.6 & \\
\hline Contribution from price and exchange rate changes & -1.2 & -1.7 & -0.6 & & & $\ldots$ & $\ldots$ & $\ldots$ & $\ldots$ & $\ldots$ & $\ldots$ & & $\ldots$ & $\ldots$ & \\
\hline Residual (3-4) 3/ & -7.9 & -27.2 & 1.6 & & & 3.2 & 2.3 & 1.1 & 0.4 & -0.3 & -1.1 & & -3.0 & -3.3 & \\
\hline $\mathrm{o} / \mathrm{w}$ exceptional financing & -2.6 & -1.0 & 0.0 & & & 0.0 & 0.0 & 0.0 & 0.0 & 0.0 & 0.0 & & 0.0 & 0.0 & \\
\hline NPV of external debt $4 /$ & $\ldots$ & $\ldots$ & 4.3 & & & 4.6 & 5.2 & 5.5 & 6.2 & 6.8 & 7.5 & & 10.3 & 8.9 & \\
\hline In percent of exports & $\ldots$ & $\ldots$ & 16.0 & & & 16.1 & 18.8 & 21.2 & 25.2 & 29.5 & 34.2 & & 59.0 & 63.6 & \\
\hline NPV of PPG external debt & $\ldots$ & $\ldots$ & 4.3 & & & 4.6 & 5.2 & 5.5 & 6.2 & 6.8 & 7.5 & & 10.3 & 8.9 & \\
\hline In percent of exports & $\ldots$ & $\ldots$ & 16.0 & & & 16.1 & 18.8 & 21.2 & 25.2 & 29.5 & 34.2 & & 59.0 & 63.6 & \\
\hline In percent of government revenues & $\ldots$ & $\ldots$ & 21.6 & & & 21.6 & 23.3 & 25.3 & 29.0 & 33.1 & 36.7 & & 56.0 & 51.6 & \\
\hline Debt service-to-exports ratio (in percent) & 8.6 & 5.2 & 1.0 & & & 1.0 & 1.1 & 1.0 & 1.3 & 1.4 & 1.6 & & 2.8 & 5.7 & \\
\hline PPG debt service-to-exports ratio (in percent) & 8.6 & 5.2 & 1.0 & & & 1.0 & 1.1 & 1.0 & 1.3 & 1.4 & 1.6 & & 2.8 & 5.7 & \\
\hline PPG debt service-to-revenue ratio (in percent) & 11.6 & 3.1 & 1.4 & & & 1.3 & 1.3 & 1.2 & 1.5 & 1.6 & 1.7 & & 2.7 & 4.6 & \\
\hline Total gross financing need (billions of U.S. dollars) & 0.8 & 0.0 & -0.2 & & & -0.5 & -0.2 & 0.0 & 0.3 & 0.6 & 0.9 & & 2.1 & 3.9 & \\
\hline Non-interest current account deficit that stabilizes debt ratio & 9.7 & 30.4 & 0.0 & & & -2.4 & -1.5 & -0.3 & 0.3 & 1.1 & 1.9 & & 3.7 & 3.8 & \\
\hline \multicolumn{16}{|l|}{ Key macroeconomic assumptions } \\
\hline Real GDP growth (in percent) & 2.3 & 3.2 & 3.3 & 3.7 & 1.0 & 4.5 & 4.6 & 4.8 & 5.3 & 5.3 & 5.3 & 5.0 & 5.3 & 5.3 & 5.3 \\
\hline GDP deflator in US dollar terms (change in percent) & 2.8 & 4.8 & 11.3 & 5.3 & 8.5 & 13.6 & 1.3 & 1.7 & 2.5 & 2.8 & 3.1 & 4.2 & 2.0 & 2.0 & 2.0 \\
\hline Effective interest rate (percent) $5 /$ & 1.2 & 1.1 & 1.5 & 3.7 & 2.2 & 2.2 & 1.8 & 1.6 & 2.0 & 2.0 & 2.0 & 1.9 & 2.0 & 2.2 & 2.0 \\
\hline Growth of exports of G\&S (US dollar terms, in percent) & 13.2 & 24.4 & 9.4 & 9.5 & 10.3 & 26.6 & 2.1 & 0.7 & 1.7 & 2.5 & 2.6 & 6.0 & 3.3 & 6.7 & 4.3 \\
\hline Growth of imports of G\&S (US dollar terms, in percent) & 11.4 & 7.3 & 12.4 & 8.4 & 4.2 & 20.5 & 6.6 & 4.4 & 5.5 & 5.2 & 5.9 & 8.0 & 4.4 & 4.8 & 4.8 \\
\hline Grant element of new public sector borrowing (in percent) & $\ldots$ & $\ldots$ & $\ldots$ & $\ldots$ & $\ldots$ & 36.0 & 36.3 & 35.6 & 32.6 & 31.8 & 31.5 & 33.9 & 28.2 & 24.3 & 27.1 \\
\hline Aid flows (in billions of US dollars) 7/ & 0.5 & 0.5 & 0.6 & & & 0.8 & 0.8 & 0.8 & 0.8 & 0.8 & 0.8 & & 0.9 & 0.3 & \\
\hline $\mathrm{o} / \mathrm{w}$ Grants & 0.0 & 0.0 & 0.0 & & & 0.0 & 0.0 & 0.0 & 0.0 & 0.0 & 0.0 & & 0.0 & 0.0 & \\
\hline $\mathrm{o} / \mathrm{w}$ Concessional loans & 0.0 & 0.1 & 0.1 & & & 0.3 & 0.3 & 0.4 & 0.5 & 0.5 & 0.5 & & 0.5 & 0.3 & \\
\hline Grant-equivalent financing (in percent of GDP) $8 /$ & $\ldots$ & $\ldots$ & $\ldots$ & & & 0.7 & 0.7 & 0.6 & 0.6 & 0.5 & 0.6 & & 0.4 & 0.2 & 0.4 \\
\hline Grant-equivalent financing (in percent of external financing) 8/ & $\ldots$ & $\ldots$ & $\ldots$ & & & 39.5 & 41.6 & 38.7 & 34.9 & 31.8 & 31.5 & & 28.2 & 24.3 & 27.1 \\
\hline \multicolumn{16}{|l|}{ Memorandum items: } \\
\hline Nominal GDP (billions of US dollars) & 16.6 & 18.0 & 20.6 & & & 24.5 & 26.0 & 27.7 & 29.9 & 32.3 & 35.1 & & 50.4 & 103.1 & \\
\hline (NPVt-NPVt-1)/GDPt-1 (in percent) & & & & & & 1.2 & 0.9 & 0.7 & 1.2 & 1.2 & 1.3 & 1.1 & 1.1 & 0.3 & 0.8 \\
\hline
\end{tabular}

Source: Staff simulations.

$1 /$ Includes both public and private sector external debt.

2/ Derived as $[\mathrm{r}-\mathrm{g} \rho(1+\mathrm{g})] /(1+\mathrm{g} \phi+\mathrm{g} \rho)$ times previous period debt ratio, with $\mathrm{r}=$ nominal interest rate; $\mathrm{g}=$ real GDP growth $\rho$ ateglandth rate of GDP deflator in U.S. dollar terms.

3/ Includes exceptional financing (i.e., changes in arrears and debt relief); changes in gross foreign assets; and valuation adjustments. For projections also includes contribution from price and

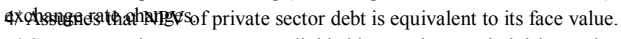

5/ Current-year interest payments divided by previous period debt stock.

6/ Historical averages and standard deviations are generally derived over the past 10 years, subject to data availability.

7/ Defined as grants, concessional loans, and debt relief.

8/ Grant-equivalent financing includes grants provided directly to the government and through new borrowing (difference between the face value and the NPV of new debt). 
Table 1b. Cameroon: Sensitivity Analyses for Key Indicators of Public and Publicly Guaranteed External Debt, 2008-2028

(In percent)

\begin{tabular}{|c|c|c|c|c|c|c|c|c|}
\hline & \multicolumn{8}{|c|}{ Projections } \\
\hline & 2008 & 2009 & 2010 & 2011 & 2012 & 2013 & 2018 & 2028 \\
\hline \multicolumn{9}{|c|}{ NPV of debt-to-GDP ratio } \\
\hline Baseline & 5 & 5 & 6 & 6 & 7 & 7 & 10 & 9 \\
\hline \multicolumn{9}{|l|}{ A. Alternative Scenarios } \\
\hline A1. Key variables at their historical averages in 2009-28 1/ & 5 & 6 & 7 & 8 & 8 & 7 & $\mathbf{0}$ & 0 \\
\hline A2. New public sector loans on less favorable terms in $2009-282 /$ & 5 & 6 & 6 & 7 & 8 & 9 & 13 & 13 \\
\hline \multicolumn{9}{|l|}{ B. Bound Tests } \\
\hline B1. Real GDP growth at historical average minus one standard deviation in $2009-10$ & 5 & 5 & 6 & 6 & 7 & 8 & 11 & 9 \\
\hline B2. Export value growth at historical average minus one standard deviation in 2009-10 3/ & 5 & 6 & 7 & 8 & 8 & 9 & 11 & 9 \\
\hline B3. US dollar GDP deflator at historical average minus one standard deviation in 2009-10 & 5 & 5 & 6 & 7 & 8 & 8 & 11 & 10 \\
\hline B4. Net non-debt creating flows at historical average minus one standard deviation in 2009-10 4/ & 5 & 6 & 8 & 8 & 9 & 9 & 11 & 9 \\
\hline B5. Combination of B1-B4 using one-half standard deviation shocks & 5 & 5 & 5 & 6 & 7 & 7 & 10 & 9 \\
\hline B6. One-time 30 percent nominal depreciation relative to the baseline in 20095 / & 5 & 7 & 8 & 9 & 10 & 11 & 15 & 13 \\
\hline
\end{tabular}

\section{NPV of debt-to-exports ratio}

Baseline

A. Alternative Scenarios

A1. Key variables at their historical averages in 2009-28 1/

A2. New public sector loans on less favorable terms in 2009-28 2

$\begin{array}{rrrrrrrr}16 & 23 & 28 & 32 & 33 & 32 & \mathbf{1} & 0 \\ 16 & 20 & 24 & 30 & 35 & 42 & \mathbf{7 7} & 92\end{array}$

B. Bound Tests

B1. Real GDP growth at historical average minus one standard deviation in 2009-10

B2. Export value growth at historical average minus one standard deviation in 2009-10 3/

B3. US dollar GDP deflator at historical average minus one standard deviation in 2009-10

B4. Net non-debt creating flows at historical average minus one standard deviation in 2009-10 4/

B5. Combination of B1-B4 using one-half standard deviation shocks

B6. One-time 30 percent nominal depreciation relative to the baseline in 2009 5/

NPV of debt-to-revenue ratio

Baseline

A1. Key variables at their historical averages in 2009-28 1

A2. New public sector loans on less favorable terms in 2009-28 2

B. Bound Tests

B1. Real GDP growth at historical average minus one standard deviation in 2009-10

B2. Export value growth at historical average minus one standard deviation in 2009-10 3 /

B3. US dollar GDP deflator at historical average minus one standard deviation in 2009-10

B4. Net non-debt creating flows at historical average minus one standard deviation in 2009-10 4/

B5. Combination of B1-B4 using one-half standard deviation shocks

B6. One-time 30 percent nominal depreciation relative to the baseline in 2009 5/

$\begin{array}{llllllll}22 & 24 & 26 & 30 & 34 & 38 & \mathbf{5 8} & 54 \\ 22 & 26 & 32 & 35 & 39 & 43 & \mathbf{6 0} & 52 \\ 22 & 24 & 28 & 32 & 36 & 40 & \mathbf{6 2} & 57 \\ 22 & 28 & 35 & 39 & 43 & 46 & \mathbf{6 2} & 52 \\ 22 & 24 & 23 & 27 & 32 & 35 & \mathbf{5 6} & 53 \\ 22 & 33 & 36 & 41 & 47 & 52 & \mathbf{7 9} & 73\end{array}$


Table 1b. Cameroon: Sensitivity Analyses for Key Indicators of Public and Publicly Guaranteed External Debt, $2007-27$ (continued)

$$
\text { (In percent) }
$$

\section{Debt service-to-exports ratio}

Baseline

A. Alternative Scenarios

A1. Key variables at their historical averages in 2009-28 1/

A2. New public sector loans on less favorable terms in 2009-28 2/

\section{B. Bound Tests}

B1. Real GDP growth at historical average minus one standard deviation in 2009-10 B2. Export value growth at historical average minus one standard deviation in 2009-10 3/

B3. US dollar GDP deflator at historical average minus one standard deviation in 2009-10

B4. Net non-debt creating flows at historical average minus one standard deviation in 2009-10 4/

B5. Combination of B1-B4 using one-half standard deviation shocks

B6. One-time 30 percent nominal depreciation relative to the baseline in 20095

\section{Debt service-to-revenue ratio}

Baseline

A. Alternative Scenarios

A1. Key variables at their historical averages in 2009-28 1/

A2. New public sector loans on less favorable terms in 2009-28 2/

\section{B. Bound Tests}

B1. Real GDP growth at historical average minus one standard deviation in 2009-10

B2. Export value growth at historical average minus one standard deviation in 2009-10 3/

B3. US dollar GDP deflator at historical average minus one standard deviation in 2009-10

B4. Net non-debt creating flows at historical average minus one standard deviation in 2009-10 4/

B5. Combination of B1-B4 using one-half standard deviation shocks

B6. One-time 30 percent nominal depreciation relative to the baseline in 20095 /

Memorandum item:

Grant element assumed on residual financing (i.e., financing required above baseline) $6 /$

\section{1}

1

1

1

1

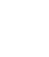

) 
Figure 2. Cameroon: Indicators of Public and Publicly Guaranteed External Debt Under Alternative Scenarios, 2007-2027
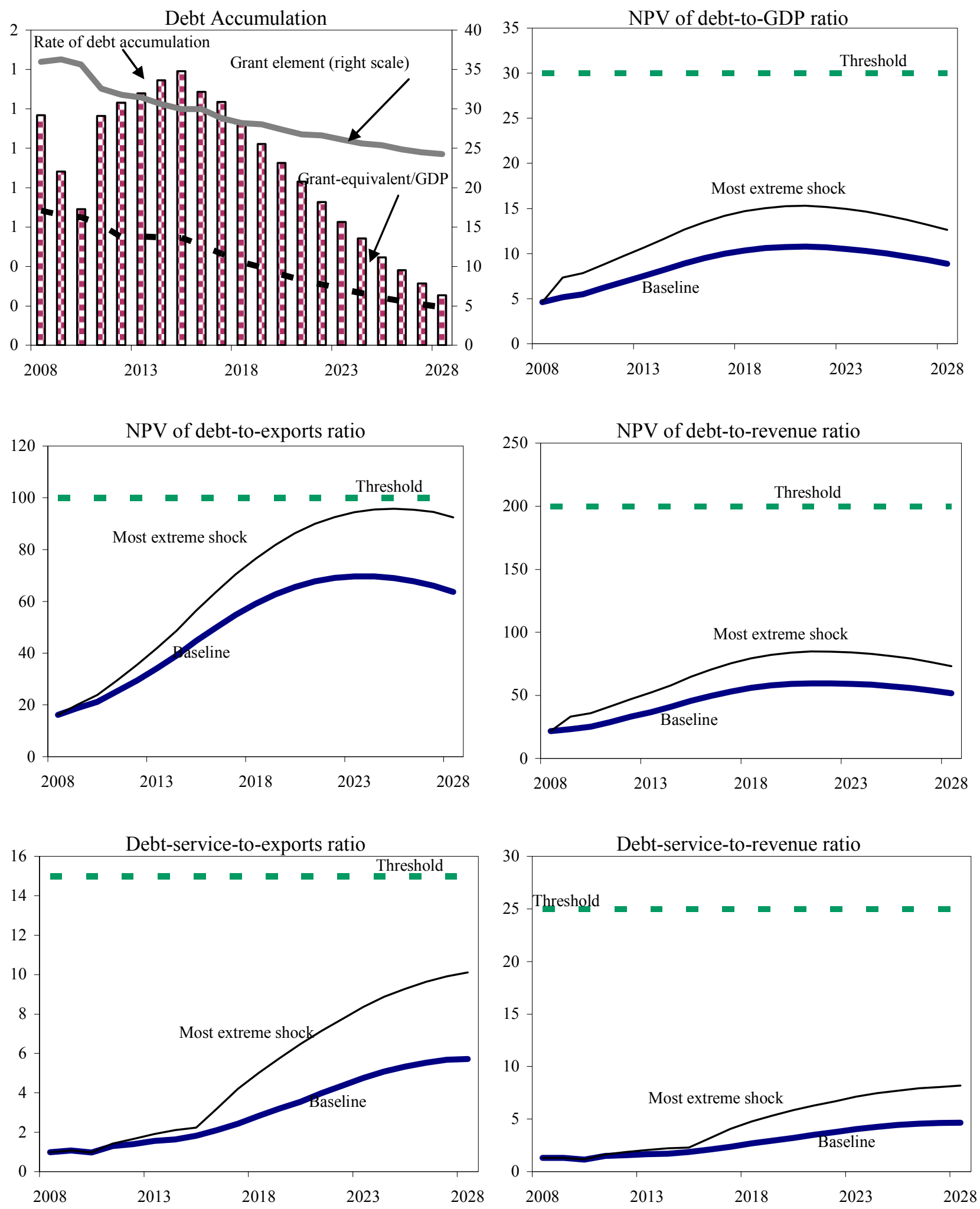

Source: Staff projections and simulations. 
Table 2a. Cameroon: Public Sector Debt Sustainability Framework, Baseline Scenario, 2008-2028 (In percent of GDP, unless otherwise indicated)

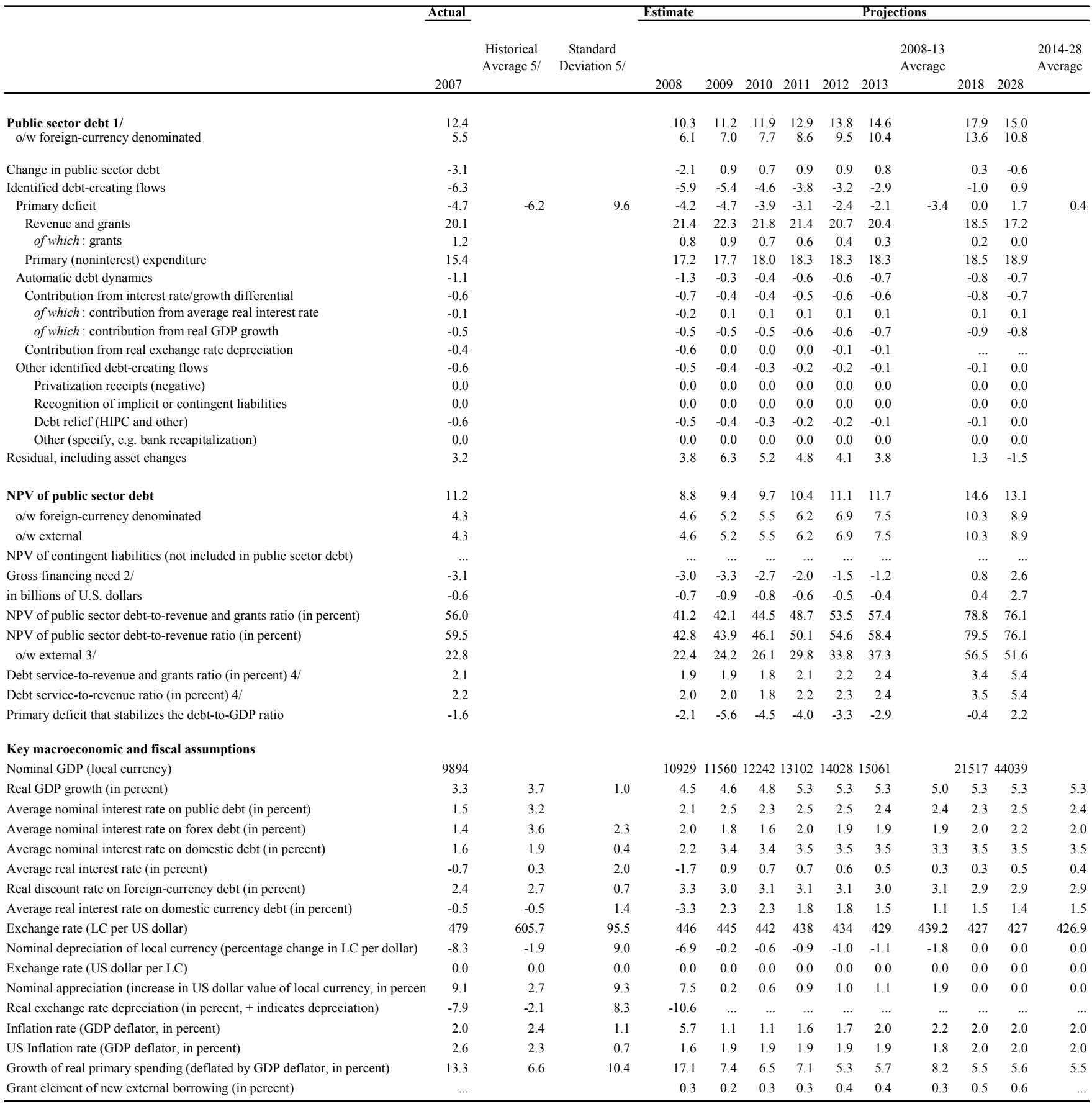

Sources: Country authorities; and Fund staff estimates and projections.

1/ [Indicate coverage of public sector, e.g., general government or nonfinancial public sector. Also whether net or gross debt is used.]

2/ Gross financing need is defined as the primary deficit plus debt service plus the stock of short-term debt at the end of the last period.

3/ Revenues excluding grants.

4/ Debt service is defined as the sum of interest and amortization of medium and long-term debt.

5/ Historical averages and standard deviations are generally derived over the past 10 years, subject to data availability. 
Table 2b. Cameroon: Sensitivity Analysis for Key Indicators of Public Debt 2008-2028

\begin{tabular}{ll}
\hline \\
\hline NPV of Debt-to-GDP Ratio
\end{tabular}

Baseline

\section{A. Alternative scenarios}

A1. Real GDP growth and primary balance are at historical averages

A2. Primary balance is unchanged from 2008

A3. Permanently lower GDP growth 1/

\section{B. Bound tests}

B1. Real GDP growth is at historical average minus one standard deviations in 2009-2010

B2. Primary balance is at historical average minus one standard deviations in 2009-2010

B3. Combination of B1-B2 using one half standard deviation shocks

B4. One-time 30 percent real depreciation in 2009

B5. 10 percent of GDP increase in other debt-creating flows in 2009

\section{NPV of Debt-to-Revenue Ratio 2/}

Baseline

\section{A. Alternative scenarios}

A1. Real GDP growth and primary balance are at historical averages

A2. Primary balance is unchanged from 2008

A3. Permanently lower GDP growth $1 /$

\section{B. Bound tests}

B1. Real GDP growth is at historical average minus one standard deviations in 2009-2010

B2. Primary balance is at historical average minus one standard deviations in 2009-2010

B3. Combination of B1-B2 using one half standard deviation shocks

B4. One-time 30 percent real depreciation in 2009

B5. 10 percent of GDP increase in other debt-creating flows in 2009

Debt Service-to-Revenue Ratio 2/

Baseline

\section{A. Alternative scenarios}

A1. Real GDP growth and primary balance are at historical averages

A2. Primary balance is unchanged from 2008

A3. Permanently lower GDP growth 1/

\section{B. Bound tests}

B1. Real GDP growth is at historical average minus one standard deviations in 2009-2010

B2. Primary balance is at historical average minus one standard deviations in 2009-2010

B3. Combination of B1-B2 using one half standard deviation shocks

B4. One-time 30 percent real depreciation in 2009

B5. 10 percent of GDP increase in other debt-creating flows in 2009

Projections

\begin{tabular}{llllllll}
\multicolumn{8}{c}{ Projections } \\
\hline 2008 & 2009 & 2010 & 2011 & 2012 & 2013 & 2018 & 2028 \\
\hline
\end{tabular}


Figure 3. Cameroon: Indicators of Public Debt Under Alternative Scenarios, 2008-2028 1/

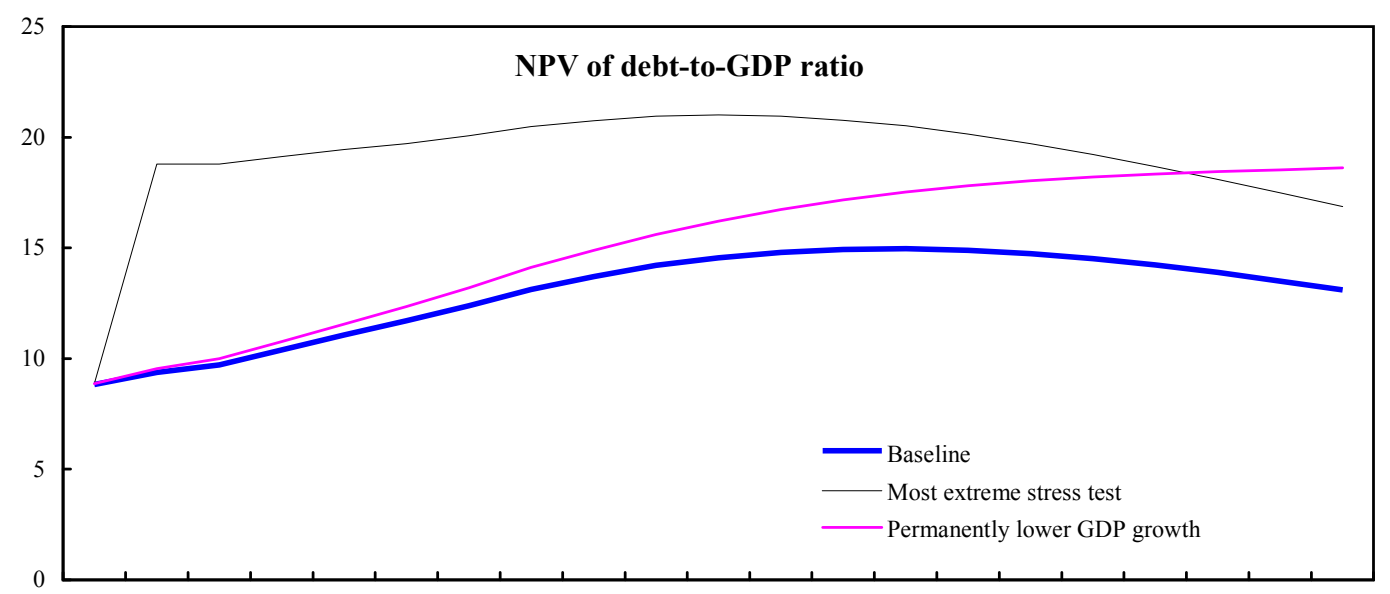

200820092010201120122013201420152016201720182019202020212022202320242025202620272028

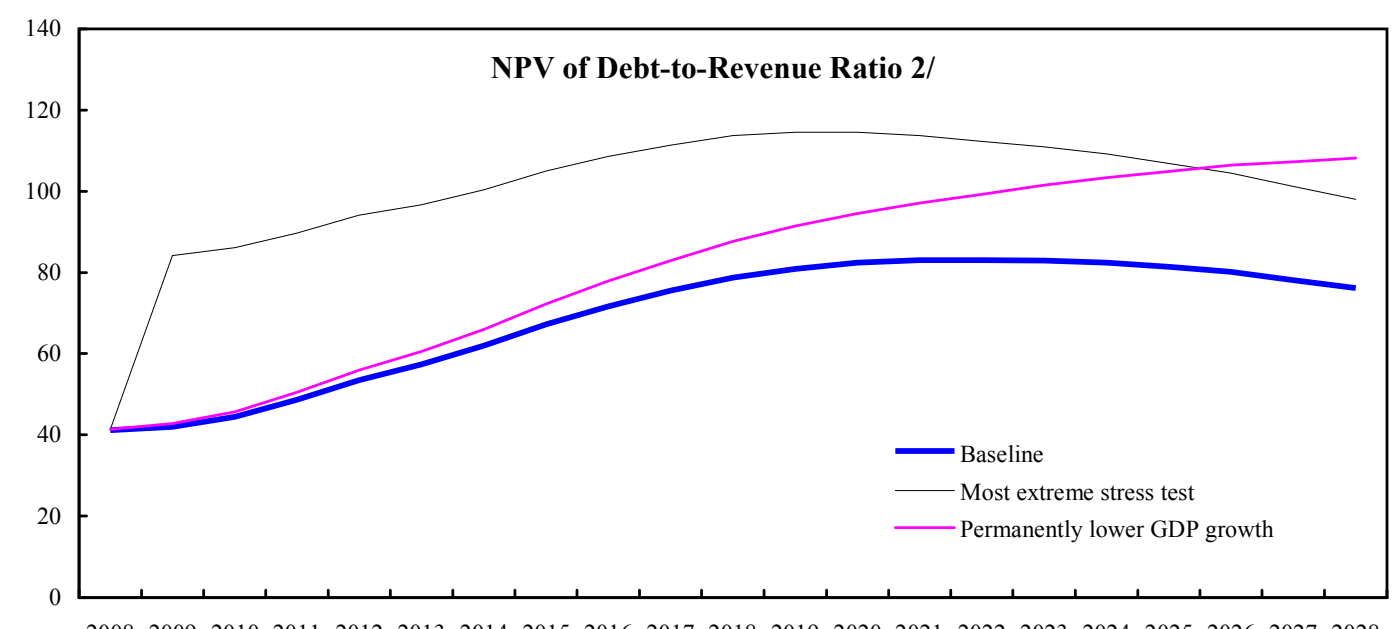

200820092010201120122013201420152016201720182019202020212022202320242025202620272028

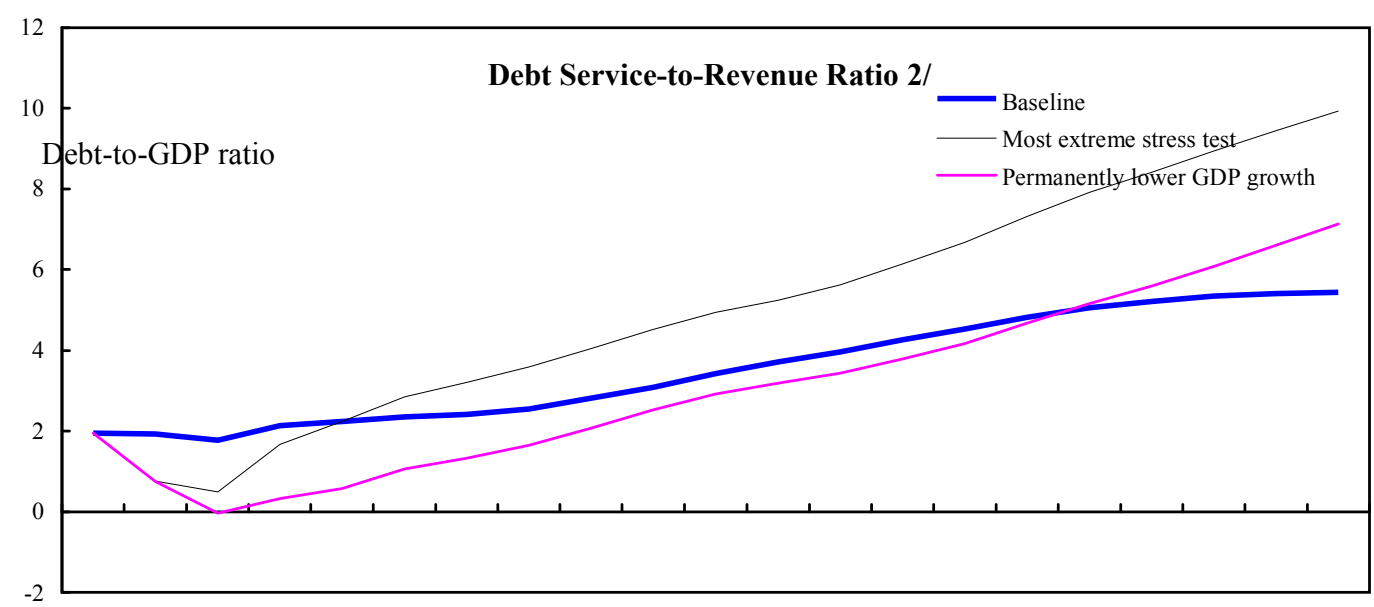

200820092010201120122013201420152016201720182019202020212022202320242025202620272028

Source: Staff projections and simulations.

1/ Most extreme stress test is test that yields highest ratio in 2018.

2/ Revenue including grants. 


\section{Statement by the IMF Staff Representative \\ June 27, 2008}

This statement provides an update on economic developments since the staff report was issued. These developments do not alter the thrust of the staff appraisal.

Inflation continued to increase in the first quarter of 2008, climbing to 5.4 percent (yearon-year) compared with 2.3 percent a year ago. The food price index rose by 10 percent.

$>$ Based on preliminary data, the nonoil primary deficit (program definition) in the first quarter of 2008 was lower by about 0.5 percent of nonoil GDP primarily reflecting lowerthan-expected current and capital spending. A minor shortfall in nonoil revenues was due mainly to lower-than-projected indirect and nontax revenues. Oil revenues fell short of expectations, attributed by the authorities to delays in revenue transfers from the national oil company.

$>$ In line with the March 2008 package of measures, the minimum wage was increased by 20 percent on June 24, 2008.

As part of the privatization program, the national airline, CAMAIR, ceased operations at end-May. The liquidator will maintain a small number of essential personnel to implement the privatization process. 
Press Release No. 08/154

International Monetary Fund

FOR IMMEDIATE RELEASE

Washington, D.C. 20431 USA

June 30, 2008

\section{IMF Executive Board Completes Fifth Review under PRGF Arrangement for Cameroon and Approves US\$4.29 Million Disbursement}

The Executive Board of the International Monetary Fund (IMF) has completed the fifth review of Cameroon's performance under a three-year Poverty Reduction and Growth Facility (PRGF) arrangement. The completion of the review allows for the disbursement of SDR 2.65 million (about US\$4.29 million), which would bring total disbursements under the arrangement to SDR 15.9 million (about US\$25.75 million).

In completing the review, the Board granted a waiver for the non-observance of a performance criterion related to domestic debt, given that the target was missed only by a small margin. The Board also decided to modify the performance criteria to account for the fiscal impact of policies adopted to address the social consequences of rising food prices; and to extend the PRGF arrangement through January 2009.

The three-year PRGF arrangement for Cameroon was approved by the Executive Board on October 24, 2005 (see Press Release No 05/236) in an amount equivalent to SDR 18.57 million (about US\$30.08 million).

Following the Executive Board's discussion, Mr. Takatoshi Kato, Deputy Managing Director and Acting Chair, said:

"The Cameroonian authorities are to be commended for their good fiscal performance and commitment to fiscal sustainability. Implementation of structural measures is also welcome particularly in the area of public finance management.

"The authorities are faced with the difficult challenge of finding an appropriate balance between maintaining a prudent fiscal policy, addressing the social consequences of rising food and fuel prices, and promoting growth through structural reforms and public investment. Their policy course, including the measures adopted in March in response to the social unrest, is consistent with these goals.

"Nonetheless, going forward, it would be important for fuel prices to reflect world market conditions so that consumption could adjust accordingly. Targeted support for vulnerable 
groups would be preferable to generalized subsidies, the latter benefiting more the rich than the poor.

"Furthermore, while the authorities' commitment to contain the budgetary impact of the March 2008 measures is welcome, cuts in spending on goods and services should not jeopardize public services. The authorities should also be vigilant with regard to institutional capacity constraints. In this regard, the authorities' commitment to continue strengthening public expenditure management, and improve project preparation and execution, is welcome.

"Prudent debt management should remain a priority in the post-debt relief period. While the risk of debt distress remains low, borrowing decisions over the medium term should continue to consider carefully project viability and concessionality issues to safeguard debt sustainability.

"Achieving faster growth would require intensified efforts on reform. Mobilizing greater nonoil revenue and reducing subsidies to public enterprises would be critical to create the needed fiscal space for increasing priority spending, including on agriculture and infrastructure. In addition, measures would need to be implemented to improve financial intermediation, trade, and the business environment. In this regard, the authorities' commitment to implement their medium-term action plan to deepen further the financial sector is welcome," Mr. Kato said.

The PRGF is the IMF's concessional facility for low-income countries. PRGF loans carry an annual interest rate of 0.5 percent and are repayable over 10 years with a $5 \frac{1}{2}$-year grace period on principal payments. 


\section{Statement by Laurean W. Rutayisire, Executive Director for Cameroon}

June 27, 2008

On behalf of my Cameroonian authorities, I would like to express my appreciation to the Executive Board and Management for their continued support to Cameroon's efforts towards sustained growth and economic development. I would also like to thank staff for constructive policy dialogue and fruitful exchanges during their recent visit to Yaounde. As has been the case with staff reports on previous reviews, the authorities have expressed their consent to the publication of staff reports on the fourth review. As the program performance in the six-month period to end-December 2007 has been broadly satisfactory, my authorities request the completion of the fifth review under the PRGF arrangement.

\section{RECENT ECONOMIC DEVELOPMENTS}

Soaring oil and food prices and a subsequent transport strike led to violent social unrest that paralyzed economic activity in a number of cities in February 2008. The authorities responded swiftly to these unforeseen events through a series of emergency measures, including raising civil servants' salaries, suspensions or cuts in taxes and customs duties on some consumer goods and a decrease in retail prices of petroleum and the planned recruitment of civil servants to improve the efficiency of the civil service.

It is important to stress that the unrest was contained without disrupting the implementation of the program. To avoid disruptions and ensure the medium-term sustainability of the emergency measures, the government has decided to reallocate appropriations within the budget, accelerate civil service reform, strengthen the mobilization of nonoil revenue, cut expenditure on goods and services without jeopardizing the quality of public service and take any other measures deemed necessary to accommodate for the additional spending, while maintaining fiscal sustainability.

As a result of the continued implementation of sound macroeconomic and structural policies, economic activity picked up in 2007 and external developments were favorable. Nonoil real GDP growth picked up to 3.9 percent from 2.6 percent in 2006 and the 2007 budget surplus was higher than projected. Although broad money recorded an increase due to continued accumulation of net foreign assets and slower pace of accumulation of government deposits in the banking system, inflation continued to decline. The current account also registered a slight surplus. Most quantitative targets for end-December 2007 were met, with the exception of the performance criterion related to domestic debt and the benchmark on nonoil revenues that were missed by small margins. Execution of the capital budget improved significantly compared to 2006, owing to efforts to improve the efficiency of expenditure management.

The planned structural reforms for the period July-December 2007 were completed.

Concerning government finance, the authorities adopted the 2008 Budget Law that was 
consistent with the objectives of the PRGF-supported program and made the single taxpayer identification for large companies more secure. Regarding fuel pricing policy, the authorities adopted a new formula for the automatic adjustment of fuel prices. In the financial sector, transactions involving Treasury-Zero Coupon bonds became possible, the CAMPOST accounts for years 2004 to 2006 were produced, the draft business plan for CAMPOST financial activities was finalized. Public enterprise reform also continued to be implemented. The management contract of the water company (SNEC) was signed, the privatization of the telecommunications company (CAMTEL) is proceeding. The airline company (CAMAIR) was liquidated and a consulting firm was selected for the privatization of the newly created airline entity to replace CAMAIR. As regards governance, the authorities continued implementation of measures to enhance transparency, by publishing the quarterly budget execution reports, the quarterly operating reports of the national oil company (SNH), and the annual financial aggregates of the main public enterprises, as well as the judicial decisions and administrative penalties against government employees. As part of the anti-corruption campaign, the authorities have stepped-up their efforts by arresting two ex-ministers on corruption charges and have made the National Anti-Corruption Commission (CONAC) operational.

\section{ECONOMIC AND FINANCIAL POLICIES IN 2008}

The revised macroeconomic framework reflects government priorities since the February unrest. In the period ahead, the key challenge facing the authorities is to strike the right balance between maintaining fiscal sustainability, addressing the harmful social consequences of rising food and fuel prices and promoting economic growth.

My authorities are determined to address the considerable increase in the cost of living by expanding the production base in favor of agriculture and infrastructure and improving the business climate. The macroeconomic framework assumes the favorable trend in economic activity in 2007 is expected to continue into 2008. Real nonoil GDP growth is projected to be 4.6 percent mainly as a result of the recovery in agricultural and services sectors and the significant increase in public investment. However, rising cost of building materials could hamper economic growth and inflationary pressures could re-emerge in connection with international food prices. While fiscal policy will be somewhat more relaxed over the mediumterm to accommodate the measures recently taken to address the pressing needs of the population in the aftermath of the social unrest, it will remain consistent with macroeconomic stability and fiscal sustainability.

\section{Fiscal policy}

The main budget targets of the 2008 program are part of a medium-term fiscal strategy aimed at creating space for priority outlays while preserving fiscal sustainability. This will be achieved through a gradual increase in nonoil revenues, expanded poverty-related spending and paying down domestic arrears to improve the business environment. In implementing this 
strategy, my authorities will put emphasis on increasing the level and quality of priority expenditure in production sectors and infrastructure to accelerate economic growth, foster domestic agricultural production and combat poverty, while preserving the stability of the macroeconomic framework and fiscal sustainability.

On the revenue side, the mobilization of nonoil revenue remains a key challenge, as the authorities expect a shortfall due to the temporary tax exemptions recently granted for certain basic goods. To meet the revenue targets, the authorities are determined to accelerate implementation of a number of administrative measures. This will include the consolidation of the number of tax centers for small taxpayers, the extension of the number of tax payers covered by the tax centers for medium-sized enterprises, the connection of the information systems of the General Directorate of Taxes and the General Directorate of Customs and continued efforts to adopt measures based on the recommendations of the 2008 IMF technical assistance mission and on the action plan of the fiscal reform commission. The authorities have also set up a government-private sector commission to review domestic and foreign trade taxation and prepare a medium-term tax reform plan to improve the mobilization of nonoil revenues. The authorities also intend to improve the collection of property taxes. To increase forestry revenue, the government will strengthen forestry taxation with the assistance of the World Bank and restore the institutional capacity to monitor and control the sector tax base.

On the expenditure side, the authorities will concentrate their efforts on the priority areas of the PRSP and accelerate public investment, particularly in infrastructure and agriculture, health, and education, while lowering non interest current expenditure. To contain the costs of the March 2008 fiscal measures, the authorities plan to cut spending on goods and services by 0.7 percent of nonoil GDP without jeopardizing services. They will also strengthen their efforts to contain wages and staffing by consolidating the harmonized personnel and payroll records, and preparing a plan to reform the civil service in order to design a more efficient civil service policy, allowing rationalizing of recruitment and a more productive government. These savings will be complemented with efforts to reduce transfers to public enterprises and resume the pass-through of changes in world oil prices to consumers, in order to reduce subsidies in favor of SONARA and use the freed budgetary resources to improve social safety net and increase investment in the priority sectors. To this end, my authorities are committed to resuming implementation of the mechanism for adjusting the retail prices of petroleum products starting in 2009 and phasing out fuel price subsidies. In collaboration with the Fund, my authorities will launch a study to determine ways of implementing this sensitive reform process. In the meantime, they continue to implement measures to strengthen SONARA's financial position and reduce budgetary transfers.

In order to improve public expenditure management, the authorities intend to strengthen the budget reporting system and prepare a government financial operations table (TOFE), in a medium-term, on a payment order basis in collaboration with their technical and financial partners. In the meantime, the authorities have agreed to set a ceiling on the stock of fiscal float 
and are committed to stepping up efforts to further improve the monitoring and management of treasury float. Regarding the use of the oil windfall revenue, the authorities are committed to exclusively financing nonrecurring expenditure, in the following areas: (i) accelerating payments on domestic debt and arrears, (ii) buying back debt by external commercial creditors and, (iii) financing investment in sectors specified in the PRSP, including infrastructure and investment in major sectoral programs, including education, health, rural and urban development.

To achieve fiscal sustainability, my authorities will strengthen external debt management. In this context, they continue to negotiate in good faith with the remaining three commercial creditors, in order to reach an agreement in line with Cameroon's commitment to the Paris Club. To keep the risk of debt distress low, they intend to conduct a prudent debt policy to ensure debt sustainability. To this end, the authorities will finalize preparation of a new comprehensive strategy for public debt management consistent with the macroeconomic framework, the medium-term fiscal debt sustainability objectives.

\section{Structural Reforms}

Improving the business environment is a key component of the reform agenda. In this area, my authorities intend to put emphasis on accelerating growth, in particular by improving the business climate, implementing a one-stop shop for business creation to reduce the time and expense of setting-up a business and finalizing a private sector development strategy by the end of 2008. They will also accelerate the privatization of the remaining state-owned enterprises included in the program to improve competitiveness and lessen the budgetary burden on the economy. Improving governance and enhancing the fight against corruption will also help reduce obstacles to private sector development. In this regard, the authorities will continue publishing corruption-related court decisions and prepare an anti-corruption strategy based on the joint CHOC program (Change Habits-Out WITH Corruption) developed in collaboration with donors. Building on the most recent stepped-up anti-corruption campaign, the authorities will take steps to facilitate the asset disclosure of senior government officials, accelerate efforts to recover embezzled public funds and keep publishing on the internet the summary of the reports monitoring the physical and financial implementation of capital investment projects.

In the financial sector, my authorities are committed to implementing the action plan to strengthen financial intermediation with particular focus on increasing the banking sector's resilience to withstand external shocks, establishing a regional government securities market, strengthening the supervision of microfinance, facilitating access to banking services, improving information on the cost of credit and payment defaults, strengthening the legal framework and diversifying financial instruments. In this regard, the authorities have published the list of accredited microfinance institutions to better protect depositors and launched a number of initiatives to facilitate access to credit by reducing constraints linked to the business 
environment. My authorities also intend to work with the Bank of Central African States (BEAC) to update the list of clients in default of liquidated or restructured banks in the central credit register. To promote transparency in the banking sector, my authorities intend to ask BEAC to request that credit institutions publish their lending rates. To improve the soundness of the banking sector and develop the securities market, my authorities will adopt an appropriate regulatory framework for factoring, leasing and venture capital, modify the legislation on the opening and closing of bank branches by end-December 2008 and limit the recourse to new statutory advances from the Central Bank and issue publicly-traded government securities. They are also assessing the future financial activities of CAMPOST.

On regional integration, the authorities will increase coordination with their CEMAC partners in order to provide a new impetus to institutional reforms and consolidate subregional integration. In particular, they bolster efforts to reduce obstacles to the development of intraregional trade, contain and reduce exemptions, eliminate the minimum administrative values for all imported products, implement the Common External Tariff (CET), and to find a common ground with their partners to finalize the Economic Partnership Agreement (EPA) with the European Union. To facilitate foreign trade transactions, the authorities will finalize the implementation of a one-stop shop interface between those parties involved in port transactions.

\section{CONCLUSION}

My Cameroonian authorities continue to implement the PRGF-supported program in a satisfactory manner in spite of a difficult domestic and international environment. They have achieved significant progress in the implementation of reforms, thanks to strong commitment to macroeconomic stability and fiscal sustainability stemming from good ownership of the program..

Based on their track record of policy and reform implementation, I would like, on behalf on my authorities, to request the completion of the fifth review under the current PRGF arrangement. In light of the appropriate debt policies pursued by my authorities, including prudent borrowing policies and their good-faith efforts to reach agreements with the remaining three private creditors, I also request the Board's support for the completion of the financing assurances review. My authorities also seek a waiver for the nonobservance of the performance criterion related to domestic debt, whose target was only missed by a small margin. Given the fact that emergency fiscal measures were due to circumstances outside the authorities' control, my authorities would like to request the modification of the June performance criteria to account for the fiscal impact of the emergency measures adopted to address the consequences of rising food and fuel prices. In order to allow time for the completion of the sixth and final review of the current arrangement, the authorities would like to request the extension of the PRGF arrangement through January 2009. On behalf of my authorities, I would appreciate Board support of these requests. 